\title{
PLANEJANDO UMA REDE ESCOLAR MUNICIPAL PARA REDUZIR CUSTOS DE DESLOCAMENTOS
}

\author{
Nadja Glheuca da Silva Dutra
}

Dissertação apresentada à Escola de Engenharia de São Carlos da Universidade de São Paulo como parte dos requisitos para obtenção do título de Mestra em Transportes

ORIENTADOR: Prof. Dr. Antônio Nélson Rodrigues da Silva

São Carlos

1998 
Ficha catalográfica preparada pela Seção de Tratamento da Informação do Serviço de Biblioteca - EESC-USP

Dutra, Nadja Glheuca da Silva

D978p Planejando uma rede escolar municipal para reduzir custos de deslocamentos / Nadja Glheuca da Silva Dutra. -- São Carlos, 1998.

Dissertação (Mestrado) -- Escola de Engenharia de São Carlos-Universidade de São Paulo, 1998. Área: Transportes.

Orientador: Prof. Dr. Antônio Nélson Rodrigues da Silva.

1. Custo de transporte. 2. Planejamento urbano. 3. Escolas. I. Título 
À minha mãe, meu eterno bem 
Meus sinceros agradecimentos

Ao Prof. Antônio Nélson, pela orientação dada durante a elaboração deste trabalho.

À Coordenadoria de Aperfeiçoamento de Pessoal e Nível Superior (CAPES), pela bolsa de estudo concedida.

À Secretaria Municipal de Educação de São Carlos, representada por Nilson Passoni, pela atenção dispensada com a cessão dos dados das escolas municipais.

À Delegacia de Ensino do Município de São Carlos, na pessoa de Maria Auxiliadora Pinto Schiavone (Dora) que, muito carinhosamente, dispôs-se a me ajudar com os dados de todas as escolas.

Ao Ramez Atique pelo empréstimo do material bibliográfico do $3^{\circ}$ Capítulo.

Aos professores Marta Bastos e Felipe Loureiro do Departamento de Engenharia de Transportes (DET) da Universidade Federal do Ceará pelo incentivo e ajuda.

À Da. Maria (Lucilene) e à Japinha (Simone) pelo companheirismo, amizade e afeto (VALEU!!!).

Ao Marcelo Luna pelo cuidado e pelo empréstimo do micro.

À minha família que, mesmo distante, mostrava-se presente, dando-me apoio e incentivo em todos os momentos.

E, como não poderia deixar de sê-lo, o meu mais que obrigada ao meu bom Deus pela vida e oportunidade concedida e por sua mão sempre estendida. Como Davi, também posso dizer: "Bendiz, ó minha alma, ao Senhor, e tudo o que há em mim bendiga ao seu santo nome; bendiz, ó minha alma ao Senhor, e não te esqueças de nenhum só de seus benefícios". 


\section{SUMÁRIO}

LISTA DE FIGURAS........................................................................................ ix

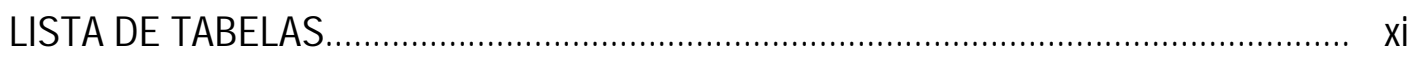

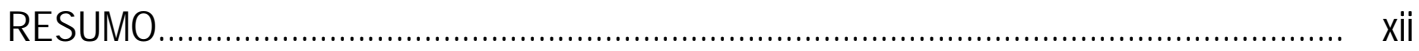

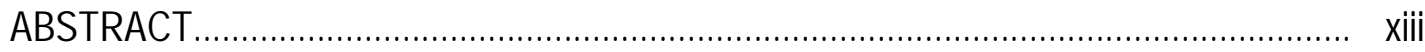

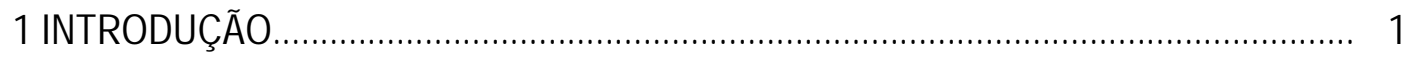

1.1 Justificativa do Trabalho................................................................................ 1

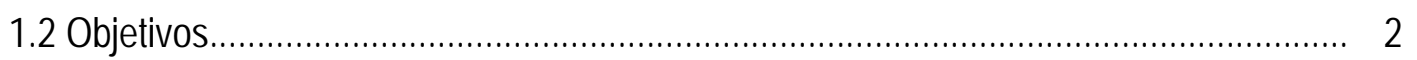

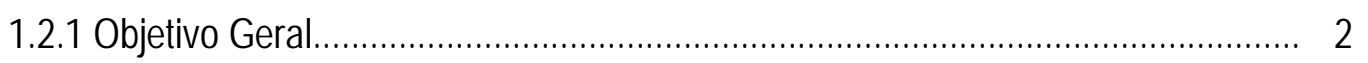

1.2.2 Objetivos Específicos............................................................................... 3

1.3 Apresentação do Trabalho ....................................................................................... 3

2 A EDUCAÇÃO NO BRASIL.......................................................................... 5

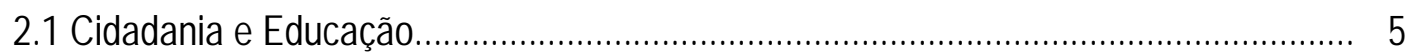

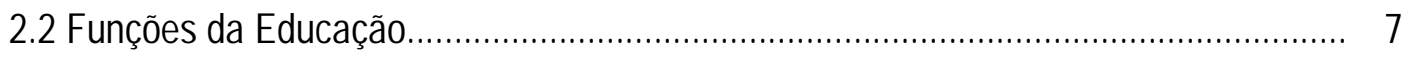

2.3 Sistema Educacional Brasileiro ................................................................... 8

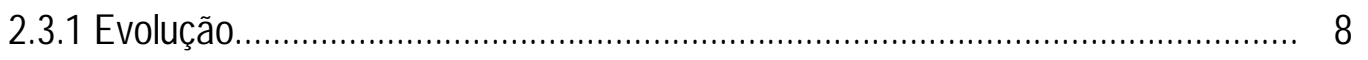

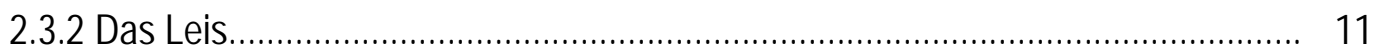

2.3.3 Municipalização da Rede de Ensino............................................................. 12

2.3.4 Investimentos na Educação ..................................................................... 14

2.3.5 Fatores que Influem na Escolaridade da População.......................................... 15

2.3.6 Democratização e Qualidade no Ensino........................................................ 15

2.4 Reorganização Escolar..................................................................................... 16

2.4.1 Breve Histórico.................................................................................... 17

2.4.2 Objetivos da Reorganização Escolar............................................................ 17

2.4.3 Procedimentos Adotados pela Reorganização................................................. 18

2.4.4 Alguns Resultados da Reorganização........................................................... 20

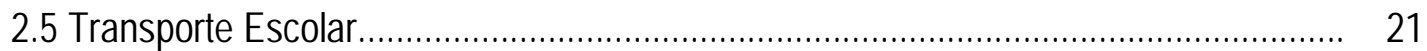




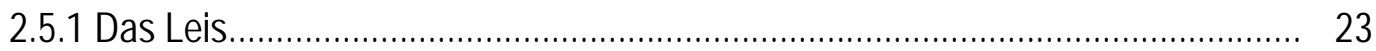

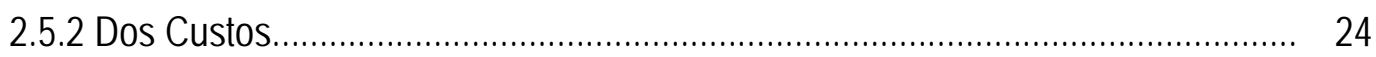

3 SISTEMAS DE INFORMAÇÕES GEOGRÁFICAS (SIGS) ....................................... 26

3.1 Introdução aos SIGs........................................................................................ 26

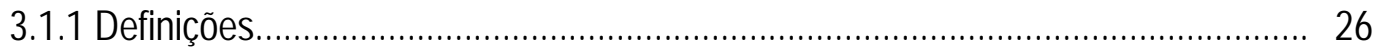

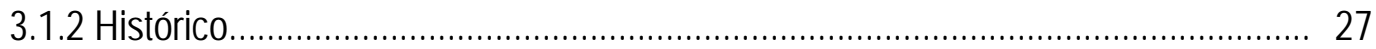

3.1.3 Espaço Geográfico e Ambiente Computacional............................................... 29

3.1.4 Algumas Funções e Vantagens dos SIGs....................................................... 31

3.1.5 Conceitos Básicos........................................................................... 32

3.1.6 Fontes de Dados e Estruturas de Representação............................................. 33

3.1.7 Diferenças entre Algumas Terminologias Empregadas...................................... 37

3.2 Estratégias de Implantação e Aplicações de um SIG................................................. 38

3.3 SIGs e Planejamento Urbano ................................................................................ 39

3.3.1 Cadastro e SIGs..................................................................................... 41

3.3.2 SIGs na Localização de Instalações.................................................................. 42

3.4 Sistemas de Informações Geográficas Aplicados aos Transportes (SIGs-T).............. 45

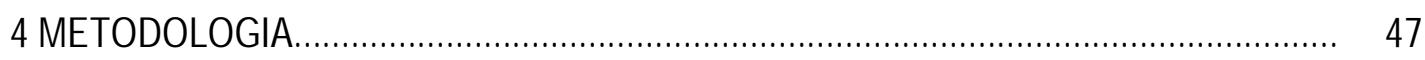

4.1 Abordagens do Trabalho............................................................................... 47

4.2 Obtenção dos Dados................................................................................ $\quad 50$

4.2.1 Justificativa para os Dados Empregados......................................................... 52

4.3 Software e Recursos do Software Empregados..................................................... 53

4.4 Método a Ser Aplicado na Pesquisa (Sumário de Atividades)................................... 60

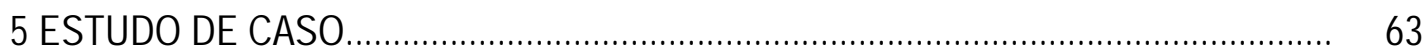

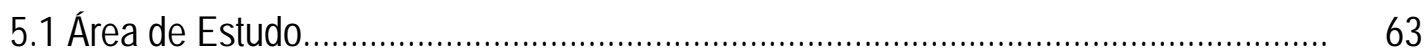

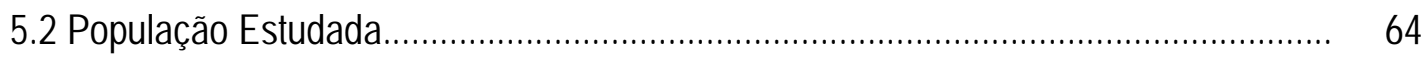

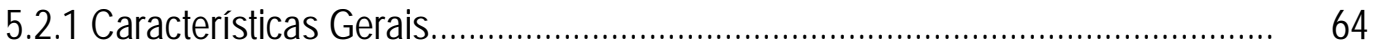

5.2.2 Características da Reorganização Escolar na Rede Estadual de Ensino........... 65

5.2.3 Características da Rede Municipal de Ensino................................................. 67

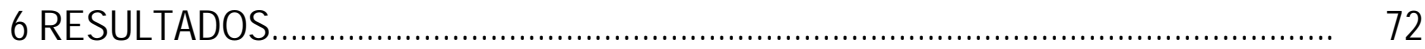

6.1 Resultado da Rotina de Modelos de Fluxo em rede............................................... 72

6.2 Resultados das Rotinas de Agrupamento e Particionamento.................................... 74

6.3 Resultados da Rotina de Localização de Instalações............................................. 77 
6.4 Análise dos Resultados......

84

7 CONCLUSÕES E RECOMENDAÇÕES

REFERÊNCIAS BIBLIOGRÁFICAS.

ANEXOS

APÊNDICE 


\section{LISTA DE FIGURAS}

FIGURA 3.1 - Evolução do Pensamento Geográfico como Ciência Humana.................... 27

FIGURA 3.2 - Transformações Conceituais ............................................................. 30

FIGURA 3.3 - Transformações Conceituais: do Mundo Real ao Mundo Digital................. 31

FIGURA 3.4 - Arquitetura de Sistemas de Informações Geográficas.............................. 34

FIGURA 3.5 - Forma de Representação de Dados....................................................... 36

FIGURA 4.1 - Divisão Setorial do IBGE com Respectivos Centróides............................ 48

FIGURA 4.2 - Conceitos de Contigüidade e Compacidade............................................ 56

FIGURA 5.1 - Localização Geográfica do Município de São Carlos................................. 64

FIGURA 5.2 - Distribuição Espacial das Escolas Públicas, com Séries de 1a à $4^{\mathrm{a}}$ Situação Anterior e Posterior ̀̀ Reforma Escolar de 1995.......................... 66

FIGURA 5.3 - Setores Censitários que Contém a Amostra de 109 Alunos da

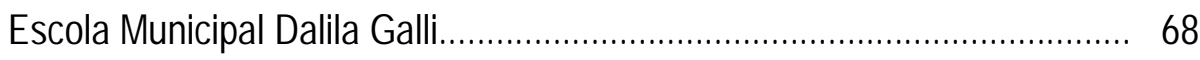

FIGURA 5.4 - Setores Censitários que Contém a Amostra de 154 Alunos da

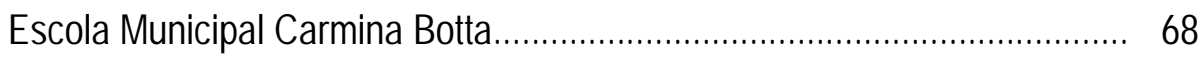

FIGURA 5.5 - Mapa Temático da Variável de no 96 do IBGE -

"Crianças de 0 a 4 Anos"......................................................................... 71

FIGURA 6.1 - Comparação do Custos de Deslocamento Antes e Após

a Reforma Escolar.

FIGURA 6.2 - Comparação do Custos Acumulados de Deslocamento

Antes e Após a Reforma Escolar......

FIGURA 6.3 - Agrupamento dos Centróides, Baseados na Variável no 96 do IBGE

(Crianças de 0 a 4 Anos) .................................................................... 74

FIGURA 6.4 - Visualização das "Sementes" Geradas pela Rotina de

Agrupamento, na Camada de Áreas..................................................... 75

FIGURA 6.5 - Pontos Iniciais Adotados no Particionamento.......................................... 76

FIGURA 6.6 - Distritamento do Setores Censitários em 18 Zonas.................................. 77 
FIGURA 6.7 - Identificação da Instalações Escolares Antes e Após a Reorganização Escolar..

FIGURA 6.8 - Escolha da Melhor Alternativa de Localização.

Escolas Candidatas: 10 e 11 80

FIGURA 6.9 - Escolha da Melhor Alternativa de Localização.

Escolas Candidatas: 8 e 9.

FIGURA 6.10 - Cenário Hipotético - Escolha de Duas Melhores Instalações dentre Cinco Candidatas.

FIGURA 6.11 - Cenário Hipotético - Escolha da Melhor Instalação dentre Cinco Candidatas. 


\section{LISTA DE TABELAS}

TABELA 2.1 - Impactos do Transporte na Escolarização da Crianças Rurais................... 22

TABELA 2.2 - Estudantes Transportados Segundo o Meio de Transporte....................... 24

TABELA 3.1 - Vantagens e Desvantagens dos Formatos Raster e Vetorial.................... 36

TABELA 4.1 - Base de Dados de Endereços.............................................................. 51

TABELA 4.2 - Diferenças entre as Rotinas de Particionamento e Agrupamento.............. 56

TABELA 4.3 - Rotinas Mencionadas no Método com Aplicações Práticas....................... 59

TABELA 6.1 - Análise de Sensibilidade dos Deslocamentos na Construção das Novas Instalções (Cenário Hipotético).............................................. 84 


\section{RESUMO}

DUTRA, N. G. da S. (1998). Planejando uma Rede Escolar Municipal para Reduzir Custos de Deslocamentos. São Carlos, 1998. 93 p. Dissertação (Mestrado) -- Escola de Engenharia de São Carlos, Universidade de São Paulo.

Este trabalho visa definir possíveis arranjos de localização de escolas de primeiro grau, situadas na cidade de São Carlos, analisando-se os custos de deslocamento casa-escola. Neste estudo, serão abordados os custos de deslocamentos decorrentes de uma reforma escolar, presenciada no Estado de São Paulo. Segundo esta reforma, os alunos de primeiro grau menor ( $1^{\mathrm{a}}$ a $4^{\mathrm{a}}$ séries) ficaram separados fisicamente dos demais níveis. Tal separação visou a melhorias na qualidade de ensino, com conseqüente diminuição de desperdício de recursos financeiros. Este estudo se utiliza dos Sistemas de Informações Geográficas como ferramenta capaz de gerar e analisar estes custos, comparando-se o que se tinha antes da reforma, o que se tem hoje, e o que se poderia ter quando da aplicação de um planejamento orientado por este ferramental. Para se procederem a estas análises, foram criados cenários (alguns deles hipotéticos) que permitiram simulações, as quais tinham o objetivo principal de apontar a melhor solução (ou melhores soluções) para o sistema, com conseqüente diminuição do custo médio de deslocamento. Os resultados encontrados indicam que 0 método proposto pode auxiliar as autoridades competentes na definição de localização para novas escolas ou na realocação de matrículas, de forma a melhor atender à comunidade, objetivando a redução de custos de deslocamentos.

Palavras-chave: custos de transportes, planejamento urbano, escolas. 


\begin{abstract}
DUTRA, N. G. da S. (1998). Planning the Distribution of Schools in an Urban Area for Reducing Travel Costs. São Carlos, 1998. 93 p. Dissertação (Mestrado) - Escola de Engenharia de São Carlos, Universidade de São Paulo.
\end{abstract}

The main aim of this work is to analyze alternative locations for a specific set of schools in the city of São Carlos, always trying to reduce travel costs from home to school. This study evaluates the impact of the changes resulting from the reorganization of the education system in the State of São Paulo on the students trip patterns. In this reorganization process, the students of $1^{\text {st }}$ to $4^{\text {th }}$ grades have been physically separated from the older ones. This division was done to improve the learning process, with a consequent reduction of the costs caused by students failures. This study uses a Geographical Information System as a tool to calculate and to analyze travel costs before and after the reorganization, as well as in some scenarios planned with its built-in procedures. Several simulations, with both real and hypothetical scenarios, were used in the search for the best solution (or solutions) for the system - the one (ones) which minimizes the average travel costs. The results found clearly indicate that the proposed method can serve as a guideline to the authorities in the definition of the location of new schools or relocation of students, reducing travel costs in both cases.

Keywords: transportation costs, planning urban, schools. 


\section{CAPÍTULO 1}

\section{INTRODUÇÃO}

\subsection{Justificativa do Trabalho}

O rápido crescimento das cidades brasileiras, não acompanhado de um planejamento prévio de expansão (delimitando o uso e a ocupação do solo), vem acarretando transtornos à comunidade no que se refere aos deslocamentos, visto que estes se tornam cada vez maiores. Devido a isso, torna-se necessário um conhecimento das demarcações das áreas do município, tipos de serviços atualmente prestados à comunidade em cada área, sua abrangência e múltiplos aspectos ligados às mesmas. Este conhecimento tornará possível, em futuro bem próximo, a construção ordenada e integrada de instalações, que melhor atendam à mesma comunidade. 0 presente trabalho se delimitará ao fator de distribuição espacial de um desses serviços (a rede escolar), levando-se em consideração os custos de deslocamento (distâncias percorridas) por uma determinada classe de demanda. Serão desconsiderados outros tipos de custos, tais como o monetário, de conveniência, de satisfação, de eficiência no ensino, dentre outros, os quais apresentam diferentes conotações para diferentes tipos de demanda. Este trabalho se deterá aos deslocamentos decorrentes do trajeto "casa-escola" de uma parcela da classe estudantil. Será desenvolvido um estudo de caso, tendo como base a área urbana do Município de São Carlos (SP), que, apesar de ser uma cidade de médio porte, já enfrenta problemas de deslocamentos da população.

A partir da Constituição de 1988, as educações infantil e de $1^{0}$ grau passaram a ser gerenciadas pelo município. Também por força de lei, todo município é obrigado a ter planos diretores (ou plano de diretrizes e metas) que atentem às prioridades previstas (educação, saúde, habitação e transportes). Baseando-se nisto, esse trabalho busca um comparativo 
entre o que determina a legislação, o que de fato existe e o que se teria quando da utilização de tecnologias modernas na escolha de melhores alternativas de localização das escolas.

Neste trabalho, será feita a análise comparativa das mudanças nos deslocamentos dos estudantes, decorrentes de uma reorganização escolar - presenciada no Estado de São Paulo - segundo a qual foram separados os alunos de primeiro grau menor ( $1^{\mathrm{a}}$ a $4^{\mathrm{a}}$ séries) dos demais níveis. Tal separação visou a melhorias na qualidade de ensino, com conseqüente diminuição de desperdício de recursos financeiros, estimado em US\$600 milhões/ano, advindos da repetência anual.

Para a consecução deste trabalho, foi necessário a formação de um cadastro de endereços da referida cidade, contendo informações da demanda e da oferta analisadas. 0 software escolhido para reproduzir esta base de dados foi um SIG-T (Sistema de Informações Geográficas aplicado aos Transportes) que, além de servir como um grande banco de dados, também possui rotinas desenvolvidas especificamente para a área de planejamento em transportes. Este ferramental também é capaz de gerar e analisar os custos de deslocamento envolvidos antes e após a reforma escolar, verificando-se, por meio de simulações, quais as atitudes mais ou menos coerentes na realocação destes serviços diante da demanda servida. Este trabalho também apresenta, por meio de simulações, melhores arranjos de distribuição destas escolas, de forma a melhor atender à demanda.

\subsection{Objetivos}

\subsubsection{Objetivo Geral}

- Planejar a distribuição das escolas em uma área urbana de maneira a minimizar custos de deslocamentos. 


\subsubsection{Objetivos Específicos}

- Analisar a presente distribuição de escolas de primeiro grau menor, definindo (por meio de simulações) possíveis arranjos desta no contexto urbano da área em estudo;

- Analisar os custos de deslocamento decorrentes da reforma escolar.

\subsection{Apresentação do Trabalho}

Esta obra está dividida em sete capítulos, dos quais a corrente Introdução também faz parte (primeiro capítulo). O conteúdo dos capítulos que se seguem é mostrado, resumidamente, nos parágrafos seguintes.

O segundo e terceiro capítulos dizem respeito à revisão bibliográfica feita. $\mathrm{O}$ segundo capítulo, que trata dos Sistemas de Informações Geográficas, dá uma visão geral do que venham a ser estes sistemas. Inicialmente, faz-se uma breve introdução, descrevendo-se os SIGs no tempo e espaço históricos. O capítulo prossegue com conceitos de representações computacionais, mostrando as transformações conceituais do mundo real ao mundo digital. Também são apresentadas as principais funções e vantagens dos SIGs, contextualizando-as ao setor transportes. Em seguida, o capítulo aborda as principais estruturas de representação existentes para estes sistemas, descrevendo as vantagens e desvantagens das representações básicas. Para dirimir dúvidas de terminologias, são apresentados alguns conceitos. O capítulo vai abordando os SIGs de forma a mostrar seus usos e aplicações, definindo os tipos de atividades e decisões que podem envolvê-los no planejamento urbano. Por este trabalho tratar de localização de instalações, apresentam-se alguns exemplos de aplicações dos SIGs envolvendo este tipo de questão. Encerra-se o capítulo com a abordagem feita aos SIGs nos Transportes (SIGs-T).

Dando continuidade ao embasamento teórico, o terceiro capítulo aborda o sistema educacional brasileiro. Neste capítulo, serão vistos conceitos gerais de educação e sua ligação à cidadania, apresentando-se o lado legal. Este capítulo aborda a educação, dandoIhe sua evolução histórica, indo desde o descobrimento do Brasil até os dias atuais. Em 
seguida, será tratada a questão da Municipalização do Ensino, comentando-se os principais objetivos e procedimentos adotados na Reorganização Escolar de 1995. O capítulo é concluído com a abordagem dada ao transporte escolar, apresentando-se as leis que 0 regem e alguns exemplos de medidas adotadas por alguns municípios brasileiros para minimizar problemas com os custos deste setor.

O Capítulo 4 expõe 0 método empregado nesta pesquisa, mostrando-se os procedimentos e medidas adotados no emprego dos dados, posteriormente justificando seu uso. Em seguida, descrevem-se os recursos empregados na pesquisa, apresentando-se definições úteis na compreensão de medidas adotadas por estes. Em seguida, são mostrados exemplos práticos - para melhor compreensão - de cada um destes recursos. 0 capítulo termina com a descrição sumária do método, citando cada procedimento seguido.

O Capítulo 5 relata o caso estudado. Inicialmente, faz-se a descrição da área de estudo. Em seguida, descrevem-se as características da população analisada. Conclui-se 0 capítulo com a aplicação do método, descrevendo-se os procedimentos e medidas adotados neste estudo de caso.

No Capítulo 6, mostram-se os resultados obtidos com a aplicação do método no estudo de caso. Para a melhor percepção deste resultados, estes também são dados graficamente, através de gráficos de freqüência e de mapas. Descrevem-se as simulações feitas, discutindo seus resultados na parte final deste capítulo.

O trabalho se encerra no sétimo e último capítulo, apresentando as conclusões do estudo, seguidas das recomendações propostas. 
CAPÍTULO 2

\section{A EDUCAÇÃO NO BRASIL}

Este capítulo aborda a questão da educação brasileira e sua evolução do ponto de vista ideológico e legal. Também aborda a questão da municipalização do setor escolar, voltando-se mais especificamente para o exemplo do estado de São Paulo, onde se mostra a reformulação educacional vivida desde 1996, seus objetivos e alguns resultados já obtidos. Para concluir, apresentase a questão do transporte escolar.

\subsection{Cidadania e Educação}

Só existe uma fórmula para a manutenção da democracia: sua prática, a qual oferece os mecanismos de defesa e de aperfeiçoamento, que permitem sua consolidação, tornando-a irreversível. Sua prática a faz forte e garante sua contínua evolução. "O direito à informação é, pois, pressuposto da cidadania" (COVAS, 1996).

Cidadania é:

"A qualidade ou estado de cidadão, um indivíduo no gozo dos direitos civis e políticos de um Estado, ou no desempenho de seus deveres para com este".(DICIONÁRIO AURÉLIO, 1993)

"...algo a ser vivido numa sociedade democrática na qual o homem é chamado a participar.” (PAIVA, 1993, p. 10).

“...um estado de espírito e uma postura permanente que levam pessoas a agirem, individualmente ou em grupo, com objetivos de defesa de direitos e de cumprimentos de direitos civis." (RESENDE, 1993, p.10). 
MIZUKAMI (1986) 1 parte do pressuposto de que o Brasil possui cinco abordagens de ensino (tradicional, comportamentalista, humanista, cognitivista e sociocultural) e, para cada uma, faz a inserção de Educação e Escola:

i) Segundo a abordagem tradicional, a Educação é um produto de modelos preestabelecidos, onde as decisões são verticalizadas. A Escola é o lugar onde a educação se realiza e se restringe às informações de sala de aula. Por ter o papel de ajustar 0 indivíduo à sociedade tal como é, a educação garante a continuidade das idéias, sem rupturas ou crises;

ii) Do ponto de vista comportamentalista, a educação é vista como sendo o ato de transmitir conhecimentos, bem como comportamentos éticos, práticas sociais e habilidades, consideradas básicas para a manipulação e controle do meio ambiente sociocultural, tendo por finalidade básica a promoção de mudanças no indivíduo, as quais se referem tanto à aquisição, como à modificação dos comportamentos já existentes. A Escola é considerada uma agência educacional, conservando ou modificando os padrões de comportamento úteis à sociedade;

iii) A abordagem humanista trata da educação do homem, e não apenas da pessoa em situação escolar, tendo como primeira finalidade a criação de condições que facilitem a aprendizagem. Tem como características a autodescoberta e a autodeterminação. Aqui, a Escola oferece condições para que a criança desenvolva seu "processo de vir a ser";

iv) A Educação, do ponto de vista cognitivista, tem por objetivo fazer com que 0 aluno aprenda por si próprio e conquiste a verdade (desenvolvendo o raciocínio e provocando a busca de soluções). É tida por condição necessária ao desenvolvimento natural do ser humano. Inicialmente, a Escola teria a função de ensinar ao aluno a observar, possibilitando, posteriormente, o desenvolvimento de suas potencialidades de ação motora, verbal e mental, com 0 intuito de que este, mais tarde, venha a intervir na sociedade, inovando-a;

1 apud MALLIO (1992) 
v) Finalmente, a abordagem sociocultural põe o homem como sujeito transformador e libertador. A Educação assume caráter amplo, não restrita à Escola nem a um processo formal de educação. É dada como um ato político, onde o conhecimento é posto de forma contínua, não sendo, simplesmente, a transmissão de conteúdos e programas. Nesse contexto, a Escola é considerada como um local possível de um crescimento mútuo, entre professores e alunos.

"...educar o homem é fazê-lo passar do estado de natureza para estado de cultura" (RODRIGUES, 1992, p. 112)

\subsection{Funções da Educação}

i) habilitar os indivíduos para a vida social na medida e proporção de seus valores intrínsecos (CUNHA, 1975²).

Por LUCKESI (1992):

ii) Ajudar a criança a viver num mundo que se transforma em ritmo sem precedente histórico, tornando-a capaz de criar o futuro e de inventar possibilidades inéditas;

iii) orientar o educando à pesquisa e à descoberta de novos projetos e

iv) fornecer os recursos e tecnologias necessários ao desenvolvimento das atividades escolares.

Uma função negativa é apontada por RODRIGUES (1975) ${ }^{3}$ em seu trabalho, o qual afirma que "a Escola tem exercido a função doutrinadora e realizadora das políticas educacionais voltadas para a expansão do capitalismo industrial no Brasil".

2 apud V. MALLIO \& PALMA FILHO (1992) 


\subsection{Sistema Educacional Brasileiro}

\subsubsection{Evolução}

SEVERINO (1986) ${ }^{4}$ afirma que as várias etapas da educação brasileira refletiram 0 contexto ideológico predominante. Segundo este autor, em toda a história da educação brasileira, a política educacional sempre esteve voltada para os interesses particulares das classes dominantes, servindo, desta forma, como força reprodutiva da organização social vigente em cada momento.

Durante o período de 1500 a 1889, a educação sofreu o predomínio da Ideologia Católica. Inicialmente, com as atividades educacionais confiadas à Companhia de Jesus, logo após o início do processo de colonização da terra brasileira. Esta ideologia serviu tanto aos objetivos do Estado colonial quanto aos do Estado imperial (em 1548, constava diretriz política para a colônia que se referia à conversão dos índios ao Catolicismo pela catequese e pela instrução). Ampliada e desvirtuada, a educação jesuítica começou por fazer distinção entre os educandos indígenas e os filhos de portugueses (a instrução passou a ser dada aos colonizadores e a catequese, aos indígenas). Até então, a educação foi financiada por "dotação real", onde o dinheiro, além de chegar atrasado, era insuficiente para manter os custos. Esse monopólio educacional apenas foi extinto em 1759, quando Marquês de Pombal assume o governo português e rompe com os jesuítas, expulsando-os. Mesmo com teor de modernidade em relação à educação da elite colonial, as reformas pombalinas não conseguiram mudar a essência da educação (SEVERINO, 19865; MONLEAVADE, 19896; e AZANHA, 1992).

Após a transferência da família real para o Brasil, em 1808, e a declaração da independência, em 1822, é que algumas mudanças na esfera educacional puderam ser observadas, sobretudo no ensino superior - nada, porém, muito significativo, pois, ainda que voltado para a elite, o ensino continuava precário. Isso é atribuído como reflexo de uma

\footnotetext{
${ }^{3}$ apud MALLIO \& PALMA FILHO (1992)

${ }^{4}$ apud PALMA FILHO (1992)

5 apud PALMA FILHO (1992)

${ }^{6}$ apud APEOESP (1989)
} 
dependência econômica, onde a cultura é simplesmente transplantada. A partir de 1870, com a evolução dos processos produtivos e de comercialização, os ideais de república causaram modificações nas classes da sociedade brasileira, dando origem à classe média - que, mais tarde, passou a ter um papel significativo na demanda por educação. Iniciou-se o processo de urbanização. A República chegou marcada pelo ideário positivista (originário da Revolução Industrial). Os republicanos propuseram a liberdade e a "popularidade" da educação, investindo em ensino público e gratuito. Depois da 1a Guerra Mundial, a sociedade fortaleceu a valorização da educação enquanto processo de formação cultural e profissional (ideologia liberal7). Os liberais assumiram uma postura progressista, transformadora, entrando em conflito com a ideologia católica, conservadora; passando a educação a enfrentar forte resistência da Igreja Católica. Porém, quanto ao efetivo acesso à educação, mesmo estando a ideologia educacional brasileira marcada ou pela ideologia liberal ou pela católica, não alcançou as camadas populares do País (maioria da população), dando continuidade à seletividade (SEVERINO, 1986; AZANHA, 1992 e MELLO, 1983²).

A partir de 1920 a urbanização se intensificou com o crescimento da nova classe dominante: a burguesia urbano-industrial. A evolução do capitalismo brasileiro formou, noutro pólo, as classes subalternas (o proletariado urbano). De 1930 a 1964, o Estado se preocupava, de acordo com sua política educacional, em preservar os interesses da classe dominante, fazendo devidas concessões aos interesses das classes média e popular urbanas, quando não era mais possível ignorar (SEVERINO, 1986¹0).

No período getulista, acabou-se consolidando o dualismo da educação brasileira: para as elites, escolas que classificavam socialmente; para as classes menos favorecidas (maioria), as escolas que preparavam mais rapidamente para o trabalho. Em 1961, após 13 anos de tramitação no Congresso Nacional, a $1^{a}$ Lei Brasileira de Diretrizes e Bases da

\footnotetext{
7 "Sistema de idéias elaborado por ingleses e franceses, no contexto das lutas de classe, da burguesia contra a aristocracia, ...que serviram de bandeira à Revolução Francesa" (CUNHA, 1975, apud V. MALLIO \& PALMA FILHO, p. 5, 1992); Econ. Doutrina que enfatiza a iniciativa individual, a concorrência entre agentes econômicos e a ausência de interferência governamental, como princípios de organização econômica (DICIONÁRIO AURÉLIO, 1993)

8 apud PALMA FILHO (1992)

${ }^{9}$ apud V. MALLIO (1992)

10 Apud PALMA FILHO (1992)
} 
Educação Nacional é promulgada (no governo de Juscelino Kubitscheck, em seu Plano de Metas), não conseguindo dotar o País do sistema educacional que necessitava (SEVERINO, 198611). Após essa iniciativa pioneira, sucederam-se, em 30 anos, cerca de dez planos que, revistos e abandonados, refletiram os males gerais da administração pública brasileira, como também o fato de que a educação brasileira nunca fora prioridade (AZANHA, 1992).

A partir de 1964 - ao contrário do que propunha a ideologia liberal nacionalista de 1930 - o Brasil abre as portas ao mercado internacional, instaurando-se "O Milagre Econômico Brasileiro". Este modelo transferiu para as camadas de renda mais baixa o ônus do combate à inflação, implicando diretamente na queda da qualidade de vida. (BASTOS, 1995). Como conseqüência, o sistema educacional teve que se adequar ao modelo de desenvolvimento econômico. Em 1968, a Lei 5540 reformulou o ensino superior e, em 1971, com a Lei 5962, reestruturou-se o sistema primário e médio. Esse sistema passou a apoiar 0 grupo privado, passando a educação a ser encarada como um empreendimento econômico (no tópico que se segue, essas últimas mudanças apresentadas serão novamente mostradas, porém, sob outra ótica).

A década de 80, com governantes eleitos pelo voto direto, foi marcada pelos debates em torno da escola pública e a canalização de esforços para recuperá-la. Criaram-se os Conselhos de Escola, que quase se transformaram em sinônimo de autonomia pleiteada, ficando o Município dotado de capacidade normativa. Segundo ROMÃO (1994), isso resultou na esperança de os projetos continuarem a ser desenvolvidos no mandato seguinte do governo que sai. Para AZANHA (1987) ${ }^{12}$, a autonomia da escola é "algo que se põe com relação à liberdade de formular e executar um projeto educativo".

Segundo SOUZA E SILVA (1992), o alastramento na sociedade da consciência de que a educação é fundamental se deve à atuação da imprensa, das universidades, das organizações não-governamentais. NEUBAUER DA SILVA \& MELLO (1991) afirmam ser a educação uma preocupação não apenas dos países em desenvolvimento. Atribui, ainda, tal

${ }^{11}$ Apud PALMA FILHO (1992)

12 Apud WARDE, M. J. (1992), p. 85. 
preocupação a dois fatores: o primeiro deles se refere a uma mudança profunda nas demandas, devido ao avanço tecnológico dos anos 80, ao impacto da informatização, à globalização econômica e aos novos modelos de organização. O segundo fator se refere ao esgotamento do modelo econômico sustentado por mão-de-obra barata e obra-prima abundante, necessitando, então, de um novo direcionamento de prioridades para investimentos. Os mesmos autores também afirmam que a capacidade de produzir, selecionar e interpretar informação passam a ser altamente valorizadas.

\subsubsection{Das Leis}

Pela CONSTITUIÇÃO FEDERAL de 1988, no Art. 30, "compete aos municípios:

$$
\begin{aligned}
& \text { VI - manter, com a cooperação técnica e financeira da } \\
& \text { União e do Estado, programas de educação pré-escolar } \\
& \text { e de ensino fundamental." }
\end{aligned}
$$

Até hoje, existe uma controvérsia muito grande por parte dos educadores e responsáveis pelo setor escolar quanto a essa resolução (APEOESP, 1996). O Estado de São Paulo é o maior exemplo disso, onde, ainda hoje, $80 \%$ do ensino fundamental está sob a responsabilidade do Estado, restando ao Município os 20\% restantes, somados os $100 \%$ do ensino infantil (pré-escola). Devido a esta problemática, algumas medidas estão sendo implementadas, tratadas no próximo item (Municipalização Escolar).

Em 1993, do ESTATUTO DA CRIANÇA E DO ADOLESCENTE (1993) - em seu artigo $3^{\circ}$, tem-se que:

"A criança e o adolescente gozam de todos os direitos fundamentais inerentes à pessoa humana, sem prejuízo da proteção integral de que trata esta Lei, assegurando-seIhes, por lei ou por outros meios, todas as oportunidades e facilidades, a fim de lhes facultar o desenvolvimento físico, mental, moral, espiritual e social, em condições de dignidade e liberdade." 
No artigo 53, desta mesma Lei Federal, tem-se que:

"A criança e o adolescente têm o direito à educação, visando ao pleno desenvolvimento de sua pessoa, preparo para o exercício da cidadania e qualificação para o trabalho, assegurando-se-Ihes: .....acesso à escola pública e gratuita próxima de sua residência.

\subsubsection{Municipalização da Rede de Ensino}

A Emenda Constitucional no 14, aprovada em 1996 pelo Congresso Nacional, transforma a questão da municipalização do ensino em um dos principais temas de debate das entidades da sociedade civil. Esta emenda institui o Fundo de Manutenção e Desenvolvimento do Ensino Fundamental e de Valorização do Magistério (vulgo "Fundão"). Segundo a APEOSP (1996), esta emenda "confisca" parte das receitas de estados e municípios (15\% do ICMS e dos repasses que o Estado recebe da União e 15\% dos repasses que o Município recebe), fazendo o repasse dos recursos de acordo com o número de alunos de cada esfera de governo. Em outras palavras, para o Município receber de volta esses recursos, terá que criar redes municipais ou assumir escolas da rede estadual. 0 problema consiste no fato de que o Município não estará recebendo mais por isso, apenas terá que estar repassando os parcos recursos que recebe em outras áreas de ensino. $A$ APEOESP (1996) critica o governo no tocante à priorização que está dando ao ensino fundamental, onde acaba por negligenciar a educação infantil ( 0 a 6 anos), haja vista querer sobrecarregar o Município.

Por São Paulo apresentar sua divisão de jurisdição diferente da maioria dos estados brasileiros (lembrando que, com a Constituição de 1988, as responsabilidades do Município foram ampliadas), o Fundão não traria benefícios aos municípios deste estado, haja vista a rede estadual de São Paulo ter ainda $80 \%$ do ensino fundamental sob sua responsabilidade (o inverso dos demais estados). Assim, com as discussões geradas pelas categorias de ensino, o governo decidiu adiar o Fundão para o ano de 1998, deixando a adesão voluntária por parte dos municípios já a partir do início de 1997. (APEOESP, 1996). 
Com a Municipalização, muita coisa vai mudar, principalmente para os docentes, especialistas e funcionários, como os direitos à gratificação, remoção, dispensa, dentre outros, gerando descontentamento na categoria. (APEOSP, 1996).

- Objetivos do Fundão

Segundo o SINDICATO DE ESPECIALISTAS DE EDUCAÇÃO DO MAGISTÉRIO OFICIAL DO ESTADO DE SÃO PAULO (1996a), baseada na disparidade entre a realidade educacional dos diversos estados, a Emenda Constitucional tem, então, dois objetivos principais:

- Função redistributiva - estados, como São Paulo, assumem mais de $80 \%$ da rede escolar, enquanto outros, o inverso, determinado pela Constituição de 1988.

- Função contábil - hoje, os estados e municípios são obrigados a aplicar nada menos que $25 \%$ da receita, resultante de impostos, na manutenção e desenvolvimento do ensino (pela Constituição Federal). Porém, em cada Estado, esse valor mínimo limitante pode variar, não existindo um critério para a definição do percentual mínimo necessário (nunca sendo menor, é claro, que os 25\%). A Constituição Gaúcha, por exemplo, aplica 35\% no mínimo, enquanto que, São Paulo, 30\%. Com a criação do Fundo, o controle contábil será facilitado, pelos Tribunais de Contas ou pelo próprio Estado, dificultando gastos não julgados estritamente necessários.

Alcançando-se os objetivos a que se propõe a Emenda, haverá melhor redistribuição salarial, diminuindo o desvio-padrão dos salários dos professores (já tão sofridos), estabelecendo-se um salário-mínimo de $\mathrm{R} \$ 300,00$ (trezentos reais) como retribuição ao trabalho de um professor por uma jornada de vinte horas semanais - mesmo em São Paulo, existem professores que ganham essa mesma quantia, já com as gratificações e, o que é 
pior, em outros estados, esse salário cai para $\mathrm{R} \$ 60,00$ (sessenta reais) (SINDICATO DE ESPECIALISTAS DE EDUCAÇÃO DO MAGISTÉRIO OFICIAL DO ESTADO DE SÃO PAULO, 1996a).

Uma das formas de verificar o grau de satisfação dos objetivos previstos em lei foi a criação do censo escolar obrigatório das escolas, realizado anualmente, onde são analisados níveis de aprovação/reprovação, evasão, aprendizagem, etc. (SINDICATO DE ESPECIALISTAS DE EDUCAÇÃO DO MAGISTÉRIO OFICIAL DO ESTADO DE SÃO PAULO, 1996b)

\subsubsection{Investimentos na Educação}

Reconhecendo que o Brasil investe pouco em educação (em torno de 3,5\% do PIB, quando a UNESCO, em 1992, recomendou 11\%), as entidades de educação propuseram um Fundo que significasse aumento substancial de investimentos. Segundo essas entidades, a Emenda proposta pelo atual governo (Fundão) não elevará o montante dos recursos vinculados à educação, e sim, apenas redistribuirá o que já estava destinado. Um outro agravante, também debatido, refere-se a um maior descomprometimento da União com 0 financiamento do ensino fundamental (APEOSP, 1996).

DIMENSTEIN (1995) faz uma crítica ao comparar os salários de professores norteamericanos com os de brasileiros, onde estes chegam a ser até cem vezes menores que os primeiros. O mesmo autor também compara os gastos com a demanda escolar: nos EUA, cada aluno em escola pública representa um gasto anual ao governo de US\$ 6.000,00 (seis mil dólares). Em países como o Japão, Cingapura e Israel esses números ainda são maiores. No Brasil, a meta é de se chegar a um gasto de $\mathrm{R} \$ 300,00$ (quase trezentos dólares) por criança anualmente, e poucos são os que se indignam com esses números. "Nossas elites exibem a satisfação do medíocre orgulhoso com sua mediocridade".

MELLO (1985) atribui ao MEC (Ministério da Educação e Cultura) o papel de coordenador e articulador da política educacional que subsidiará a questão, 
(Estado/Município), nos mais variados aspectos - currículos, conteúdos programáticos, política de formação de professores, garantia de qualidades das construções escolares, materiais didáticos e pedagógicos, apoio técnico e agilização de recursos às regiões mais carentes.

\subsubsection{Fatores que Influem na Escolaridade da População}

A inexistência de escolas em número suficiente, a entrada tardia na escola, as taxas elevadas de reprovação e a intensa evasão determinam o baixo nível de escolaridade do país (CUNHA, 197513). Anteriormente, visto como um fenômeno que dizia respeito às qualidades e dedicação do aluno - de forma individual, o fracasso escolar, a partir do anos 60, passou a ser encarado como uma falha do sistema como um todo. A baixa qualidade de vida, a impossibilidade de uma ascensão a um padrão mais digno, a marginalização dos processos sociais, culturais e produtivos da sociedade e a condenação de legar aos filhos 0 mesmo precário padrão de vida que levam os pais tornam o fracasso escolar um problema social cada vez maior. Assim, a Escola tem que entender seu papel social e sua função numa sociedade de grupos bastante diversificados, objetivando a uma compensação, na qual, padrões, exigidos pela própria Escola, possam ser alcançados e o fracasso escolar caia significativamente (POPPOVIC, 1983). MELLO (1986)14 conclui, afirmando que não poderá existir uma escola igualitária numa sociedade desigual.

\subsubsection{Democratização e Qualidade no Ensino}

Democratização do ensino implica em acesso do aluno à Escola, permanência e término e qualidade do ensino. O acesso é uma questão de política educacional e a dificuldade a este é um fator que age contra a democratização do ensino. A qualidade do ensino é um fator de democratização na medida que eleva o patamar de compreensão dos alunos em suas relações com a realidade, não sendo, no entanto, observado nas escolas (LUCKESI, 1992).

${ }^{13}$ apud MALLIO \& PALMA FILHO (1992) 
Apesar de todas as dificuldades, existem municípios que estão dando exemplos de compromisso para com a comunidade, gerando ensino de qualidade, de forma a alcançar a demanda como um todo. São casos como os de Icapuí (CE), Cascavel (PR) e Nova Friburgo (RJ), que, mesmo enfrentando dificuldades, desenvolveram boas experiências e mostram que, com vontade política, o Brasil pode resolver a grave crise do ensino básico. Muitas vezes, soluções simples, mas bem planejadas, que levam em conta as necessidades específicas da comunidade e, adequadamente implantadas, dão bons resultados. Para isso, a comunidade tem que se voltar e dar prioridade para a educação. Foi o caso de Icapuí que, para atender a total demanda, improvisaram salas de aula em locais disponíveis, como igrejas, salões e residências desocupadas. Hoje, a principal meta da Secretaria de Educação de Icapuí passou a ser a melhoria da qualidade de ensino. No caso de Cascavel, esta "driblou" a legislação, criando uma fundação de caráter privado, a qual recebeu da Prefeitura a incumbência de administrar uma parcela da rede municipal de ensino. Sendo legalmente uma empresa privada, ela tem acesso direto ao salário-educação, pago pelas empresas do município. Em Nova Friburgo, a questão da qualidade de vida é a base para a educação do povo, cujo segredo reside na continuidade administrativa e na vontade política de investir na qualidade do ensino.

\subsection{Reorganização Escolar}

Entenda-se como Reorganização Escolar o remanejamento de alunos e professores da rede estadual de São Paulo dos ensinos fundamental e médio, cujo passo inicial foi a separação física dessas duas classes estudantis. Segundo a SECRETARIA DE ESTADO DA EDUCAÇÃO DE SÃO PAULO (1995), o projeto de separação do modelo pedagógico é um fim em si mesmo, não se vinculando, necessariamente, à municipalização.

14 apud CENTRO DO PROFESSORADO PAULISTA (1992) 


\subsubsection{Breve Histórico}

A unificação, em 1968, dos cursos Primário e Ginasial, eliminou a barreira dos exames de admissão que separava esses cursos. Foi regulamentada, apenas, em 1971, com a Lei no 5692, que criou, efetivamente, a escola de primeiro grau. Esta lei instituiu, de modo pioneiro, a escolaridade mínima de 8 anos para toda a população escolar da faixa de 7 a 14 anos (SECRETARIA DE ESTADO DA EDUCAÇÃO DE SÃO PAULO, 1996a).

Com essa modificação, as escolas juntaram alunos de diferentes níveis e faixas etárias. $\mathrm{Na}$ época, os principais motivos alegados para a junção foram os de que a mesma faria com que 0 abismo entre as $4^{\mathrm{a}}$ e $5^{\mathrm{a}}$ séries diminuísse, estimulando a integração pedagógica, e, que a medida ajudaria a racionalizar recursos. Passaram-se 25 anos e o que se previu não aconteceu. Em se tratando de dinheiro dos contribuintes e - mais importante da educação de cerca de sete milhões de alunos, as instituições responsáveis pelo ensino têm a obrigação de mudar o que não está sendo bem sucedido (SECRETARIA DE ESTADO DA EDUCAÇÃO DE SÃO PAULO, 1995).

Em 1983, em consulta à Rede Estadual, os educadores sugeriram a reorganização como uma das formas de melhorar a qualidade de ensino. A partir daí, o projeto passou a constar do programa de governo da época. Somente em 04/12/1995, com a Resolução SE265, é que foi efetivado (DIÁRIO OFICIAL DO ESTADO, 1995). Esta Resolução dispõe sobre as diretrizes para a Reorganização das Escolas da Rede Estadual e dá providências correlatas (SECRETARIA DE ESTADO DA EDUCAÇÃO DE SÃO PAULO, 1995).

\subsubsection{Objetivos da Reorganização Escolar}

Resumidamente, os principais objetivos da reorganização são (SECRETARIA DE ESTADO DA EDUCAÇÃO DE SÃO PAULO 1995, 1996a, 1996b, e 1996c):

- chegar-se ao atendimento exemplar - com a reorganização, as escolas poderão planejar um atendimento eficaz aos estudantes de diferentes 
faixas etárias. Com o apoio do cadastro, poderá se saber quantos são e onde estão os alunos;

- racionalizar o uso dos prédios escolares e, com isso, aumentar a oferta de vagas para $02^{\circ}$ grau, principalmente no período diurno, onde, anteriormente, os jovens estudavam no período noturno por falta de opção;

- acabar com a repetência e a evasão escolares;

- aumentar a carga horária no ensino fundamental, passando os alunos de $1^{\mathrm{a}}$ a $4^{\mathrm{a}}$ séries a ter uma hora a mais de aula diariamente ${ }^{15}$;

- efetivação do ensino obrigatório de 8 anos;

- dar melhores condições aos professores para que estes também melhorem a qualidade do ensino;

- aumentar a jornada dos professores para 40 horas, passando estes a ter uma única classe, e não mais duas, obtendo mais tempo para 0 planejamento escolar, e

- otimizar o trabalho dos diretores das escolas - a limitação da faixa etária pode tornar isso possível.

\subsubsection{Procedimentos Adotados pela Reorganização}

A reorganização ponderou alguns aspectos (alguns deles especificados na Resolução SE-265, de 1995). Dentre os mais relevantes, tem-se:

- a indicação dos prédios térreos para as classes de $1^{\mathrm{a}}$ à $4^{\mathrm{a}}$ séries e, os maiores, com quadras e laboratórios, indicados para as classes de $5^{a}$ série em diante;

Alegações: com a definição/limitação da demanda, as escolas poderão ter um melhor funcionamento - os estudantes terão ambientes pedagógicos adequados

\footnotetext{
${ }^{15}$ Com a ampliação da jornada escolar, de quatro para cinco horas diárias, mais de 2.5 milhões terão, ao final de quatro
} anos, um ano a mais de escolarização (SECRETARIA DE GOVERNO E GESTÃO ESTRATÉGICA, 1996). 
às suas necessidades e, os professores, mais tempo para reunirem-se e aperfeiçoarem-se. As escolas de $1^{\text {a }}$ a $4^{\text {a }}$ séries devem ter perfil, planejamento e preocupações diferentes das que atendem adolescentes e jovens adultos, onde a separação física fornece condições de uma melhor integração (SECRETARIA DE ESTADO DA EDUCAÇÃO DE SÃO PAULO, 1995).

- a indicação da realocação dos alunos envolvidos para a escola mais próxima da, então, reorganizada;

- a distribuição adequada das escolas nas regiões e as conveniências dos alunos;

- o cadastro dos alunos para dar um panorama preciso da demanda;

- a utilização de outros subsídios, tais como mapas atualizados dos municípios, com indicação de barreiras físicas e a precisa localização das escolas, para que se tivessem maiores recursos no auxílio à tomada de decisões;

- o número máximo de alunos previsto por turma nas classes de $1^{\text {a a }} 4^{a}$ séries (30 a 35 alunos), e

- número mínimo de 12 classes em funcionamento diurno e 10, no noturno. (SECRETARIA DE ESTADO DA EDUCAÇÃO DE SÃO PAULO, 1996b).

A operacionalização do remanejamento se daria com o consenso dos delegados de ensino, dos supervisores e diretores das escolas, onde, com 0 apoio de várias entidades envolvidas, estes responsáveis atuariam sobre um diagnóstico preciso da realidade, tomando por base 0 conhecimento da estrutura e organização das escolas. As mudanças só deveriam ocorrer após todas essa ponderações (SECRETARIA DE ESTADO DA EDUCAÇÃO DE SÃO PAULO, 1995). 


\subsubsection{Alguns Resultados da Reorganização}

Segundo a SECRETARIA DE ESTADO DA EDUCAÇÃO DE SÃO PAULO (1997), alguns resultados importantes já puderam ser observados:

- aumento do número de escolas funcionando nos dois turnos, que passou de 999 para 2397 (SECRETARIA DE ESTADO DA EDUCAÇÃO DE SÃO PAULO (1996c);

- efetivação do aumento na carga horária do ensino fundamental em uma hora;

- diminuição da evasão (de 1995 para 1996, passou de 9.1 para 7.6\%);

- diminuição do número de reprovações (de 11.7\%, em 1995, para 8.6\%, em 1996, com conseqüente diminuição de gastos - estimados em 600 milhões anuais - advindos da repetência);

- maior patamar de aprovação dos últimos vinte anos: 83\% (em 1994 este índice era de 77\%).

Ressalta-se aqui que, antes mesmo da implantação dessa reformulação no ensino do Estado de São Paulo, onde o primeiro passo foi fazer a separação física de alunos, já se falava do aumento de deslocamento das classes estudantis envolvidas. No entanto, mesmo com esse aumento (desconhecido, até agora), o fato de haver melhorias no desempenho da demanda no ensino e da própria instituição de ensino compensaria a distância a mais a ser percorrida (SECRETARIA DE ESTADO DA EDUCAÇÃO DE SÃO PAULO, 1995).

Segundo COSTA (1996c) ${ }^{16}$, um dos objetivos da reorganização é diminuir a distância entre o Estatuto da Criança e do Adolescente (ECA) e a realidade. Segundo ele, "existe uma controvérsia sobre a atitude de alguns em relação à Lei 8.069-ECA. Uns querem piorar a Lei, para que ela fique parecida com a realidade, e outros querem melhorar a realidade, para que ela se aproxime cada vez mais da Lei."

\footnotetext{
${ }^{16}$ apud SECRETARIA DE ESTADO DA EDUCAÇÃO DE SÃO PAULO (1996c)
} 
A Reorganização também surtiu seus efeitos negativos, sobretudo com o corpo docente. O Sindicato dos Professores de São Paulo critica as demissões advindas da Reorganização, a "pulverização do sindicato" nos municípios e, ainda, a queda no nível médio de sindicalização - de 17 para 16.2\%, segundo o IBGE, entre 1993 e 1995 (APEOESP, 1996).

\subsection{Transporte Escolar}

Dar escolas não é o bastante. É preciso também dar condições ao aluno de chegar até a unidade de ensino. Pensando assim, Icapuí (CE) - premiada pela Unicef pelo exemplo de sua dedicação ao ensino - complementou o planejamento da rede física com um sistema de transporte escolar gratuito, o qual permite que estudantes se desloquem de unidades menos graduadas para outras que Ihes dêem ensino mais qualificado. Isso permitiu que todos os alunos de $1^{\circ}$ e $2^{\circ}$ graus tenham acesso às escolas no próprio município e, aqueles que quiserem ingressar na universidade também têm o transporte pago para os centros mais próximos. Esses gastos com transportes consomem 25\% do orçamento destinado à educação.

Para garantir o transporte de alunos eventualmente transferidos para escolas mais distantes, as Delegacias de Ensino do Estado de São Paulo já receberam mais de R\$ 2,6 milhões para compra de passes e aluguel de ônibus escolares e, para regiões mais pobres, os governos Federal e Estadual enviaram recursos da ordem de 5 milhões para a compra de veículos escolares (SECRETARIA DE GOVERNO E GESTÃO ESTRATÉGICA, 1996).

Segundo THORNTHWAITE \& PETTITT (1995), os Estados Unidos se destacam na maneira de atender ao setor estudantil, no tocante ao transporte escolar (yellow buses), chegando a gastar 9,8 bilhões de dólares por ano. Muitos de seus estados se utilizam de tecnologias desenvolvidas especificamente para este setor, com 0 intuito de diminuir despesas com veículos e combustível. 
Na bibliografia pesquisada foi encontrada uma restrição de caminhada dada às crianças do Reino Unido e Estados Unidos, países que se preocupam com o problema, devido ao fato de pagarem o transporte escolar motorizado, caso as distâncias máximas previstas em lei sejam excedidas. Segundo THORNTHWAIT \& PETTITT (1995), as distâncias máximas admitidas nos Estados Unidos são aproximadamente iguais à metade das admitidas no Reino Unido. Estas distâncias variam dentro do próprio Reino Unido, geralmente sendo admitidos os percursos de até 2 milhas $(3,2 \mathrm{~km})$ para crianças até oito anos e 3 milhas $(4,8 \mathrm{~km})$ para crianças com idade superior (THORNTHWAIT, 1994).

No Brasil, mais especificamente em São Paulo, o Município paga transporte escolar para crianças da área rural, bem como para aquelas que, com a Reorganização Escolar, passaram a ter um trajeto maior até a escola. Até recentemente, a grande maioria dos veículos utilizados era de propriedade das prefeituras municipais, mas atualmente, as prefeituras têm contratado empresas ou indivíduos, terceirizando o serviço. No caso do transporte escolar rural, os itinerários dos veículos são fixados anualmente em função da localização da residência das crianças, geralmente, buscando-se evitar que elas percorram caminhadas superiores a 2 ou 3km até o ponto onde o veículo passa (GEIPOT, 1995). A TABELA 2.1 mostra o impacto do transporte na escolarização das crianças rurais.

TABELA 2.1 - Impacto do Transporte na Escolarização das Crianças Rurais (Estado de São Paulo)

\begin{tabular}{|c|c|c|c|c|c|c|}
\hline \multirow[t]{2}{*}{ Séries } & \multicolumn{2}{|c|}{$\begin{array}{c}\text { Estudantes } \\
\text { transportados para } \\
\text { escolas rurais }\end{array}$} & \multicolumn{2}{|c|}{$\begin{array}{c}\text { Estudantes } \\
\text { transportados para } \\
\text { escolas urbanas }\end{array}$} & \multicolumn{2}{|c|}{ Total } \\
\hline & "Número & \%\% & Número & \%\% & Núnero & \%\% \\
\hline $1^{a}-4^{a}$ & 225.517 & 92,8 & 81.272 & 56,7 & 306.789 & 79,4 \\
\hline $5^{a}-8^{a}$ & 17.493 & 7,2 & 62.064 & 43,3 & 79.557 & 20,6 \\
\hline Total & 243.010 & 100,0 & 143.336 & 100,0 & 386.346 & 100,0 \\
\hline
\end{tabular}




\subsubsection{Das Leis}

Pelo Art. 208, da Constituição Federal, "O dever do Estado com a educação será efetivado mediante a garantia de:

VIII - atendimento ao educando, no ensino fundamental, através de programas suplementares de material didático-escolar, transporte, alimentação e assistência à saúde.

\$ $2^{0}-\mathrm{O}$ não oferecimento do ensino obrigatório pelo Poder Público, ou sua oferta irregular, importa responsabilidade da autoridade competente.

Art. 206 - 0 ensino será ministrado com base nos seguintes princípios:

I - Igualdade de condições para o acesso e permanência na escola.

VASCONCELLOS (1997) afirma que, nos EUA, a operação e manutenção do transporte escolar se dividem entre o setor público (70\%) e as empresas privadas (30\%). No caso brasileiro, estes dados são mostrados na TABELA 2.2, em um estudo desenvolvido em Campinas (SP).

O mesmo autor conclui que só a garantia do transporte pode fazer valer a garantia constitucional do direito à educação, defendendo o transporte gratuito sempre que a escola não estiver ao alcance da viagem a pé e que o planejamento do transporte escolar é indissociável do planejamento da distribuição física da rede. 
TABELA 2.2 - Estudantes Transportados Segundo o Meio de Transporte (Campinas-SP)

\begin{tabular}{lcc}
\hline \hline \multicolumn{1}{c}{ Tipo de Serviço } & \multicolumn{2}{c}{ Estudantes } \\
& Número & $\%$ \\
\hline \hline Privado(1) & 10.273 & 31,0 \\
Público(2) & 16.768 & 48,5 \\
Linhas Regulares & 7.082 & 20,5 \\
Total & 34.573 & 100,0 \\
\hline \hline
\end{tabular}

(1) Veículos e motoristas contratados no mercado local

(2) Veículos de propriedade pública, dirigidos por funcionários públicos.

Fonte: VASCONCELLOS (1995)

\subsubsection{Dos Custos}

Os custos envolvidos no transporte escolar são geralmente medidos pela quilometragem média percorrida. No caso de previsões de custos, algumas variáveis são importantíssimas para a correta previsão destes, sejam (GEIPOT, 1995):

i) a localização da escola, centralizada ou não, em relação à área geográfica, à malha rodoviária ou ao centro geográfico da população;

ii) densidade demográfica das zonas de atendimento;

iii) distância máxima que o aluno deve andar (geralmente 2 ou $3 \mathrm{~km}$ );

iv) tipos de veículos, lotações desejadas e extensão das linhas e

v) número de turnos de operação dos veículos.

Também numa estimativa de custos, dada pelo GEIPOT (1995), em um estudo feito sobre uma suposta implementação de um programa de custeio, chegou-se à conclusão de que no oitavo e último ano de implantação, o custo anual por criança transportada seria de US\$13,60 (pequeno em relação aos benefícios esperados). Nos Estados Unidos, o mais 
baixo custo obtido foi a de US\$ 0,54 e 0,60/km (em 1992), que, se comparado ao estipulado anteriormente para o Brasil (US\$ 0,52/km), traria um resultado favorável à nossa demanda ${ }^{17}$. Em São Paulo (maior estado investidor nessa área), gasta-se um valor aproximado de US\$ 1,00 por dia (VASCONCELLOS, 1997).

"O transporte escolar deve ser parte integrante do direito à educação e não um acessório eventual, o qual tem implicações diretas no planejamento e financiamento dos sistemas de transportes". (VASCONCELLOS, 1997, p. 47)

17 Isso se deveria mais ao fato de serem baixos os salários pagos aos motoristas no Brasil - em média, dez vezes menores que os pagos nos EUA. 
CAPÍTULO 3

\title{
3. SISTEMAS DE INFORMAÇÕES GEOGRÁFICAS (SIGs)
}

\begin{abstract}
Este capítulo apresenta os SIGs, dando-se, inicialmente, uma introdução, onde algumas definições, funções, e conceitos básicos são apresentados. Posteriormente, o capítulo aborda algumas estratégias de implementação e aplicações de SIGs, chegando-se à questão do planejamento urbano, onde também são apresentados alguns trabalhos desenvolvidos que se utilizaram desse mesmo ferramental. Termina-se o capítulo com uma breve descrição dos SIGs-T (Sistemas de Informações Geográficas Aplicados aos Transportes).
\end{abstract}

\subsection{Introdução aos SIGs:}

\subsubsection{Definições:}

"São sistemas automatizados, usados para armazenar, analisar e manipular dados geográficos, ou seja, dados que representam objetos e fenômenos em que a localização geográfica é uma característica inerente à informação e indispensável para analisá-la" (S. ARONOFF, 1989 \& G. BULL, 1994) 1 .

"Conjunto de procedimentos que permitem analisar, processar, inter-relacionar e mapear qualquer conjunto de características que cumpram com a condição de ser referenciáveis e georeferenciáveis (referenciadas à terra) e que sejam elementos geográficos - comumente representados por pontos, linhas e áreas." (BRAVO F. \& CERDA T., 1995, p. 548).

\footnotetext{
1 apud CÂMARA et al., 1997, p. 21
} 


\subsubsection{Histórico}

No final do século XIX, a Geografia correu sério risco de desaparecer devido ao fato de ter-se desfragmentado em várias disciplinas (Astronomia, Geologia, Climatologia, Hidrologia, Orografia, etc.). Em 1882, o alemão Friederich Ratzel solucionou a questão pela inclusão do homem e suas atividades. A partir daí, a Geografia se converteu em uma só ciência, que abordava e analisava a relação do homem e o meio, passando, então, a uma ciência humana (BUZAI \& DURÁN, 1997).

A "geografia humanista", por outro lado, valorizou concomitantemente a questão subjetiva, a percepção e os mapas mentais (BUTTIMER, 1974 e 1977, \& TUAN, 1974)². A FIGURA 3.1 ilustra a evolução temporal do pensamento geográfico segundo Buttimer e Tuan.

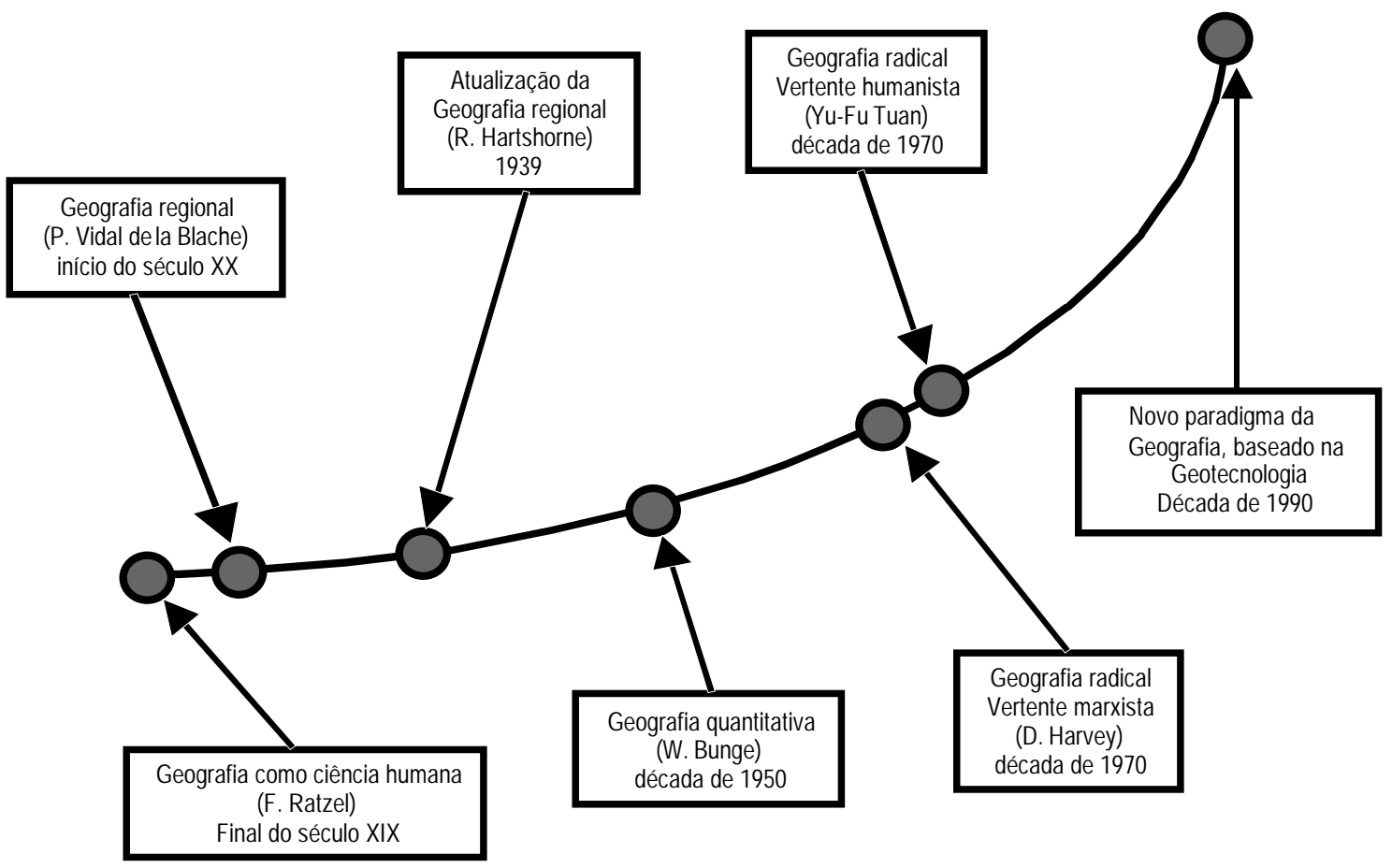

FIGURA 3.1 - Evolução do Pensamento Geográfico como Ciência Humana

Fonte: BUZAI \& DURÁN, 1997 
A adoção da abordagem sistêmica na ciência geográfica, seguida do uso de técnicas de quantificação, baseadas em procedimentos estatísticos e na linguagem matemática, bem como o desenvolvimento tecnológico, revolucionaram a segunda metade deste século. $A$ primeira, devido ao fato de ter proporcionado uma maior compatibilização de análise e interpretação da organização espacial. O desenvolvimento tecnológico, por sua vez, propiciou a medida direta ou a elaboração de documentos, tais como as imagens orbitais, aumentando significativamente 0 ritmo de obtenção de dados a respeito de fenômenos terrestres. Com isso, novos procedimentos técnicos se tornaram necessários para 0 manuseio dessas informações. Os Sistemas de Informações Geográficas se inserem nesse contexto técnico-científico como instrumental valioso à pesquisa e ao público interessado nessas questões. Estes sistemas são constituídos por uma série de programas e processos de análise, cuja característica principal é focalizar o relacionamento de determinado fenômeno da realidade à sua localização espacial (TEIXEIRA et al., 1992). Segundo estes mesmos autores, a localização específica do fenômeno é apenas uma parte do processo, haja vista ser possível o estudo de outros aspectos mais complexos, como os de vizinhança e contigüidade, envolvendo áreas mais extensas.

Antes do advento dos SIGs, a análise e manutenção de entidades em um contexto espaço-temporal era executada de forma analógica, onde 0 processamento e a apresentação dos dados eram feitos através de mapas e cartas (forma mais antiga e ainda mais comum). A produção de mapas é um processo caro, cujos elementos, em geral, são armazenados de forma georeferenciada, segundo um sistema de coordenadas (latitude, longitude, elevação em relação ao nível do mar). Com a sobreposição de mapas em folhas transparentes é possível se fazer a correlação desses dados; no entanto, é um processo oneroso. Com os SIGs, foi possível diminuir gastos com essa produção, armazenamento e atualização manuais de mapas. Segundo ANTENUCCI et al. (1991)32, as primeiras tentativas de automatizar o processo de georeferenciamento de dados ocorreram na década de 50, na Grã-Bretanha (para uma pesquisa em botânica) e nos Estados Unidos (em Chicago, para uma pesquisa de análise de tráfego).

\footnotetext{
2 apud BUZAI \& DURÁN (1997)

3 apud CÂMARA et al. (1997)
} 
O primeiro sistema a ter as características básicas de um SIG foi o Canadian Geographic Information Systems (1964), desenvolvido no Canadá. Em 1967, apareceram os sistemas New York Landuse and Natural Resources Information Systems e, em 1969, 0 Minnesota Land Management Information System. Devido aos custos elevados e a problemas de implementação, a aplicação desses sistemas se restringiu às agências federais e estaduais dos Estados Unidos e Canadá. Com os avanços obtidos em equipamentos e software no decorrer dos anos seguintes, tornou-se possível uma considerável redução nos custos, com conseqüente difusão e aceitação dos SIGs em todo o mundo (TEIXEIRA, 1992).

\subsubsection{Espaço Geográfico e Ambiente Computacional}

Dois fatores significativos influem na descrição dos SIGs: sua aplicação em diversas áreas (Geografia, Planejamento Urbano, Engenharia, Processamento de Dados, Arquitetura e Urbanismo, Ciências Ambientais, entre outras) e a consistência do conjunto de ferramentas que os profissionais destas áreas usam para implementar seus trabalhos, aumentando a eficiência e a eficácia na geração de informações gráficas e descritivas (HUXHOLD, 1991). "Em função desta amplitude de perfis de usuários, tipos de dados e necessidades das aplicações, os SIGs também precisam prover aos usuários e projetistas de aplicações um conjunto adequado de funções de análise e manipulações dos dados geográficos." (CÂMARA et al., p. 27, 1997). Nesse aspecto de multidisciplinaridade dos SIGs, BORROUGH (1986) $)^{4}$ faz a seguinte asserção:

\footnotetext{
"Basicamente, todas as disciplinas atentam para o mesmo tipo de operação - desenvolver um poderoso conjunto de ferramentas para coletar, ordenar, corrigir com prontidão, transformar e retratar dados espaciais de um mundo real para um conjunto de propósitos."
}

Segundo BUZAI \& DURÁN (1997), o homem tem uma visão parcial da realidade. Por outro lado, os instrumentos de medição que utiliza para capturar tal percepção permitem possíveis aproximações da realidade. Com todas essas limitações, criam-se modelos do

\footnotetext{
4 apud HUXHOLD (1991)
} 
mundo real, onde os elementos e suas reais relações passam a ser elementos e relações representados (transformação do mundo real para um modelo conceitual). Nesse processo de representação, o homem se torna o ponto central de enfoque, tendo em vista ser este 0 que faz a captura do espaço geográfico (objeto de estudo), mediante a observação e medição, e que, através de um processo seletivo, obtém uma representação do modelo conceitual (FIGURA 3.2). CÂMARA et al. (1997) se refere à modelagem de dados como sendo o processo de abstração dos fenômenos do mundo real para a criação da organização lógica do banco de dados.
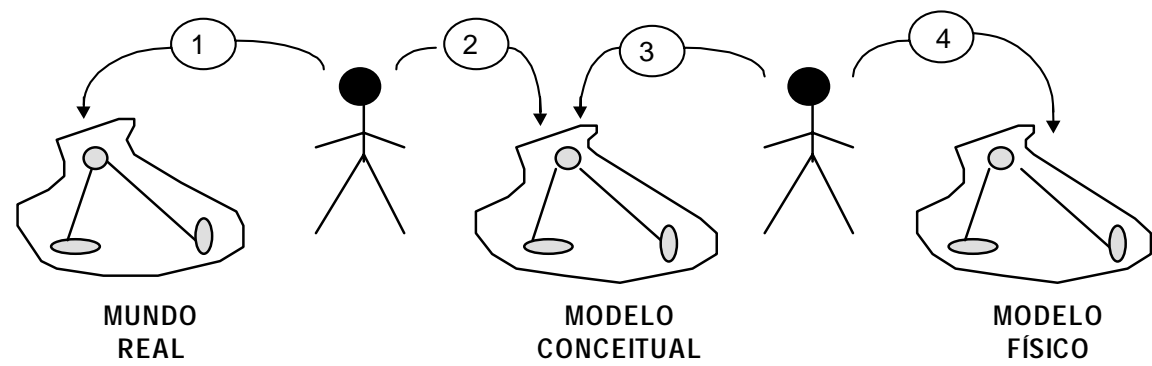

1. Observações e medições

2. Representação conceitual da realidade

3. Análise do modelo conceitual

4. Representação digital do modelo conceitual

FIGURA 3.2- Transformações Conceituais

Fonte: BUZAI \& DURÁN (1997)

Ainda segundo BUZAI \& DURÁN (1997), as entidades e relações representadas passam para 0 ambiente computacional mediante procedimentos técnicos, através da codificação da informação alfanumérica e a geocodificação das entidades gráficas. Com isso, efetiva-se a passagem do modelo conceitual para o modelo digital (FIGURA 3.3). Um mundo real transformado em um mundo digital apresenta possibilidades de manejo da informação gráfica. As técnicas de geoprocessamento são cada vez mais freqüentes para modelar nosso entorno, mediante a utilização de computadores. 


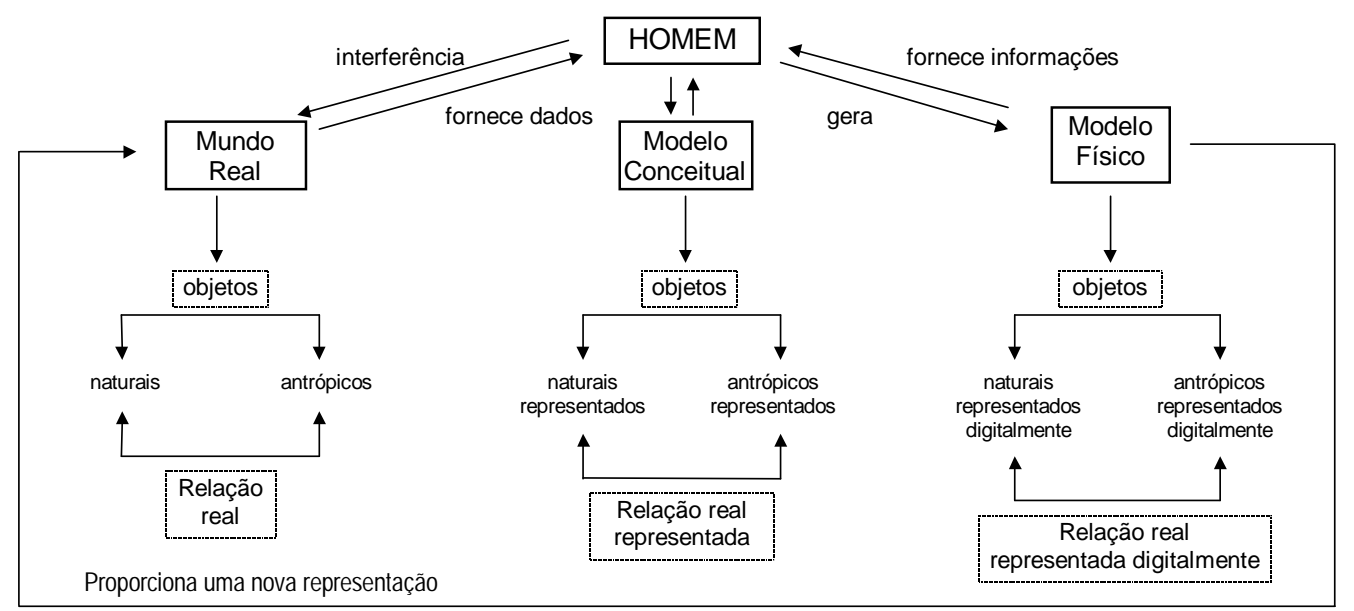

FIGURA 3.3 - Transformações Conceituais: do Mundo Real ao Mundo Digital

Fonte: BUZAI \& DURÁN (1997)

\subsubsection{Algumas Funções e Vantagens dos SIGs}

Segundo CÂMARA (1994), as funções de um SIG são:

- integrar informações espaciais de dados cartográficos, censitários e de cadastro, imagens de satélite, redes e modelos numéricos de terreno, numa única base de dados;

- cruzar informações através de algoritmos de manipulação para gerar mapeamentos derivados, e

- consultar, recuperar, visualizar e permitir saídas gráficas para o conteúdo da base de dados geocodificados.

Os SIGs abrangem diferentes tipos de dados e aplicações nas mais variadas áreas do conhecimento. Como exemplo, tem-se a otimização do tráfego; controle cadastral; gerenciamento de serviços e de utilidade pública; demografia; cartografia; administração de recursos naturais; monitoramento costeiro, controle de epidemias; planejamento urbano. Sua utilização facilita a integração de dados coletados de fontes diferentes (CÂMARA et al., 1997). 
Em um contexto que abranja modelos de transportes, KAGAN et al. (1992) apresentam as principais vantagens do uso dos SIGs, sejam:

- a integridade dos dados, onde também estando o SIG integrado aos modelos, permite a maior transparência dos aspectos físicos dos dados para o usuário;

- operações pré-incorporadas aos SIGs eliminam ou simplificam tarefas, as quais são, normalmente, realizadas por processos manuais ou em módulos computacionais isolados e não muito bem integrados;

- facilidade de edição e representação gráfica;

- tratamento topológico que facilita operações de edição da base geográfica;

- minimização de custos com armazenamento e edição de informações e

- facilidade na análise de tarefas difíceis de serem realizadas manualmente, como é o caso da verificação do caminho mínimo.

No planejamento de transportes, os SIGs aumentam a acurácia e eficiência de levantamentos de dados referentes à matriz O-D (origem/destino), bem como provêem detalhados resultados de análises espaciais da evolução dos mesmos serviços (HSIAO \& STERLING; 1993).

\subsubsection{Conceitos Básicos}

Para melhor se entender um SIG, é necessário que se conheça a definição de alguns conceitos básicos, sejam (TEIXEIRA et al., 1992):

- sistema: conjunto de entidades (elementos ou coisas) relacionadas ou conectadas, de forma a constituírem uma unidade ou um todo organizado, possuindo características próprias, subordinadas a processos de transformação conhecidos; 
- entidades: são os elementos ou objetos tomados como unidades básicas para a coleta dos dados. Os dados, por sua vez, relacionam-se com os atributos, que caracterizam e fornecem significado à unidade estudada (como exemplo, pode-se tomar um lugar geográfico qualquer como entidade, e suas características de solo, vegetação, etc. como alguns de seus atributos);

- dados: conjunto de valores, numéricos ou não, sem significado próprio;

- informação: é o significado que o ser humano atribui aos dados, ou ainda, é 0 conjunto de dados que possuem significado para determinado uso ou aplicação Como informação geográfica, considera-se o conjunto de dados cujo significado contém associações ou relações de natureza espacial. Esses dados podem ser apresentados em forma gráfica (pontos, linhas e polígonos), numérica ou alfanumérica.

Desta forma, um SIG se utiliza de uma base de dados computadorizada, que contém informação espacial (os aspectos do meio natural), sobre a qual atuam uma série de operadores espaciais (conjunto de operações algébricas, booleanas e geométricas). Um SIG pode ser visto como um sistema composto por um banco de dados, por um conjunto de software, dedicado à execução de operações sobre os dados (análise espacial), e pelo hardware, conclui TEIXEIRA (1992). RODRIGUES (1993) complementa, somando-se a estes componentes citados, os procedimentos organizacionais que alimentam o sistema com dados e, dele, alimentam-se com informações - enfatizando a importância dos aspectos organizacionais, quando da implantação de SIGs em prefeituras, empresas de infra-estrutura urbana, etc.

\subsubsection{Fontes de Dados e Estruturas de Representação}

Os dados utilizados em um SIG podem ser oriundos de várias fontes, classificadas, de um modo geral, em primárias e secundárias. As fontes primárias envolvem os levantamentos feitos diretamente no campo ou sobre produtos do sensoriamento remoto, enquanto que as secundárias envolvem mapas e estatísticas, advindos das fontes primárias. A definição do uso das fontes em um projeto irá depender de fatores como níveis de 
detalhamento, precisão, custos, possibilidade de padronização e abrangência espacial (TEIXEIRA et al., 1992). CÂMARA et al. (1997) dão uma visão mais abrangente da arquitetura dos SIGs (FIGURA 3.4).

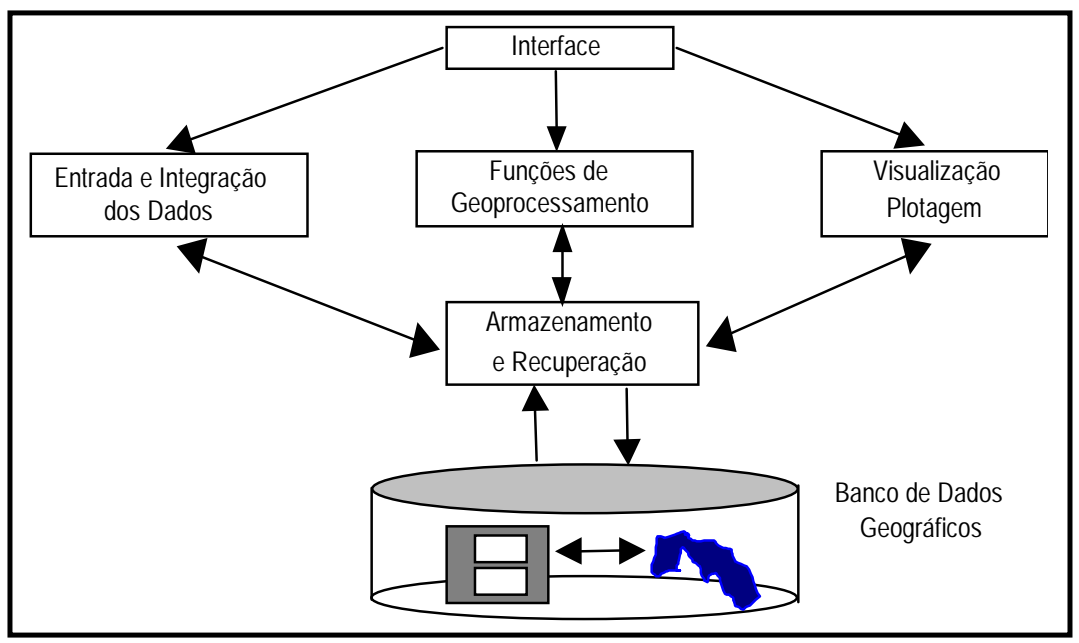

FIGURA 3.4 - Arquitetura de Sistemas de Informações Geográficas

Fonte: CÂMARA et al., 1997

Ainda em relação à FIGURA 3.4, a interface com o usuário se dá através da linguagem de comandos. A integração de dados pode-se dar de quatro principais formas: entrada de dados via caderneta de campo, via digitalização em mesa, através da digitalização ótica (com dispositivos de varredura - scanners) e pela leitura de dados na forma digital, incluindo, ainda, a importação de dados em outros formatos. No Brasil, as principais fontes de dados são oriundas do IBGE, do INPE e do Centro de Cartografia Automatizada do Exército (CCAE). Com o GPS (Sistema de Posicionamento Global), tornouse possível a realização de trabalhos de campo com alto grau de precisão e com registro digital direto. A digitalização ainda é o modo mais usado, feita a partir de mapas ${ }^{5}$ existentes. A digitalização ótica se dá através de dispositivos de varreduras (scanners e CCD - change coupled devices). As funções de geoprocessamento dependem dos tipos de dados (superposição, ponderação, medidas, retificação, contraste, filtragem, caminhos ótimos e

5 A Carografia classifica a representação de entidades gráficas em três grupos principais: plantas (escalas até 1/10.000), cartas (escalas de 1/10.000 até 1/50.000) e mapas (escalas acima de 1/50.000). Em algumas ocasiões, neste trabalho, a palavra mapa estará representando, na verdade, a palavra planta. 
críticos, etc.). O ambiente de visualização é conseqüência da interface. Alguns sistemas dispõem de recursos altamente sofisticados (plotagem, legendas, textos explicativos, etc.). Os dados de um SIG são geralmente armazenados sob a forma de um banco de dados geográficos.

Segundo TEIXEIRA et al. (1992), as estruturas organizacionais do espaço se dividem em duas classes: as estruturas não-geométricas e as geométricas. As primeiras se utilizam de dados que incluem atributos (nomes, população, atividade econômica, etc.), ao passo que, as segundas descrevem diversos atributos de um elemento (topologia). As estruturas geométricas se subdividem em raster e vetorial (FIGURA 3.5), cuja diferença básica reside no modelo de espaço adotado em cada uma (divisão do espaço em elementos discretos e espaço geográfico contínuo, respectivamente).

Os sistemas raster trabalham em forma matricial, onde cada célula ou pixel (picture element) da matriz contém uma unidade da informação. Neste formato, a nitidez e a precisão de uma imagem irá depender do tamanho do pixel (denominada resolução). Os sistemas vetoriais definem, para cada ponto espacial, um vetor de $n$ dimensões, onde as duas primeiras coordenadas se referem ao sistema cartesiano utilizado. As componentes restantes do vetor se referem aos demais atributos. Neste caso, as situações espaciais são determinadas por funções matemáticas (BRAVO F. \& CERDA T., 1995). A TABELA 3.1 compara as principais vantagens e desvantagens de ambos os formatos. 


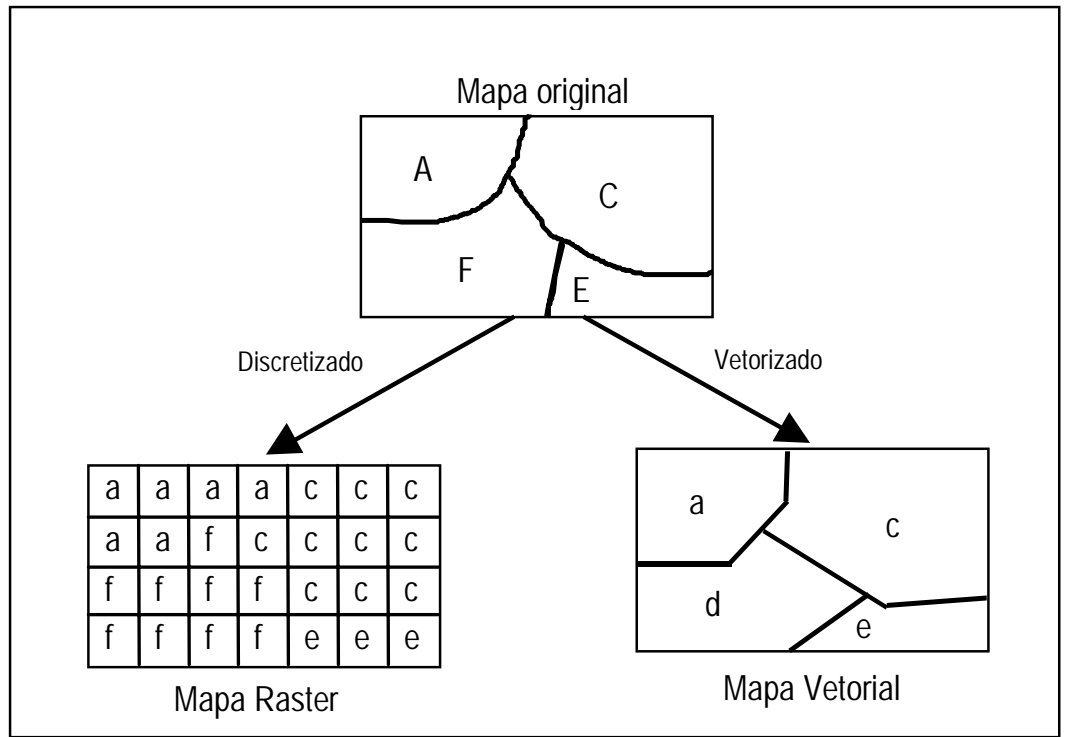

FIGURA 3.5: Formas de Representação dos Dados

Fonte: TEIXEIRA et al., 1992

TABELA 3.1 - Vantagens e Desvantagens dos Formatos Raster e Vetorial

\begin{tabular}{|c|c|c|}
\hline Formato & Vantagens & Desvantagens \\
\hline RASTER & $\begin{array}{l}\text { - } \text { estrutura de dados simples } \\
\text { - eficiência em análises de superposição de } \\
\text { áreas } \\
\text { - boa representação da variabilidade } \\
\text { espacial } \\
\text { - eficiência na manipulação de imagens } \\
\text { digitais }\end{array}$ & $\begin{array}{l}\text { - estrutura pouco compacta } \\
\text { - difícil representação das relações } \\
\text { - topológicas } \\
\text { - saídas gráficas com má delineação }\end{array}$ \\
\hline VETORIAL & $\begin{array}{l}\text { - } \text { estrutura de dados compacta } \\
\text { - eficiência na representação e análise das } \\
\text { relações topológicas } \\
\text { - } \quad \text { saídas gráficas com boa definição de traços }\end{array}$ & $\begin{array}{ll}\text { - } & \text { estrutura de dados complexa } \\
\text { - } & \text { difícil análise na superposição de áreas } \\
\text { - } & \text { representação regular da variabilidade } \\
& \text { espacial } \\
\text { - } & \text { difícil análise de imagens digitais }\end{array}$ \\
\hline
\end{tabular}

Fonte: BRAVO F. \& CERDA T. (1995) 


\subsubsection{Diferenças entre Algumas Terminologias Empregadas}

- Geoprocessamento e SIGs

Entenda-se por Geoprocessamento como um conjunto de tecnologias de coleta, tratamento, manipulação e apresentação de informações espaciais. Existem vários tipos de sistemas de Geoprocessamento, tais como sistemas de digitalização, sistemas de conversão de dados, sistemas de modelagem digital de terreno, sistemas de processamento de imagens, entre outros, e os Sistemas de Informações Geográficas. Todos estes tratam de informações espaciais, possuindo cada um função particular e peculiaridades. A peculiaridade dos SIGs reside no fato de os mesmos serem sistemas voltados primordialmente à gestão da informação e não à realização de tarefas, como os demais sistemas em Geoprocessamento (RODRIGUES, 1993).

Segundo VALDEPEÑA (1994), Geoprocessamento envolve um conceito mais global, relacionado-se, às atividades de sensoriamento remoto, cadastros e outros tipos de pesquisas e investigações de campo para obtenção de dados. Ou seja, o Geoprocessamento pode ser necessário à montagem do banco de dados; no entanto, para a manipulação, organização e atualização das informações, usam-se os SIGs - parte final do Geoprocessamento.

- SIG e CAD

A grande maioria dos SIGs são resultados da evolução de sistemas de processamento de imagens ou de aperfeiçoamentos em sistemas CAD (Computer Aided Design). Esta evolução natural se deveu ao fato de algumas pessoas trabalharem com imagens de satélite ou análises sobre estas, e, outras, com a digitalização de mapas, redes etc. Na grande maioria dos casos, as funções geográficas foram incluídas nas ferramentas já existentes. Boa parte dessa evolução está longe de representar dados geográficos, embora resultados concretos possam ser retirados em níveis de representação gráfica (PIMENTEL et al., 1994). 
CÂMARA afirma ser 0 tratamento das relações espaciais entre objetos uma característica básica num SIG. Define, ainda, a topologia como sendo a estrutura de relacionamentos espaciais (vizinhança, proximidade, pertinência) que se pode estabelecer entre objetos geográficos. "Armazenar a topologia de um mapa é o que difere um SIG de um CAD", completa (ver também SILVA et al., 1997).

Segundo HUXHOLD (1991), quando o homem observa um mapa, pode distinguir quais as entidades (pontos, linhas, áreas) adjacentes, tem a noção de sentido (o que está à direita ou à esquerda desta entidade), quais os pontos ligados em uma dada interseção, etc. O computador, no entanto, precisa ser informado a respeito desse relacionamento espacial entre essas entidades. Assim, topologia é definida como sendo a maneira de representação de características de pontos, linhas e áreas em um mapa e, segundo PAREDES (1994), seus principais conceitos podem ser dados em termos de:

- conectividade - permite que arcos sejam ligados entre si por meio de nós;

- circunscrividade - permite que arcos ligados possam definir polígonos;

- contigüidade - permite que arcos possuam direção e lados, e

- orientação - permite identificar quais nós estão ligados entre si.

\subsection{Estratégias de Implantação e Aplicações de um SIG}

Segundo CÂMARA et al. (1997), o processo de implantação de um SIG se divide em três grandes fases: modelagem do mundo real, criação do banco de dados e operação. A fase de modelagem do mundo real (FIGURA 3.2) consiste na seleção de fenômenos e entidades de interesse, dando-se a abstração e generalização. A fase que envolve a criação do banco de dados representa uma grande parcela do custo total, podendo ser minimizada através da escolha de uma modelagem adequada. Ainda nessa segunda fase, várias etapas são exigidas: coleta dos dados, correção dos dados e o georeferenciamento dos dados. A última fase (operação) se refere ao desenvolvimento de aplicações específicas a partir dos dados armazenados, reconstruindo visões da realidade. 
MAGUIRE, D. et al. (1993)6 classificam as aplicações de SIGs em sócioeconômicas (envolvendo o uso da terra, seres humanos, e a infra-estrutura existente), ambientais (meio ambiente e o uso dos recursos naturais) e de gerenciamento (realização de estudos e projeções para uma melhor alocação de recursos).

Mesmo com a grande aplicação dos SIGs em diversas áreas e ciências, na grande maioria dos casos, os programas se encontram subutilizados por efeito do desconhecimento destes, pela falta de hardware necessário, pela falta de objetivos claros quando de sua aplicação, pela falta de desenvolvimento teórico dos processos, etc. Devido a isto é que a escolha e posterior implementação de um SIG em qualquer campo de aplicação requer um estudo prévio, capaz de identificar qual o melhor sistema a ser empregado. (BRAVO F. \& CERDA T., 1995).

A função de suporte dada pelo SIG empregado irá depender de sua correta escolha. A escolha deve se dar de forma a se ter um melhor modelo que se adeqüe à situação, como observado por ROSSETO \& CUNHA (1994). Concluem, ainda, que o grande desafio que se enfrenta está na definição de modelos que possibilitem considerar as restrições encontradas nos problemas reais. 0 modelo deve se adaptar ao problema a ser resolvido e, não 0 contrário, onde a simplificação do problema se dá de forma a adaptá-lo ao modelo existente.

Não se deve esquecer que um SIG não sobrevive sem resultados positivos. Para tanto, o projeto precisa ter metas quanto aos usos e benefícios. Um modo de garantir tais benefícios e usos de um SIG em um projeto é desenvolver o SIG em função do uso. Primeiramente, devem-se definir os usos e, a partir daí, o SIG, minimizando riscos de inviabilização (FERRARI, 1997).

\subsection{SIGs e Planejamento Urbano}

O crescimento e a concentração espacial da população geram maior demanda e, conseqüentemente, maior défice nos serviços que lhe são prestados. 0 processo de

\footnotetext{
6 apud CÂMARA et al. (1997)
} 
urbanização do Brasil é um dos mais rápidos do mundo, aumentando a diversidade das interrelações existentes entre as diversas partes que compõem a área urbana (a população urbana aumentou 8,61 vezes de 1940 para 1991; em 1941, a taxa de urbanização era de 31,24\%, enquanto que em 1991 passou a 75,86\%). Com isto, a complexidade na administração do espaço urbano foi ampliada. A informatização dos dados é justificada pela necessidade de realização de serviços de forma integrada, manipulando-se dados complexos, agilizando-se o processo quando da realização de tarefas de difícil execução manual (AMORIM \& SILVA, 1994). Com isso, torna-se clara a justificativa de se ter um SIG como ferramenta de apoio no planejamento.

FERRARI (1997) classifica as diversas atividades de uma organização em três níveis e enquadra o uso dos SIGs em cada uma delas. Sejam: o nível operacional, nível gerencial e nível estratégico, cada um contendo características próprias. O nível operacional trata das atividades corriqueiras da organização, geralmente, volumosas e trabalhosas (ex.: compensação de cheques e linha de montagem). O uso dos SIGs neste nível faz com que se tenha um aumento na eficiência operacional, isto é, aumento de produtividade, com conseguinte economia de recursos. O nível gerencial trata das decisões de caráter tático (ex.: qual a melhor localização para um determinado serviço?). Aqui, como benefício imediato do uso dos SIGs, tem-se a eficácia administrativa, ou seja, boas informações, bons planos, bom gerenciamento, boas decisões. Por último, o nível estratégico lida com as atividades que contribuem diretamente para o cumprimento dos objetivos fundamentais da organização (ex.: aumento da satisfação da demanda e aumento da margem de lucro). 0 autor, quando da aplicação dos SIGs neste nível, faz alusões à imagem da administração pública, melhorando-a perante outras entidades (parceiros) e clientes (demanda), facilitando a aprovação de projetos, aquisição de financiamentos etc.

ALMEIDA \& GONÇALVES (1996) afirmam ser as decisões estratégicas aquelas que envolvem grandes quantidades de recursos e, geralmente, com efeitos de longo e médio prazos. Definem, ainda, planejamento como sendo "um processo de previsão de necessidades e racionalização do uso de meios materiais e recursos humanos disponíveis, a fim de alcançar determinados objetivos em prazos e etapas pré-definidos, possuindo, ainda, 
dimensões políticas e administrativas". Assim, o planejamento de serviços de infra-estrutura básica em setores da sociedade precisa assegurar à mesma a existência de um número adequado de unidades de serviço.

\subsubsection{Cadastro e SIGs}

Segundo HERNÁNDEZ (1990), para o planejamento dos serviços públicos ofertados em uma determinada área urbana, planos cadastrais servem como recursos de localização para estes. O uso do cadastro vem desde a antiga Grécia e, depois, no Império Romano, quando houve a necessidade de serem estabelecidos impostos sobre a propriedade, relacionando-a com seu proprietário. Posteriormente, o cadastro se apresentou como um inventário da propriedade urbana e rural, formado essencialmente de porções de mapas com a função de definir a situação espacial da propriedade, seus limites e características, incluindo uma parte escrita com dados técnicos, econômicos e jurídicos. Tendo o cadastro urbano fundamentalmente, que:
i) localizar os bens urbanos;
ii) definir características;
iii) identificar proprietários ou pessoas relacionadas com estes e
iv) determinar a valorização econômica.

Com o dinamismo de instituições e de setores econômicos, a necessidade de obtenção de informações com respeito ao território e aos aspectos relacionados a este marcam a atual sociedade. O tratamento e a qualidade dessas informações se fazem imprescindíveis, principalmente no âmbito municipal, onde a quantidade de informações cresce a cada dia. Um sistema de informações se aponta como elo das diversas fontes de dados, podendo ser definido como um conjunto de dados, medidas e atividades (bem como sua interação) que permitem o tratamento da informação (PEREÑA, 1990).

Considerando a dinâmica urbana brasileira, vê-se que nem sempre é possível acompanhar tecnologicamente as transformações decorridas apenas com recursos de 
cadastro, como já acontece em países do primeiro mundo. Na bibliografia consultada, há quem atribua o fato à cultura do povo - cujas raízes estão na história, na vida social, na política e no direito - não acompanhando a velocidade da tecnologia, imprimindo resistência à esta. O uso do geoprocessamento, que permite posicionar no espaço (através de um sistema de coordenadas) os atributos de uma determinada entidade, vem se tornando uma poderosa ferramenta para o planejamento urbano através da disseminação dos Sistemas de Informações Geográficas.

\subsubsection{SIGs na Localização de Instalações}

Em termos gerais, dois padrões de localização de instalações de serviços e equipamentos urbanos devem ser considerados: o de estar o mais próximo possível da demanda (com 0 intuito de reduzir custos em transportes) e 0 de reduzir ao máximo os custos com instalações, seja pela escolha de uma localização devido ao custo financeiro, ou pela quantidade de instalações a serem estabelecidas (LEONARDI, 1981). Segundo esse autor, as duas considerações são conflitantes, visto que para uma determinada instalação estar mais próxima da demanda a servir implica dizer que um maior número de unidades terá que ser ofertado, onerando gastos com instalação. Com isso, a análise de localização e distribuição dessas instalações não pode se dar de modo separado.

Assim, com relação à escolha de um projeto, em detrimento de um outro de mesma finalidade, a preferência será dada ao que conseguir atender a uma maior demanda, com um número mínimo de unidades projetadas - dito economicamente mais viável. Desta forma, as estratégias de localização são de suma importância, visto que a economia obtida ao deixar de construir uma unidade reduzirá as chances de oferta deste serviço, denotando, desta forma, a difícil conciliação entre o fator economia e a satisfação das necessidades demandadas. Ressalta-se, aqui, que custos em transportes envolvem não somente custo monetário, bem como aspectos relacionados ao tempo de percurso, distância percorrida, oportunidade de escolha, dentre outros, que têm diferentes influências para distintas classes de demanda. 
Ainda segundo LEONARDI (1981), para se definir a localização, devem-se efetuar algumas análises como a de comparação da dimensão e localização atual com a demanda alocada; avaliação dos custos e benefícios associados ao estado atual do sistema, bem como àqueles associados a possíveis mudanças e, a geração de novos padrões de capacidade e localização de instalações (construindo novas ou alterando seu uso). Quanto à decisão de distribuição das instalações, deve-se fazer a comparação entre a máxima demanda gerada (demanda potencial) de cada ponto geográfico com a capacidade e a localização da instalação existente e os custos em transportes entre a demanda e a localização (não necessariamente medidos em termos de dinheiro); e, ainda, a geração de padrões de viagens da demanda para com a instalação, levando-se em consideração os custos em transportes e a capacidade disponível.

Dada a restrição de recursos para a construção e manutenção de novas unidades de serviço à comunidade, uma melhor organização espacial das já existentes seria uma estratégia lógica a ser seguida. OPPONG \& HODGSON (1994) propõem essa estratégica lógica em um estudo sobre a realocação de serviços em postos de saúde em um país de terceiro mundo (Gana). Neste estudo, levou-se em consideração o modo a pé, tido por mais popular, visto se tratar de um país pobre. Os autores usaram modelos de localização e distribuição como meios de medir a acessibilidade espacial. Em termos de localizar e distribuir atividades, os autores definem a acessibilidade geográfica de duas formas: proximidade e alcance. Quando pela proximidade, a acessibilidade tem a conotação de minimizar distância, podendo ser medida em termos da distância média (p-medianas). Pesquisas anteriores encontraram a distância como o maior determinante de uso das instalações (STOCK, 19927). A acessibilidade também pode ser dada usando-se uma distância máxima de alcance (a pessoa atendida pelo serviço é dita coberta). Se a instalação estiver dentro dos limites de distâncias pré-estabelecidos, é considerada acessível. Caso contrário, não. O algoritmo empregado se utilizou da distância Euclidiana (distância em linha reta entre dois pontos).

\footnotetext{
7 apud OPPONG \& HODGSON (1994)
} 
Um outro problema de localização também foi citado por NOVAES \& ROSSETO (1993), quando se depararam com a definição de localização de depósitos de bebidas no estado de Santa Catarina. Este trabalho também se utilizou da métrica euclidiana, porém corrigida por um fator $k$, visto a mesma ser irreal (toma a distância em linha reta). Isso se deveu ao fato de não se ter a malha viária digitalizada disponível. Os autores também associaram o problema clássico de localização a Stern que, em 1837, analisou a questão da localização do ponto central, onde, dados três pontos quaisquer, o objetivo seria a determinação da coordenada deste ponto central, tal que a soma das distâncias até os outros três pontos fosse mínima. Estendeu-se o estudo para $n$ pontos. Sob a ótica logística, este problema corresponde à localização de instalações de modo a maximizar a acessibilidade.

Os Sistemas de Informações Geográficas vêm sendo utilizados nos Estados Unidos para assegurar o uso do transporte escolar de maneira a minimizar os gastos. Segundo THORNTHWAITE \& PETTITT (1995), este país se destaca na maneira de atender ao setor estudantil, no tocante ao transporte escolar (yellow buses), chegando a gastar 9,8 bilhões de dólares por ano. Muitos de seus estados se utilizam de softwares desenvolvidos especificamente para este setor (o Edulog e o Ecotrans são os mais difundidos no mercado norte-americano).

Um estudo pioneiro no Brasil no que tange ao problema de alocação de matrículas em escolas públicas, citado por FONSECA \& ZUPPO (1996), foi o caso de Belo Horizonte. A administração da cidade implementou um cadastro de endereços, como base de um projeto de geoprocessamento urbano e uma das linhas de ação se dirigiu a informações georeferenciadas de escolas e alunos. O caso, aqui analisado, inspirou-se nesse estudo e seu produto visa um comparativo de algumas medidas, tomadas por órgãos de ensino da cidade de São Carlos, comparando-as com outras medidas semelhantes, porém feitas com uma ferramenta capaz de ofertar divisões zonais e alocações mais coerentes dos alunos que as, então, adotadas. O aspecto mais importante dessa aplicação é que ela foi totalmente desenvolvida em um equipamento de custo relativamente baixo, acessível, até mesmo, a prefeituras de cidades pequenas e médias. 


\subsection{Sistemas de Informações Geográficas Aplicados aos Transportes (SIGs-T)}

Em termos simplificados, SIGs-T são a adaptação e adoção dos SIGs para questões relacionadas aos transportes. Mais especificamente, é um ambiente de captura, gerenciamento e análise de dados espaciais relativos aos transportes (LANGFORD \& LEWIS, 1995). Segundo os mesmos autores, essa tecnologia foi aplicada mais efetivamente a partir de 1992/1993, onde, com a sua utilização, ficou mais fácil analisar a segmentação dinâmica (ou seja, ligar atributos lineares ou de pontos a uma rede) e a própria análise em rede (menor caminho, tráfego, viagens de vendas, alocação em rede e outros focos dados por algoritmos analíticos).

Para efeito de classificação e caracterização da informação utilizada na Engenharia de Transportes, BRAVO F. \& CERDA T. (1995) fazem a divisão dessa informação em três grandes grupos:

- Informação de natureza cadastral - proveniente, geralmente, de grandes entidades, como ministérios e órgãos públicos (no Brasil, 0 IBGE);

- Informação de terreno - fundamentalmente, apresentada sob a forma de pontos geográficos (nós) e ligações entre estes (arcos), de maneira a formar uma malha conexa (rede viária de transporte); em termos de demanda, a informação é dada por um conjunto regiões/áreas, denominadas zonas, nas quais a interação espacial entre as mesmas pode-se dar através de matrizes origem-destino, e

- Informação resultante de Modelagens e Simulações - proveniente dos modelos de transporte (viagens produzidas e atraídas, custos de viagens entre zonas, tipos de veículos e movimentos em interseções, níveis de serviço, informações de passageiros de transporte público, etc.). 
Resumidamente, os elementos geográficos que são utilizados nos SIGs são pontos, linhas e áreas; as informações manejadas nos sistemas de transportes se referem a três elementos espaciais: nós, arcos e zonas. Por apresentarem formatos e padrões similares, os quais permitem sua integração operativa, há a possibilidade de implementação das tecnologias SIG à análise dos sistemas de transportes. BRAVO F. \& CERDA T. (1995) concluem que, ao se considerar os elementos de análise de ambos, pode-se estabelecer uma compatibilidade total entre estes sistemas. 


\section{CAPÍTULO 4}

\section{METODOLOGIA}

Neste capítulo, expõe-se o método a ser aplicado no estudo de caso. A primeira parte do capítulo traz as abordagens dadas ao trabalho. Na segunda parte, comenta-se sobre a aquisição dos dados, justificando o uso de algumas medidas de ajuste aplicadas. Em seguida, faz-se a breve descrição das rotinas do software empregadas e seus respectivos resultados gerados. Conclui-se o capítulo com a exposição sumária do método, enumerando-se todos procedimentos.

\subsection{Abordagens do Trabalho}

Este trabalho contém duas abordagem de pesquisa. Estas abordagens se deram em duas etapas distintas, apresentadas a seguir. Esta divisão se deveu, inicialmente, ao fato de não se poder garantir a obtenção de alguns dados da população a se estudar.

\section{- PRIMEIRA ETAPA}

Esta etapa contou com as informações das escolas públicas e com os setores censitários do IBGE, ambos georeferenciados. A análise da demanda foi feita através de demarcações de zonas, que levou em consideração a divisão setorial já feita pelo IBGE$^{1}$ (a título de ilustração, a FIGURA 4.1 mostra a demarcação de setores censitários e seus respectivos centróides na cidade de São Carlos). Adotou-se o centróide de cada uma destas zonas como o suposto ponto de origem das viagens analisadas, haja vista não se conhecer 0 real posicionamento de cada aluno. A partir daí, foram iniciadas as simulações, objetivando encontrar uma melhor distribuição espacial destas escolas, resultando em soluções 
minimizadoras de custos de deslocamento para demanda. Finalizou-se, assim, esta etapa com a análise dos resultados obtidos das simulações, utilizando-se de algumas rotinas do software, adiante mencionadas. Esta etapa permitiu a comparação dos percursos médios anterior e posterior à reorganização escolar da demanda, a partir da utilização de variáveis do censo do IBGE de 1991, apontando possíveis realocações de serviços.

FIGURA 4.1 - Divisão Setorial do IBGE com Respectivos Centróides

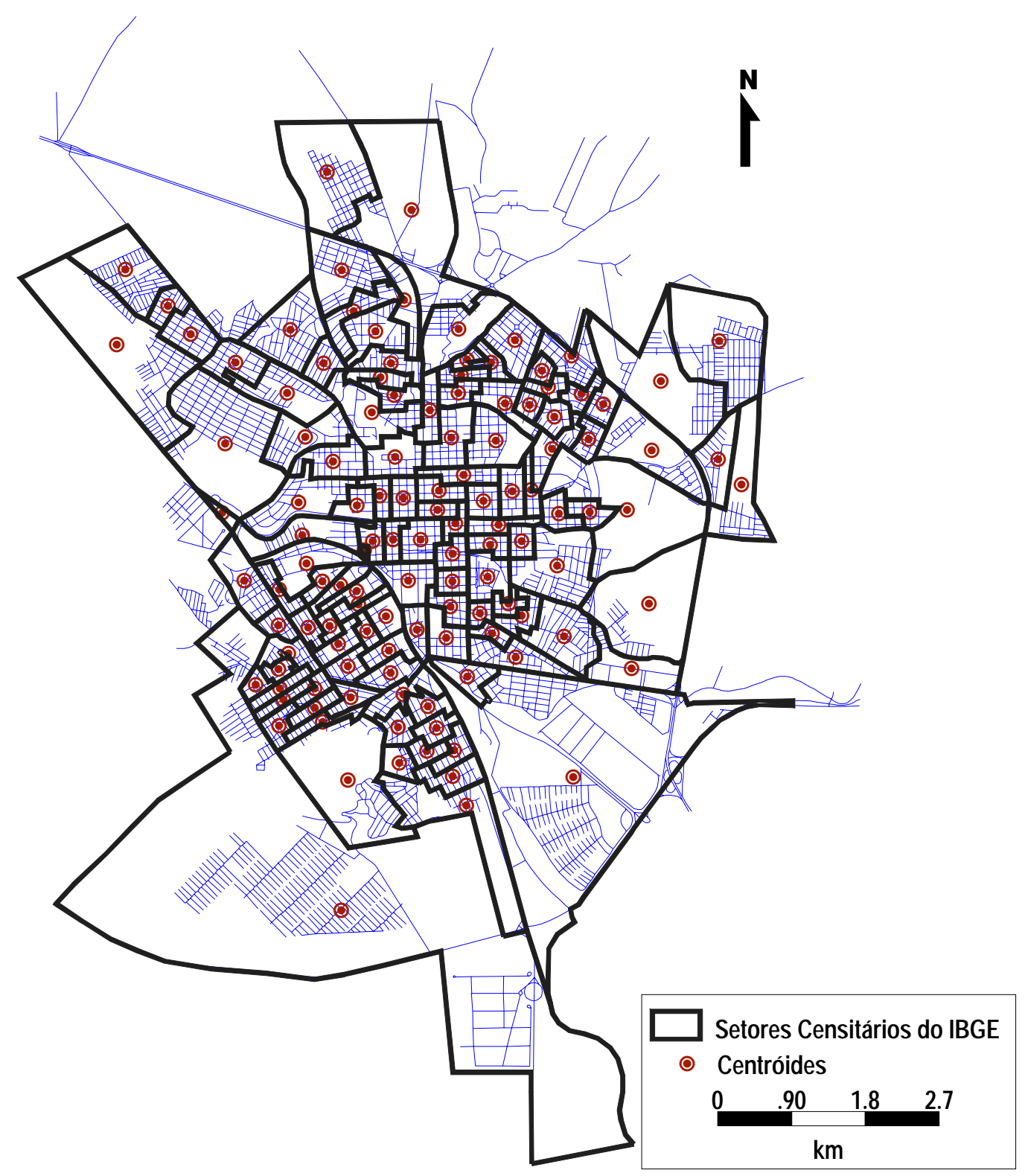

1 O método de divisão setorial adotado pelo IBGE parte de um valor médio de domicílios, adotado por setor, podendo este variar de 250 a 350 unidades (informação verbal obtida no escritório do IBGE de São Carlos, 1997). 


\section{- SEGUNDA ETAPA}

Esta fase deveria contar com todos os procedimentos da etapa anterior, acrescidos do cadastro dos endereços dos alunos, identificando o verdadeiro ponto de origem de cada um. Para tanto, seria necessária a conclusão de uma base de dados, em formato digital, que contivesse todas as informações das residências (logradouro, número e CEP-Código de Endereçamento Postal). Com isto, ter-se-ia uma melhor representação da realidade, pois com os dados fornecidos pelo IBGE, utilizados na primeira etapa, as origens obtidas diziam respeito a uma suposta origem desses alunos, tomadas do ponto central de cada setor centróides - enquanto que, nesta outra, as origens passariam a ser as próprias residências dos alunos. A execução desta etapa somente seria possível com 0 fornecimento dos endereços dos alunos pela Secretaria de Educação do Estado. Mesmo tendo-se empregado a primeira etapa como incentivo a essa cessão de dados, não foi possível se obter os endereços desta demanda, pois os mesmos negados pela Secretaria de Educação do Estado de São Paulo.

Como não foi possível obter os endereços da demanda das escolas estaduais, com 0 intuito de melhorar a análise dos resultados desta pesquisa, buscou-se verificar a aplicabilidade dos dados agregados na simulação da origem desses alunos. Para isso, obtiveram-se os endereços das crianças da rede municipal de ensino. Através destes dados, pôde-se medir a real distância de percurso envolvida (através de amostras) para, a partir de então, procederem-se às comparações do uso de dados agregados e desagregados, objetivando corroborar ou refutar os resultados obtidos na primeira etapa deste estudo.

O incremento dessas análises se dará à luz de informações, tais como restrições de percursos máximos admitidos para determinadas faixas etárias, adotadas no Brasil e no exterior. Com isso, será possível analisar a situação corrente e uma suposta "situação ideal", chegando-se a resultados requeridos como possíveis soluções de problemas de localização de futuras instalações e/ou realocação de serviços prestados. 


\subsection{Obtenção dos Dados}

Os dados de localização das escolas estaduais foram obtidos junto à Delegacia de Educação do Estado de São Paulo, os quais foram adicionados à rede viária empregada, através da digitalização direta com o mouse. Os dados do IBGE, obtidos junto ao escritório regional, já haviam sido digitalizados anteriormente em um trabalho do Departamento de Transportes da EESC-USP (SILVA et al., 1996). A localização das escolas municipais, bem como a localização dos alunos atendidos por estas, foram obtidos junto à Secretaria Municipal de Educação de São Carlos.

\section{- Procedimentos Adotados}

Com 0 auxílio de uma mesa digitalizadora 12"x12" e de um mapa da Prefeitura, na escala 1:10.000, partiu-se para a digitalização dos links da malha viária da cidade, tomandose 0 eixo central dos logradouros, nomeando-os segundo os mapas mais recentes obtidos. Nesta digitalização inicial, no entanto, não houve a preocupação de se definir minuciosamente os encontros de segmentos e nós, importantes para esse trabalho (SILVA \& WAERDEN, 1997). Esta importância advém do fato de que, para se localizar um determinado endereço no mapa digitalizado (através do processo de buscas do software), tem-se que ter o início e o final do link, demarcando o início e o fim de quadra, tornando-o inteligível ao programa. Assim, procedeu-se a uma nova digitalização para corrigir o mapa existente desta vez, na própria tela do computador, com o auxílio do mouse.

Com a malha viária digitalizada e corrigida, criou-se uma base de dados georeferenciada, cujo modelo é mostrado na TABELA 4.1. Esse banco de dados tinha como principal objetivo a localização dos endereços da demanda estudada, o qual seria efetivado com um sistema de busca executado pelo software, para posterior uso em suas rotinas. 
TABELA 4.1: Base de Dados de Endereços*

\begin{tabular}{|c|c|c|c|c|c|c|c|c|c|}
\hline UDOSL & & & & & & & & & x] \\
\hline ID & Length & Dir NAHE & [Left ZIP] & ht ZIP] & it Left] & d Left] & ht]] & $h \mid$ & rity \\
\hline 6418 & 0.12 & -1 RUA 15 DE NOVEMBRO & 1356 & 1356 & - & - & - & - & - \\
\hline 6453 & 0.10 & DAV SAD CARLOS & 1356 & 1356 & 2285 & 2359 & - & -. & - \\
\hline 6407 & 0.11 & 1 AV DR CARLOS BOTELHO & 1356 & 1356 & .. & - & - & .. & - \\
\hline 6452 & 0.10 & O AV SAD CARLOS & 1356 & 1356 & 2385 & 2461 & - & m & m \\
\hline 6532 & 0.12 & 1 RUA MAL DEODOAO & 1356 & 1356 & - & - & - & - & - \\
\hline 6539 & 0.09 & 1 RUA MAL DEODOFO & 1356 & 1356 & - & - & -- & - & - \\
\hline 6460 & 0.10 & DAV SAD CARLOS & 1356 & 1356 & 2085 & 2163 & - & -- & 1 \\
\hline 6518 & 0.11 & 1 RUA PE TEIDEIRA & 1356 & 1356 & *. & - & - & w & - \\
\hline 6429 & 0.11 & 1 RUA SAO SEBASTLAO & 1356 & 1356 & m & $=$ & - & m & - \\
\hline 6459 & 0.10 & O AV SAO CARLOS & 1356 & 1356 & 2205 & 2259 & - & -. & 1 \\
\hline 6517 & 0.00 & -1 RUA DA ALEXANDAINA & 1356 & 1356 & - & - & - & - & - \\
\hline 6519 & 0.09 & -1 RUA PE TEIDEIRA & 1356 & 1356 & -. & - & -- & $\ldots$ & - \\
\hline 6465 & 0.10 & 1 RUA DA ALEXANDAINA & 1356 & 1356 & .. & - & - & $w$ & - \\
\hline 6470 & 0.10 & 1 RUA SAO JQAQUIH & 1356 & 1356 & $m$ & $=$ & - & $m$ & $m$ \\
\hline 6430 & 0.09 & 1 RUA SAO SEBASTIAO & 1356 & 1356 & - & - & - & - & - \\
\hline 6464 & 0.10 & -1 RUA DA ALEXANDAINA & 1356 & 1356 & -. & - & -- & - & - \\
\hline 6419 & 0.10 & -1 RUA 15 DE NOVEMBRO & 1356 & 1356 & - & - & - & -- & - \\
\hline 6494 & 0.10 & 1 RUA DA ALEXANDRINA & 1356 & 1356 & .. & - & .. & .. & -. \\
\hline 6469 & 0.10 & 1 RUA SAO JQAQUIH & 1356 & 1356 & m & - & - & m & 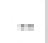 \\
\hline 6493 & 0.10 & 1 RUA SAO JOAQUIH & 1356 & 1356 & - & - & - & - & - \\
\hline 6408 & 0.10 & 1 AV DR CARLOS BOTELHO & 1356 & 1356 & - & - & -- & -. & - \\
\hline 6498 & 0.10 & -1 RUA DA ALEXANDFINA & 1356 & 1356 & - & - & - & - & - \\
\hline 6502 & 0.11 & 1 RUA SAD JOADUIM & 1356 & 1356 & .. & - & t & 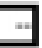 & - \\
\hline
\end{tabular}

(*) Ainda Não Concluída

A elaboração dessa base de dados ainda está em andamento (a numeração dos endereços está sendo colocada). Pela proximidade da data limite para conclusão deste trabalho e, principalmente, por não se ter obtido os dados desagregados junto à Secretaria de Educação de São Paulo, não se esperou a total conclusão desta base de dados para se proceder às análises². Trabalhou-se com o que se tinha até então: os nomes dos logradouros. Com os nomes dos logradouros em um banco de dados, é possível localizar o cruzamento de duas vias. Partiu-se, então, para a busca dos endereços através da localização do cruzamento mais próximo da residência de cada aluno. Caso a base estivesse concluída, a busca feita pelo software poderia ser a própria residência do aluno, e não apenas o cruzamento mais próximo.

\footnotetext{
${ }^{2}$ A alimentação da base de dados está sendo feita em equipe, a qual é composta por dois bolsistas de iniciação científica, três mestrandos e uma doutoranda, envolvidos em diferentes projetos, o que resultou no atraso de sua conclusão.
} 
Empregaram-se também os setores do censo de 1991, digitalizados em uma camada de áreas, posteriormente, exportados como pontos (centróides). Os dados de localização das escolas também foram registrados em camadas de pontos, ficando uma restrita às escolas que existiam e atendiam à demanda antes da reorganização escolar, perfazendo um total de 29 pontos, e outra, contendo as instalações que passaram a atender exclusivamente às crianças de $1^{\mathrm{a}}$ à $4^{\mathrm{a}}$ séries, num total de 18 pontos.

Utilizando-se de dispositivos do software, "conectaram-se" esses atributos, de camadas diferentes, à rede (malha viária), partindo-se para o cálculo das "distâncias reais" entre os pontos de oferta e demanda. Essa conexão nada mais foi que o reconhecimento do nó mais próximo da malha viária dos demais pontos e, conseqüentemente, de seus atributos, pertencentes a camadas diferentes (comando Edit Fill-TAG).

\subsubsection{Justificativa para os Dados Empregados}

Como já mencionado, o principal motivo de se ter trabalhado com dados populacionais agregados, oriundos do censo de 1991 do IBGE, foi o de não se conhecer os endereços dos alunos da rede estadual de ensino. Desta forma, partiu-se do pressuposto de que a origem destes alunos se daria nos centróides dos setores censitários, utilizando-se os resultados do censo de 1991, já digitalizados em uma camada de áreas. O software dispõe de recursos que permitem "exportar" esses dados de atributos de área para pontos. Cada ponto exportado é o centróide de uma área, da qual advém todas as informações alfanuméricas. Essas informações perfazem um total de 291 campos, coletados pelo IBGE, contendo informações da localização (código do município, do distrito, do setor, etc.) e de dados socioeconômicos da população (renda, escolaridade, etc.). A utilização dessas variáveis, de modo georeferenciado, permite a criação de cenários (comparáveis visualmente através de mapas temáticos), os quais também serão empregados neste estudo.

Inicialmente, pensou-se em trabalhar apenas com dados referentes à Reorganização Escolar Estadual, de 1995. Com o desenrolar das tarefas realizadas no trabalho, chegou-se à conclusão de que os endereços dos alunos atendidos pelo Estado não seriam obtidos, 
fazendo-se com que a abordagem se expandisse, abrangendo, em outra instância, as crianças de mesma faixa etária, atendidas pelo Município. Com isso, pôde-se proceder a análises mais precisas dos custos envolvidos nesta classe. Desta forma, as abordagens feitas da rede estadual, com o uso de dados agregados, foram corroboradas pela comparação dos resultados obtidos com os cálculos dos custos desagregados ("reais"), através de amostra de alunos das escolas do Município. Esta análise será mostrada graficamente, através da distribuições de freqüências destes dados e através da comparação entre estas médias amostrais, aplicando-se testes de hipóteses (ANEXO A) para verificar a aplicabilidade destes dados agregados. Tomou-se o cuidado de agregar os alunos da linha divisória dos setores para o centróide que lhes estivesse mais próximo. Para o emprego destes dados, assumiu-se a hipótese de que toda a classe estudantil envolvida no estudo seria recebida pela rede pública de ensino, como de direito, convergindo, assim, toda a demanda para escolas públicas.

Um último comentário relativo aos dados empregados se refere à medida de distâncias entre pontos. Trabalhou-se com a distância em rede, ao invés de se trabalhar simplesmente com a distância euclidiana, pois se percebeu uma diferença de aproximadamente $23 \%$ entre essas médias ${ }^{3}$. Em princípio, essa diferença não teria tanto impacto, haja vista estar-se trabalhando com centróides, ou seja, por estar partindo-se já de uma aproximação. No entanto, como se tinha interesse em calcular o efetivo deslocamento de, pelo menos, parte da demanda, a aplicação da métrica euclidiana não daria a precisão desejada. Sabe-se, no entanto, que esta métrica poderia ter sido ajustada por um fator de correção, como visto na bibliografia consultada (Capítulo 2).

\subsection{Software e Recursos do Software Empregados}

Por se desejar utilizar os Sistemas de Informações Geográficas como ferramenta de apoio às análises do caso em estudo, escolheu-se um programa que melhor se adequasse ao problema e que estivesse disponível. O software foi o TransCAD, versão 3.0 for Windows

\footnotetext{
3 Para se chegar a esse resultado, tomou-se um ponto central da cidade (escolheu-se um centróide que estivesse mais próximo do centro geométrico da cidade) e se efetuou o cálculo das distâncias do demais centróides (num total de 123 centróides), em rede e em linha reta. Os cálculos das análise dos parâmetros estatísticos são mostrados no ANEXO B.
} 
(CALIPER, 1996). Esta opção se deveu ao fato de que o mesmo, além de funcionar como um banco de dados, capaz de suportar um grande número de informações, também possui rotinas especialmente criadas para o planejamento em transportes, cujo uso depende do objetivo que se queira atingir.

Como o trabalho desenvolvido envolve distribuição e alocação, escolheu-se 0 módulo desse software que trata de logística. Dentre as possíveis alternativas apresentadas no módulo, quatro mais se aproximaram da abordagem adotada neste trabalho. Em alguns casos, para que se tivesse um melhor resultado, fez-se a junção de algumas dessas rotinas, ou seja, aplicaram-se os resultados de uma rotina para alimentar outra, obtendo-se, assim, um resultado mais próximo do real. As rotinas escolhidas possuem classes particulares de algoritmos, como mostradas a seguir:

- 1a ROTINA: Modelos de Fluxo em Rede

São modelos que dão soluções ótimas para muitos tipos de fluxo em rede, combinando problemas, onde produtos ou serviços devem ser associados de um conjunto de pontos de oferta para outros, de consumo (CALIPER, 1996). Esta rotina se subdivide em três. A primeira delas é utilizada quando se deseja ligar apenas um ponto de oferta para um outro, de consumo, dando-se a ligação "um para um". A segunda liga cada ponto de oferta a vários de demanda, ou, cada ponto de demanda a vários de oferta, produzindo uma matriz que mostra os fluxos resultantes. A terceira, e última, faz o mesmo tipo de ligação que a segunda rotina, porém levando-se em consideração a capacidade dos segmentos (links) na rede. Como o problema em estudo envolve várias origens (escolas) para vários destinos (alunos), não importando a capacidade dos links, tomou-se a segunda opção como a mais adequada do grupo.

Para essa opção, de início, o software assume que o sistema é "balanceado". Admitir um sistema como balanceado, significa dizer que o somatório das capacidades das instalações ofertadas é igual à quantidade demandada por este serviço. Desta forma, assumiu-se o sistema como balanceado, procedendo-se às respectivas medidas de ajuste 
para que a rotina pudesse ser aplicada, ou seja, ajustando-se as quantidades de demanda à capacidade de atendimento dos pontos de oferta, redistribuindo esta demanda de modo proporcional (maiores detalhes serão mostrados no próximo capítulo). O software pede ainda uma matriz de custos como dado de entrada (também gerada por seu intermédio), onde 0 custo envolvido é a distância percorrida. O produto desta rotina é uma matriz de fluxos, que mostra as quantidades alocadas para cada estabelecimento, de maneira a resultar em um menor custo para o sistema, respeitando-se as capacidades destes. Tem-se a ressalva de que, quando a capacidade de um dos integrantes do sistema é atingida, a rotina aloca a porção restante da demanda do atual ponto para o mais próximo.

Segundo Caliper (1996), o problema acima mencionado também é conhecido como "Hitchcock problem" (Hitchcock foi a primeira pessoa que, originalmente, formulou 0 problema, em 1941). O TransCAD usa o método simplificado de programação linear para este tipo de análise. O algoritmo toma como solução inicial um número mínimo de nós a serem "carregados", verificando se a solução pode ser ainda melhorada. Pára de carregar quando a solução ótima é encontrada, ou seja, quando se conseguiu ligar o nó de origem ao de destino utilizando-se o número mínimo possível de links.

Essa rotina dará, além das matrizes de fluxos de origem e destino, dados que, analisados estatisticamente, determinarão a variação dos custos de deslocamento envolvidos com a reorganização escolar, fazendo-se a comparação dos custos anteriores e posteriores. Para tanto, será admitida a situação ótima, em que a alocação dos alunos às escolas se dá de forma a gerar o menor custo para o sistema (situação dada pela rotina).

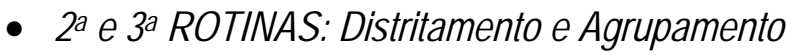

Estas rotinas pertencem a um mesmo grupo, envolvendo a criação de blocos baseados na proximidade ou similaridade. Dão suporte a aplicações que lidam com serviços de venda, marketing, redistribuição política, etc. A TABELA 4.2 apresenta as principais diferenças entre ambas as rotinas. 
Para a rotina de distritamento (ou particionamento), precisa-se gerar, além da matriz de custos, uma matriz de adjacência, que contém informações do relacionamento espacial entre as zonas (aqui, setores censitários), como contigüidade e compacidade das zonas (a FIGURA 4.2 representa estes conceitos de forma mais simples). Estas rotinas também podem levar em conta o balanceamento entre zonas, consistindo na divisão de regiões que se assemelhem e que contenham características comuns (pode-se balancear regiões por áreas, população, etc.).

TABELA 4.2 - Diferenças entre as Rotinas de Particionamento e Agrupamento

\begin{tabular}{ll}
\hline Particionamento (ou Distritamento) & Agrupamento \\
\hline $\begin{array}{l}\text { Usado quando se deseja criar áreas, } \\
\text { compostas por outras menores existentes }\end{array}$ & $\begin{array}{l}\text { usado quando se deseja agrupar } \\
\text { características numa camada, baseadas } \\
\text { na distância ou tempo de viagem entre as } \\
\text { mesmas }\end{array}$ \\
\hline Usa apenas camadas de áreas & usa camada de pontos, linhas ou áreas \\
\hline $\begin{array}{l}\text { Tem-se que especificar um ponto inicial } \\
\text { para cada grupo }\end{array}$ & $\begin{array}{l}\text { não é preciso especificar um ponto inicial } \\
\text { para os grupos }\end{array}$ \\
\hline Sempre cria grupos contíguos & pode criar grupos não-contíguos \\
\hline $\begin{array}{l}\text { Pode ser usado para criar grupos com } \\
\text { carregamentos balanceados }\end{array}$ & $\begin{array}{l}\text { pode restringir o carregamento para um } \\
\text { certo nível, mas não garante o } \\
\text { balanceamento entre grupos }\end{array}$ \\
\hline
\end{tabular}

Fonte: Caliper, 1996, Routing and Logistics with TransCAD, p. 69.

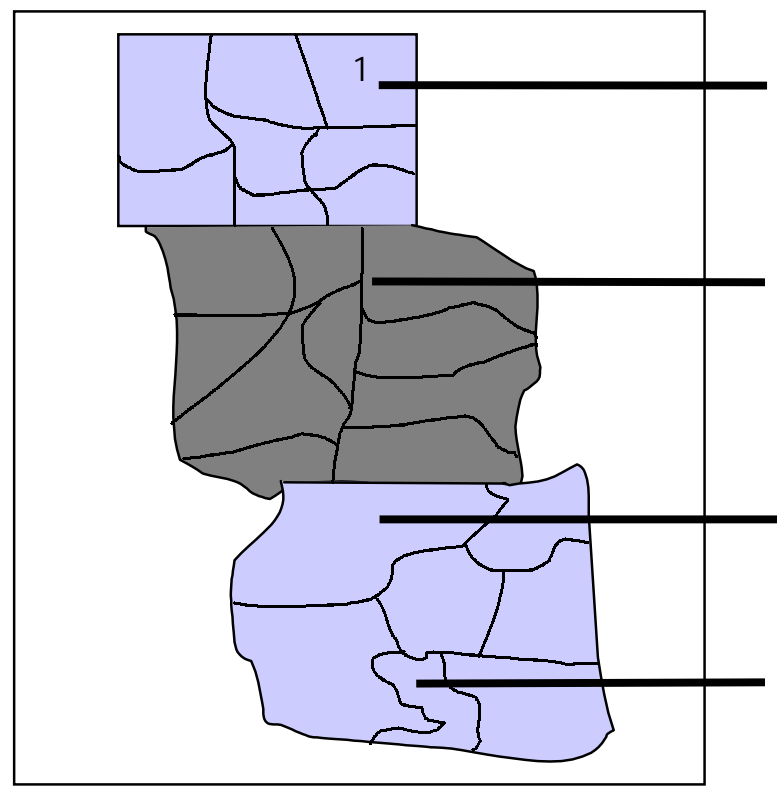

Esta zona é compacta

O distrito em cinza é contíguo (as zonas que o compõem são conectadas ou adjacentes umas às outras)

O distrito em azul não é contíguo (suas zonas não são conectadas ou adjacentes umas às outras)

Esta zona é menos compacta que a zona 1 (a razão perímetro sobre área é maior que no caso 1)

FIGURA 4.2 - Conceitos de Compacidade e Contigüidade 
Para a rotina de agrupamento, precisa-se gerar uma matriz de custos, que indica as distâncias entre os pontos que se queiram agrupar (matriz quadrada) ${ }^{4}$. Também como entrada, esta rotina pede que se dê o tamanho de cada agrupamento, ou seja, o limite de capacidade de cada um. A partir daí, os agrupamentos são feitos respeitando-se a capacidade máxima dada.

Observando-se as restrições impostas por essas rotinas - já observadas na TABELA 4.2, parte-se dos agrupamentos para a definição dos pontos iniciais das divisões zonais ("sementes"), aplicando-se estes resultados como dados de entrada na rotina de distritamento, já que esta precisa de um ponto inicial para cada agrupamento. Ressalta-se que a aplicação do agrupamento (para gerar as sementes) se deu por opção, a qual também é sugerida no manual do software.

Estas rotinas serão aplicadas para gerar o "cenário hipotético", ou seja, para mostrar as "sementes" como supostas "escolas ideais" para a população em análise, mostrando-se a cobertura (área de atendimento) de cada uma, baseada na população estudada.

- $4^{a}$ ROTINA: Modelos de Localização de Instalações

Esta rotina consiste em identificar qual ou quais as localizações mais adequadas de um determinado serviço, dentre um dado conjunto de alternativas. Permite ainda, que sejam dadas alternativas de realocação de serviços com instalações já existentes. Isso facilita a abordagem que pode ser feita quando se deseja saber se a exclusão ou inclusão de uma determinada instalação será mais ou menos benéfica que outra. Em geral, o objetivo de se localizar tais instalações é o de se aumentar o nível de serviço, o qual pode se restringir à minimização dos custos médios, à minimização do máximo custo observado ou à maximização do lucro ${ }^{5}$. Essa rotina envolve outras matrizes, que, por não fazerem parte da abordagem adotada neste trabalho, serão desprezadas. Será utilizada a mesma matriz de custos, anteriormente empregada.

\footnotetext{
4 Todas as matrizes podem ser criadas pelo software e funcionam como dados de entrada.

${ }^{5}$ Neste trabalho, o lucro não será levado em consideração.
} 
A alocação da demanda, neste caso, não leva em consideração a capacidade dos estabelecimentos. Sem a preocupação de um limite de capacidade, é possível se ter uma representação que forneça melhores alternativas para a população, aumentando o nível de serviço. Esse limite de capacidade é a maior diferença entre a primeira rotina citada e esta6. O que aqui pode ser feito, para representar melhor a situação, é a atribuição de um peso para esta distribuição de demanda (opção dada pela rotina), no caso, uma das variáveis do IBGE. A justificativa para se empregar este peso é o fato de se estar trabalhando com dados agregados, cuja representação é dada em termos de uma variável escolhida. Se não se considerar este peso, não se estará considerando a variável e, conseqüentemente, não se estará representando a demanda estudada; em outras palavras, ao se desconsiderar o peso, a rotina faz a distribuição destes "pontos de demanda" sem nenhum vínculo com a variável empregada, representante da demanda, levando-se em consideração apenas a distância entre os pontos de oferta e os supostos pontos de demanda.

Este modelo também será utilizado para obtenção da variação dos deslocamentos antes e após a reforma escolar, os quais também poderão ser comparados aos primeiros resultados obtidos na primeira rotina.

Todas as rotinas, anteriormente descritas, algumas das quais serão aplicadas no estudo de caso (próximo capítulo), estão sintetizadas a seguir (TABELA 4.3), com exemplos práticos de aplicação.

\footnotetext{
${ }^{6}$ A primeira rotina distribui o fluxo de acordo com a capacidade disponível de oferta, já que considera o balanceamento do sistema. Isso permite trabalhar levando-se em consideração a capacidade de cada instalação.
} 
TABELA 4.3 - Rotinas Mencionadas no Método com Aplicações Práticas

\begin{tabular}{|c|c|c|}
\hline GRUPO & ROTINA & EXEMPLO PRÁTICO DE APLICAÇÃO \\
\hline $\begin{array}{l}\text { 1. Modelos de } \\
\text { Fluxo em Rede }\end{array}$ & $\begin{array}{l}\text { (1.2 Ligação "um para vários" } \\
\text { ou "vários para um" } \\
\text { 1.3 Ligação "um para vários" } \\
\text { ou "vários para um" } \\
\text { levando em considera- } \\
\text { ção a capacidade do } \\
\text { link }\end{array}$ & $\begin{array}{l}\text { Estabelecer a ligação de funcionários } \\
\text { que prestam serviços de limpeza a } \\
\text { pontos solicitantes, de modo a resultar } \\
\text { em uma melhor solução para o } \\
\text { sistema, ou seja, escolhendo-se, para } \\
\text { cada ponto de solicitação, o } \\
\text { funcionário possivelmente mais } \\
\text { próximo a este (toma-se o cuidado de } \\
\text { não deixar um funcionário ficar } \\
\text { consideravelmente mais distante do } \\
\text { ponto a servir que outro). } \\
\text { Fazer a alocação de vans, que fazem } \\
\text { entrega de leite, para várias padarias, } \\
\text { respeitando-se o limite de } \\
\text { carregamento das vans. } \\
\text { Distribuição de bens em uma cidade } \\
\text { com alto grau de congestionamento } \\
\text { nas vias. }\end{array}$ \\
\hline $\begin{array}{l}\text { 2. Modelos de } \\
\text { Agrupamento e } \\
\text { Particionamento }\end{array}$ & $\begin{array}{l}\text { 1.1 Agrupamento } \\
1.2 \text { Particionamento }\end{array}$ & $\begin{array}{l}\text { Agrupar áreas que apresentem } 0 \\
\text { mesmo tipo de doença (para controle } \\
\text { de epidemias). } \\
\text { Definir o tamanho de zonas eleitorais } \\
\text { para garantir número semelhante de } \\
\text { eleitores por zona. }\end{array}$ \\
\hline $\begin{array}{l}3 \text { Modelos de } \\
\text { Localização de } \\
\text { Instalações }\end{array}$ & - & $\begin{array}{l}\text { Escolha da melhor localização de } \\
\text { mais uma loja de fast food, tomando } \\
\text { por base a demanda de } 10 \text { a } 14 \text { anos. } \\
\text { Neste caso, será escolhida a região } \\
\text { (ou ponto) que apresentar o menor } \\
\text { percurso médio de deslocamento para } \\
\text { essa população (supondo-se os } \\
\text { mesmos níveis de renda e consumo } \\
\text { para a demanda). }\end{array}$ \\
\hline
\end{tabular}




\subsection{Método a Ser Aplicado na Pesquisa (Sumário de Atividades)}

Para que melhor se compreenda as atividades, até agora seguidas no método, fezse a descrição sumária e ordenada de todas estas, resultando numa seqüência de 19 passos, como é mostrada a seguir.

1. Obtenção de mapas atualizados da cidade.

2. Obtenção do mapa de divisão setorial junto ao IBGE.

3. Coleta de informações das instalações que se queiram analisar (dados de localização, capacidade, projetos, etc.).

4. Transferência dos dados obtidos nos ítens anteriores para o software TransCAD, por meio de digitalização e/ou digitação.

5. Transformação dos atributos de área (dos setores censitários do IBGE) para pontos, através de sua exportação (feita pelo programa), obtendo-se, assim, os centróides destas áreas. Esta etapa é importante quando não se conhece o real posicionamento da demanda, trabalhando-se apenas com os dados do censo demográfico, de forma agregada.

6. Caso se tenha o real posicionamento da demanda, cria-se um banco de dados que contenha informações pertinentes, respeitando-se o formato do arquivo de busca do software (a numeração vem antes do nome do logradouro, por exemplo) e a grafia. Para este caso, a base de dados da cidade já deve estar completa, contendo informações de logradouros, números e CEP (Código de Endereçamento Postal). Antes da criação da base de dados da cidade e do banco de dados que contém os endereços da demanda, é aconselhável observar os exemplos existentes no tutorial do programa para deixá-los com os mesmos formatos.

7. Trabalhando-se ainda com dados reais (item anterior), identificar quais os endereços que não foram localizados no processo de busca efetuado pelo programa. Se for necessário, consertam-se os possíveis erros de digitação e repete-se o processo até que se encontrem todas as localizações. 
8. Cálculo da matriz de custos (distância, tempo, etc.) entre as origens e os destinos, a qual pode ser construída pelo software. Esta matriz expressa os custos entre cada par de origem e destino.

9. Cálculo da matriz de custos (distância, tempo, etc.) entre as zonas analisadas - no caso de se trabalhar com dados agregados, os custos entre os setores censitários.

10. Cálculo da matriz de adjacência entre os setores censitários, também gerada pelo programa.

11. Balanceamento da demanda de acordo com a capacidade do sistema, isto é, de acordo com a capacidade das instalações 7 . Esta etapa pode ser executada com o auxílio de uma planilha eletrônica.

12. Cálculo da matriz de fluxos com 0 auxílio da primeira rotina ("um para vários ou vários para um"). Caso os dados de localização sejam desagregados, o cálculo desta matriz indicará a melhor redistribuição da demanda. Se os dados empregados forem agregados, esta matriz indicará a melhor alocação desta demanda, de forma agregada. Para este último caso, terá que se admitir a situação ótima de distribuição criada por esta rotina para a obtenção dos custos médios.

13. Multiplicação da matriz de fluxo pela matriz de custos (item 8), para a obtenção do custo médio observado. Este custo médio leva em consideração a capacidade das instalações.

14. Determinação da quantidade de agrupamentos que se quer fazer (para futuras análises, recomenda-se o mesmo número de instalações existentes).

15. Localização dos pontos iniciais de agrupamentos (sementes), dado pela rotina de agrupamento, dando-se um valor de capacidade para cada agrupamento (pode-se partir da capacidade média das instalações até se encontrar um valor compatível). Este valor de capacidade, dado como entrada para a rotina, é entendido, pelo programa, como sendo 0 valor máximo de capacidade que cada agrupamento pode ter - na aplicação, é o valor máximo de demanda admitido para cada instalação.

16. Verificar a aplicabilidade das "sementes" como pontos iniciais de divisões para os distritos que serão criados. Se os setores possuírem características muito diferentes, as sementes

\footnotetext{
7 Este item só será necessário se os dados forem agregados, pois é necessário fazer a redistribuição da demanda de acordo com a capacidade das instalações e de modo proporcional à variável do censo adotada, já que esta representa a população analisada. Caso se esteja trabalhando com dados reais, esta etapa somente será necessária se, no processo de busca, todos os endereços não forem localizados. Neste caso, deve-se proceder à diminuição das capacidades das instalações, proporcionalmente ao número de endereços não encontrados.
} 
geradas podem não ser contíguas, podendo-se localizar muito próximas e/ou coladas umas das outras. Essa situação não é aceita pela rotina de particionamento, exigindo-se a reespecificação dos pontos iniciais. Esta reespecificação pode tomar por base um mapa temático de densidades (feito na camada dos centróides) da variável que se adotou.

17. Para se proceder ao particionamento (agrupamento da população dos setores censitários em igual número de instalações), além dos pontos iniciais (sementes adotadas), aplicamse também as matrizes de custos e adjacência (item 9 e 10, respectivamente). Esta divisão pode ser aplicada em análises posteriores - para se saber a atual cobertura dos serviços prestados - e como auxílio na criação dos cenários hipotéticos, empregados na última rotina.

18. Criação de cenários hipotéticos, através da indicação de possíveis localizações para as novas instalações que se queira construir. Nesta etapa, deve-se usar a ferramenta de seleção do software para identificar quais as instalações candidatas e quais as já existentes, utilizadas para a execução da última rotina (localização de instalações). Neste caso, deve-se gerar uma nova matriz de custos (distância, tempo, etc.) entre as origens, das quais as instalações candidatas também farão parte, e os destinos. Caso se trabalhe com dado agregados, tem-se que especificar qual a variável levada em consideração (nesta rotina, esta variável é dada como um peso para a distribuição da demanda).

19. Se os dados de demanda aplicados forem agregados, a última rotina também servirá como outra forma de obtenção dos custos médios ${ }^{8}$, desta vez, calculando um custo médio que não considera a restrição de capacidade das instalações, já que seu objetivo é o de aumentar o nível de serviço. Para isto, deve-se supor que todas as instalações são existentes, não existindo nenhuma instalação candidata. Deve-se sempre empregar a matriz de custos que expresse a situação que se deseja analisar - neste caso, deve-se usar a matriz do item 8.

\footnotetext{
${ }^{8}$ A rotina que trata de modelos de fluxos em rede também foi empregada com este fim.
} 


\section{CAPÍTULO 5}

\section{ESTUDO DE CASO}

Neste capítulo, apresenta-se o caso estudado, inicialmente com uma breve descrição do local onde se desenvolveu a pesquisa e da população estudada. Em seguida, faz-se menção à demanda das redes estadual e municipal de ensino, com a descrição de algumas características e de alguns procedimentos adotados dentro do método empregado.

\section{1 Área de Estudo}

A atual pesquisa se desenvolveu na cidade de São Carlos, situada na região central do estado de São Paulo, a qual está a 230km da capital (FIGURA 5.1). Este município possui altitude média de 850m e está localizado às margens da Rodovia Washington Luiz (SP-310), o que the permite acesso a várias cidades do estado.

Tida atualmente como um pólo industrial-tecnológico, São Carlos é uma cidade que, nos últimos anos, vem sofrendo altas taxas de crescimento. Deve-se tal crescimento às transformações significativas em sua economia, anteriormente baseada na agricultura e pecuária. Segundo a última contagem populacional, feita em 1996 pelo IBGE, o município de São Carlos conta com 175.517 habitantes, dos quais 164.103 pertencem à área urbana. Se comparado ao último censo (1991), onde a população do município era de 158.221, chegase a um aumento de 10,93\% (2,10\%a.a.) - ficando o crescimento urbano em 12,74\% (2,43\%a.a.). Nota-se uma discrepância ainda maior quando este crescimento é comparado à taxa nacional observada nos anos 90, em torno de 1,3\% a.a. (IBGE, 19971).

\footnotetext{
1 apud VEJA (1997)
} 

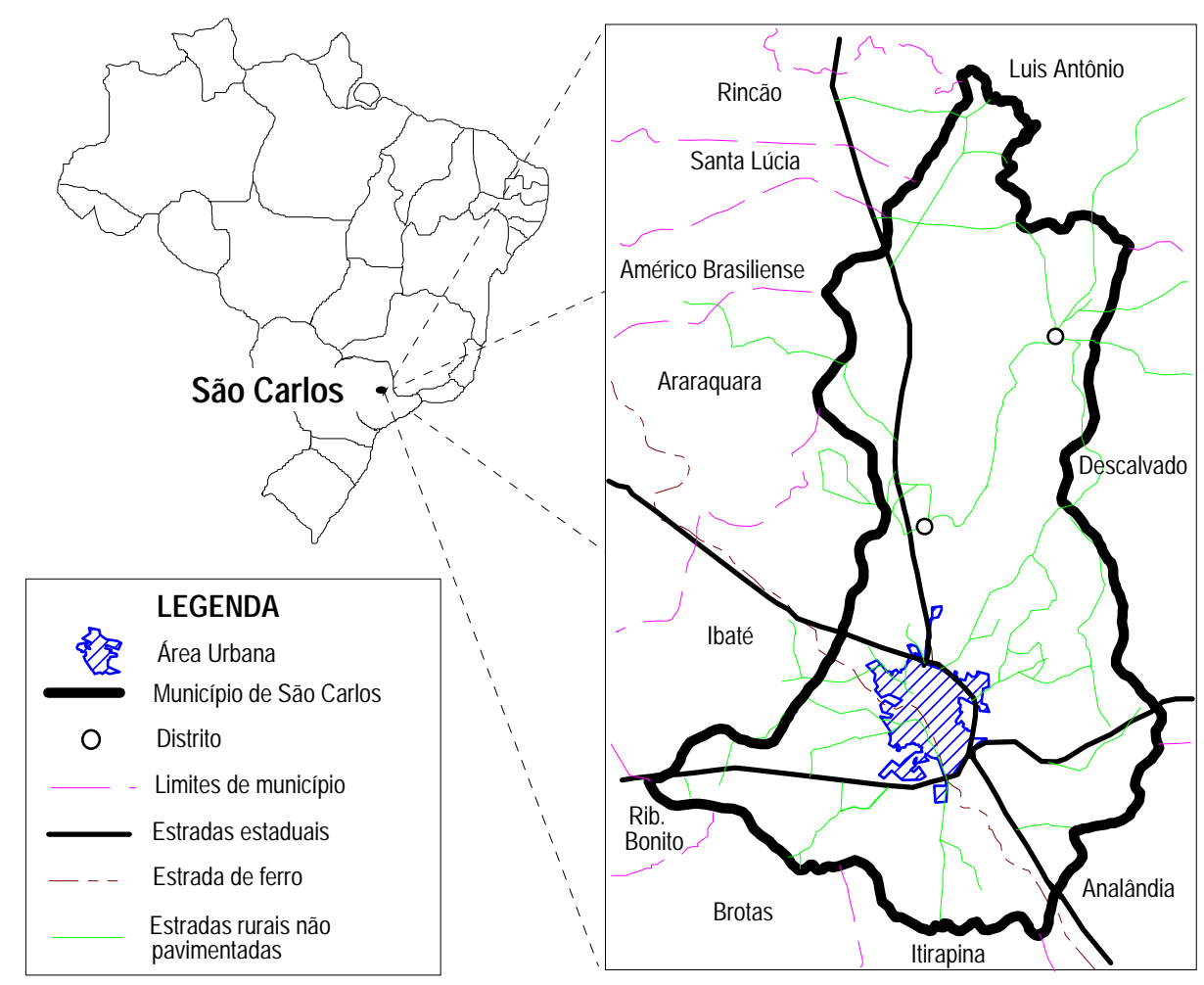

FIGURA 5.1 - Localização Geográfica do Município de São Carlos

Fonte: VIVIANI et al., 1994.

\subsection{População Estudada}

Este estudo se ateve à demanda por escolas públicas de $1^{\text {a }}$ a $4^{\text {a }}$ séries (ensino fundamental).

\subsubsection{Características Gerais}

Segundo uma breve análise dos dados fornecidos pela Delegacia de Ensino, comprovou-se a enorme participação do Estado como órgão responsável pelo ensino fundamental, chegando a custear $80 \%$ dos alunos (o Município colabora com cerca de 7\%, ficando o percentual restante para a rede particular). Mesmo com as educações infantil e de $1^{0}$ grau passando a ser gerenciadas pelo Município, de acordo com a CONSTITUIÇÃO FEDERAL de 1988, o que se observa é que, em São Carlos, a participação efetiva do 
Município apenas se dá na alfabetização (crianças de 3 a 6 anos). Segundo o GEIPOT (1995), o Estado de São Paulo apresenta uma situação atípica em relação aos demais estados brasileiros. De acordo com a Delegacia de Ensino local, a municipalização é gradativa e lenta, mas existem projetos de novas construções de escolas já sendo implementados em locais mais densos e distantes, efetivando-se a parceria do Município, junto ao Estado, com a divisão e o repasse dos gastos já nessas novas instalações.

Quanto à restrição de caminhada, segundo a Delegacia de Ensino local, não existe um limite rígido de quilômetros que restrinja o percurso máximo admitido. Segundo este órgão, tenta-se fazer com que a caminhada dos alunos não exceda a $2 \mathrm{~km}$ - há uma maior preocupação com os deslocamentos das crianças menores.

Os gastos com o transporte escolar ficam sob a responsabilidade do Município, mesmo sendo a maior parte das escolas rurais e da área urbana, que atendem à demanda rural, estaduais. O Município tem uma cota mensal que deve ser aplicada na educação fundamental. Como quem custeia essa despesas em São Paulo é, praticamente, o Estado, 0 Município se obriga a empregar essa verba no transporte escolar, fretando ônibus para transportar as crianças mais distantes (zona rural) e os alunos que ficaram mais distantes após a reorganização escolar. Segundo a Secretaria de Educação do Município, há um gasto mensal de $\mathrm{R} \$ 350$ mil com o transporte escolar, pagos a empresas de transporte, contratadas pelo Município, as quais perfazem um total de 32 linhas. O percurso médio diário é de $9.000 \mathrm{~km}$, com 3.000 crianças transportadas. Existe um trabalho de pesquisa, desenvolvido na Universidade Federal de São Carlos, que objetiva a otimização dessas rotas (ALMEIDA, 1997).

\subsubsection{Características da Reorganização Escolar da Rede Estadual de Ensino}

Após a reorganização escolar de 1995, das 18 escolas públicas que atendem à demanda pelo ensino fundamental, 16 são mantidas pelo Estado, ficando o Município com apenas duas. Antes da reorganização, esta demanda era atendida por 29 escolas, das quais, 27 eram estaduais. 
O estudo de caso assumiu, para a abordagem inicial, dois cenários distintos: antes da reforma escolar, atendendo o sistema a uma demanda de 11745 alunos, e após esta, com 11720 alunos matriculados. Em ambos os casos, o sistema contou com duas escolas mantidas pelo Município. A FIGURA 5.2 representa as situações mencionadas.

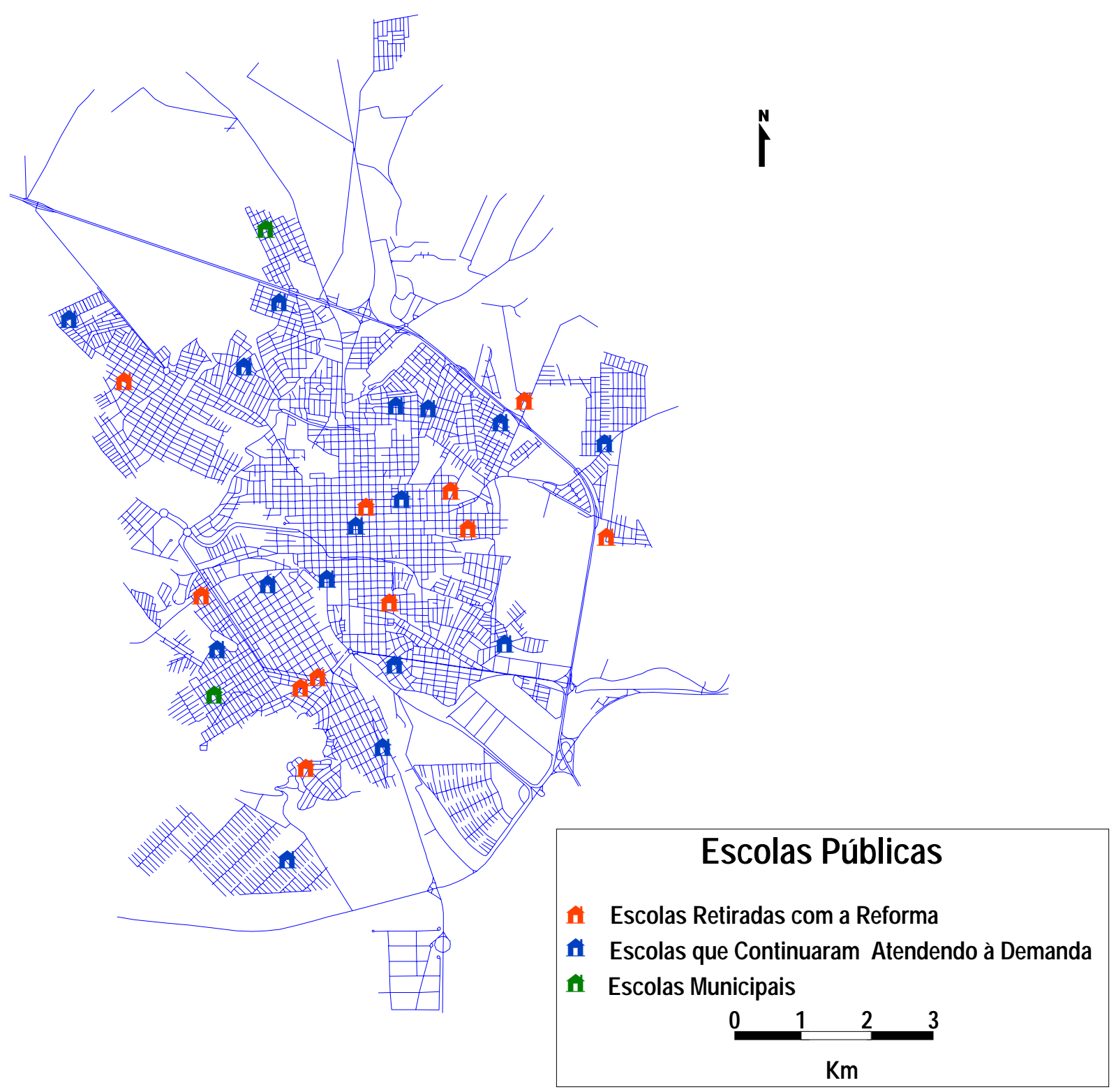

FIGURA 5.2 - Distribuição Espacial das Escolas Públicas, com Séries de 1ª̀ à - Situação Anterior e Posterior à Reforma Escolar de 1995. 


\subsubsection{Características da Rede Municipal de Ensino}

A área urbana de São Carlos conta com vinte e duas escolas municipais que atendem à demanda por escolas pré-primárias, abrangendo crianças com faixa etária entre 3 e 6 anos, e apenas duas escolas que possuem 0 ensino fundamental ( $1^{\mathrm{a}}$ a $4^{\mathrm{a}}$ séries) - estas últimas serão as consideradas neste estudo.

Como observado anteriormente, a Municipalização tem por objetivo repassar todos os gastos para o Município. Por São Paulo ser um caso atípico, a participação do Município no ensino fundamental (primeiro grau) se efetiva através de gastos com o transporte escolar para esta mesma demanda que, em sua grande maioria, é atendida pelas escolas estaduais.

Ao contrário da rede estadual, que não pôde fornecer os endereços de seus alunos, obtiveram-se os endereços das crianças da rede municipal de ensino, para todos os níveis de escolaridade. De posse destes endereços, foi possível analisar o "real deslocamento" das crianças de $1^{\mathrm{a}}$ à $4^{\mathrm{a}}$ séries (através de amostras), das escolas municipais, as quais atendem ao mesmo nível que as estaduais. As FIGURAS 5.3 e 5.4 mostram as localizações das escolas municipais, dos pontos de demanda selecionados e os respectivos setores censitários empregados na comparação de dados agregados e desagregados. A análise dos dados de localização das amostras permitiu comparar o uso de dados agregados e desagregados, justificando a aplicação de desagregados, adotados nesta pesquisa (ANEXO A). 


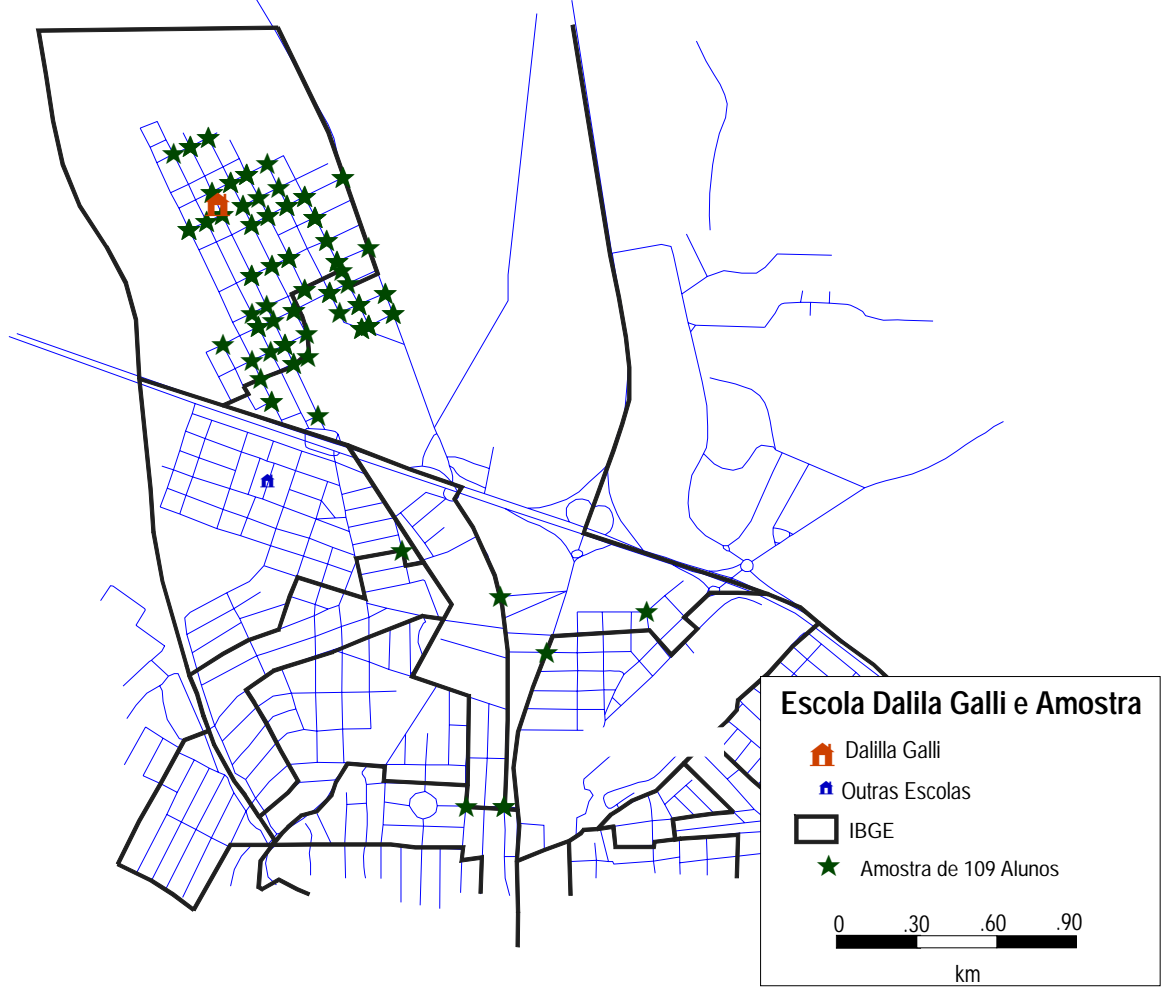

FIGURA 5.3 - Setores Censitários que Contêm a Amostra de 109 Alunos da Escola Municipal Dalila Galli.

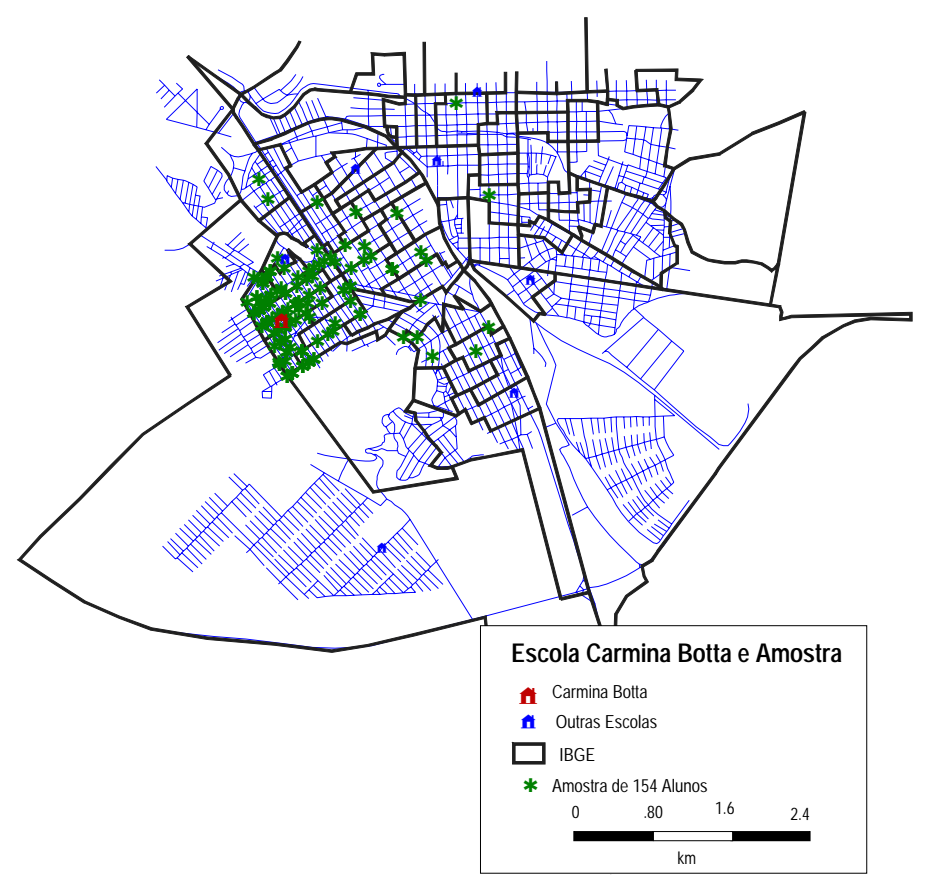

FIGURA 5.4 - Setores Censitários que Contêm a Amostra de 154 Alunos da Escola Municipal Carmina Botta. 


\section{- Medidas de Ajuste de Dados}

A faixa etária estipulada pelo MEC, como ideal para crianças de $1^{\mathrm{a}}$ à $4^{\mathrm{a}}$ séries, vai de 7 a 10 anos, respectivamente. Como o censo populacional realizado pelo IBGE não possui uma variável específica para esse intervalo, algumas medidas de aproximação tiveram que ser adotadas. Inicialmente, assumiu-se 0 intervalo dado pelo IBGE, o qual envolvia "crianças alfabetizadas de 5 a 9 anos" (variável número 99). Para este caso, as crianças de 5 e 6 anos (fora da especificação do MEC) tomariam o lugar das de 10. Mesmo com a correção da população infantil para o ano de 1997, observou-se que o número de crianças continuava sendo bem menor que o número de matrículas deste ano. Desta forma, partiu-se para 0 emprego de outra variável que melhor se adequasse à situação. A variável escolhida foi a de número 96, que contém as "crianças não alfabetizadas de 0 a 4 anos". Para esta escolha, supôs-se que, como estes valores correspondiam ao ano de 1991, em 1997, essas crianças estariam com idades entre 6 e 10 anos (um ano a menos no erro). Essa medida pareceu mais lógica, principalmente após se ter observado que o número de crianças na escola no ano de 1997 era menor que o total de crianças da variável 96, ao contrário do primeiro caso, onde sobravam vagas ${ }^{2}$. Desta vez, o excedente de crianças desta variável, em relação ao número de matriculados em 97, pôde ser atribuído a fatores, como desistência, mudança, escolha por escolas particulares, etc., o que parecia muito mais sensato.

\section{- Procedimentos Adotados no Estudo de Caso}

Para a aplicação do primeiro modelo citado (modelo de fluxo), como a quantidade de alunos da variável adotada diferia da capacidade ofertada pelas escolas, alguns ajustes de balanceamento para o sistema foram feitos, tornando-os iguais. Isto foi possível a partir de uma redução proporcional de crianças para cada centróide. Essa redistribuição teve que ser feita porque a execução da rotina só se dá com o equilíbrio de oferta e demanda (o ANEXO C mostra os resultados desta redução, com base nas capacidades anterior e posterior à reforma escolar). Os resultados desta redistribuição também podem ser observados no mapa temático da FIGURA 5.5. 
Com os resultados obtidos da rotina de agrupamento, obtiveram-se as "sementes", que indicaram as novas localizações dessas unidades escolares, baseadas na demanda, ou seja, na população agregada (centróides). Essas sementes (pontos iniciais para 0 agrupamento das zonas) foram comparadas aos resultados apresentados no mapa temático criado com esta mesma variável (FIGURA 5.5). Com estes pontos iniciais, partiu-se para 0 distritamento (ou particionamento), que indicou os setores censitários que deveriam ser ligados a cada "semente", levando-se em consideração o relacionamento espacial entre esses setores, num total de dezoito distritos. Adotou-se a criação de dezoito distritos pelo fato de se desejar comparar o atendimento das dezoito escolas da atual situação.

A última rotina, empregada na localização de instalações, fez um comparativo entre os custos médios de percurso antes e após a reforma, assumindo-se, inicialmente, que 0 número de escolas permaneceria constante antes e após esta, isto é, que nenhuma nova escola seria criada. Esta rotina também permitiu avaliar o fechamento de duas escolas, citando-as, no conjunto, como possíveis candidatas a servirem à demanda. Finalmente, pôde-se criar um cenário hipotético, auxiliado pelas rotinas anteriores e também pela comparação com o mapa temático da população agregada empregada.

2 O total de crianças da variável de número 99, já com a correção de crescimento, é de 10.607 crianças, enquanto que, de número 96, é de 12.492 (sem nenhum fator de correção de crescimento). 


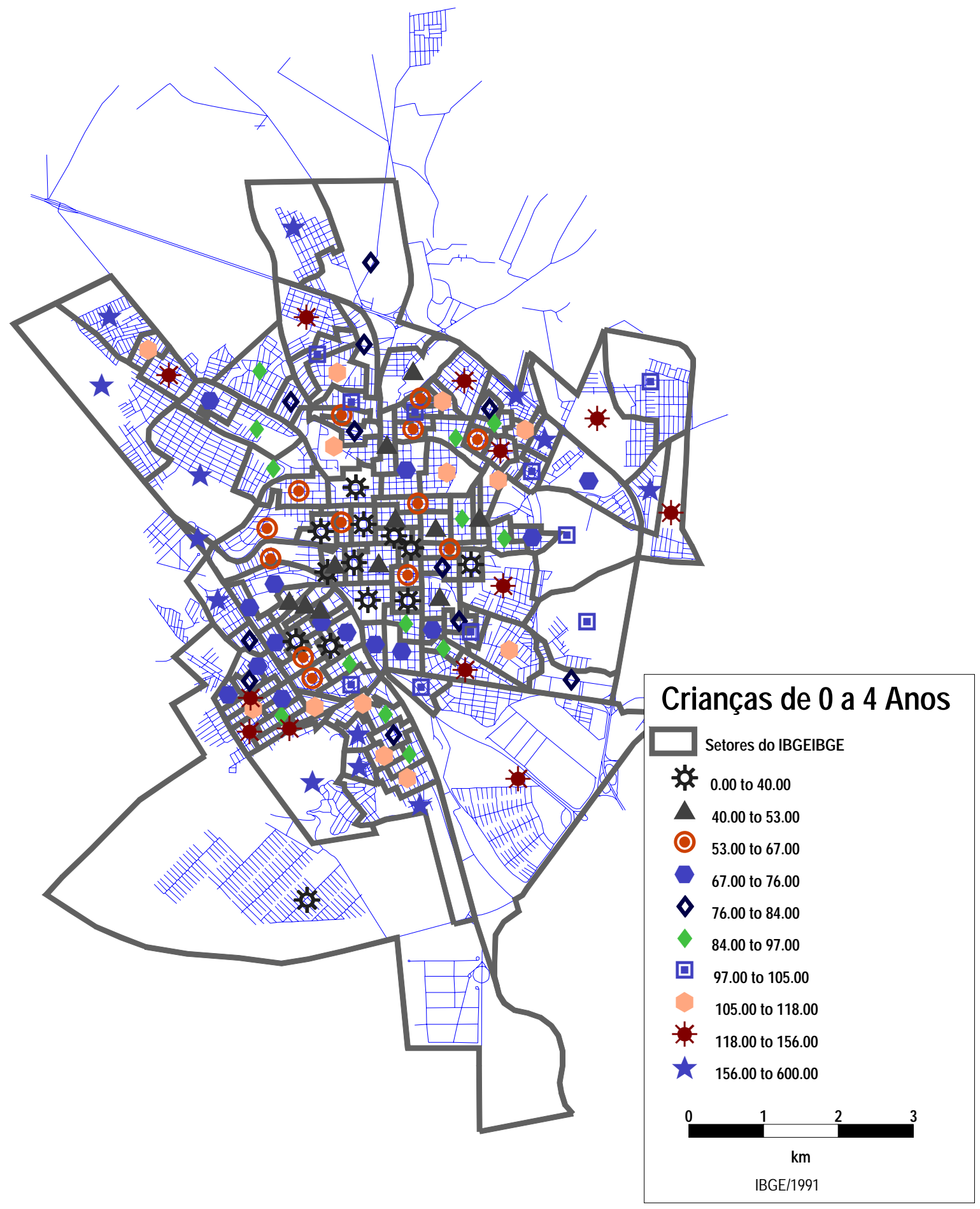

FIGURA 5.5 - Mapa Temático da Variável de nº 96 do IBGE -

"Crianças de 0 a 4 Anos" 


\section{CAPÍTULO 6}

\section{RESULTADOS}

Este capítulo traz os resultados obtidos no estudo de caso mediante a aplicação do método proposto. Primeiramente, serão mostrados os resultados de cada rotina, detalhando-os. Esses resultados também serão dados de forma gráfica, para a melhor compreensão. Conclui-se o capítulo com as análises destes resultados.

\subsection{Resultados da Rotina de Modelos de Fluxo em Rede}

De posse das matrizes de custos (ANEXO D) e de fluxos (ANEXO E), que é fornecida por esta rotina, calculou-se o custo médio de deslocamento através da multiplicação destas. O software possui um módulo específico que também fornece esses resultados. Ao se perceber, no entanto, que os parâmetros estatísticos resultantes não iriam expressar o que se pretendia (parâmetros da demanda observada, não apenas parâmetros estatísticos dos centróides), optou-se pelo trabalho em uma planilha eletrônica. Como os cálculos haviam sido feitos para as duas situações iniciais (antes e após a reforma escolar), obtiveram-se os resultados para ambos os casos, fazendo-se a comparação desses custos. Os gráficos seguintes mostram esses resultados (FIGURAS 6.1 e 6.2)1.

Os custos sem perdas de dados foram de 1,15 e 1,37km antes e depois da reforma, respectivamente, correspondendo a uma variação de cerca de $20 \%$. Salienta-se que a primeira rotina leva em consideração a capacidade real das escolas no sistema (balanceamento feito), o que limita a distribuição, ou seja, pode-se ter aumento nos custos devido a esta restrição na distribuição.

\footnotetext{
${ }^{1}$ No ANEXO F estão as tabelas de distribuição de freqüências destes resultados.
} 


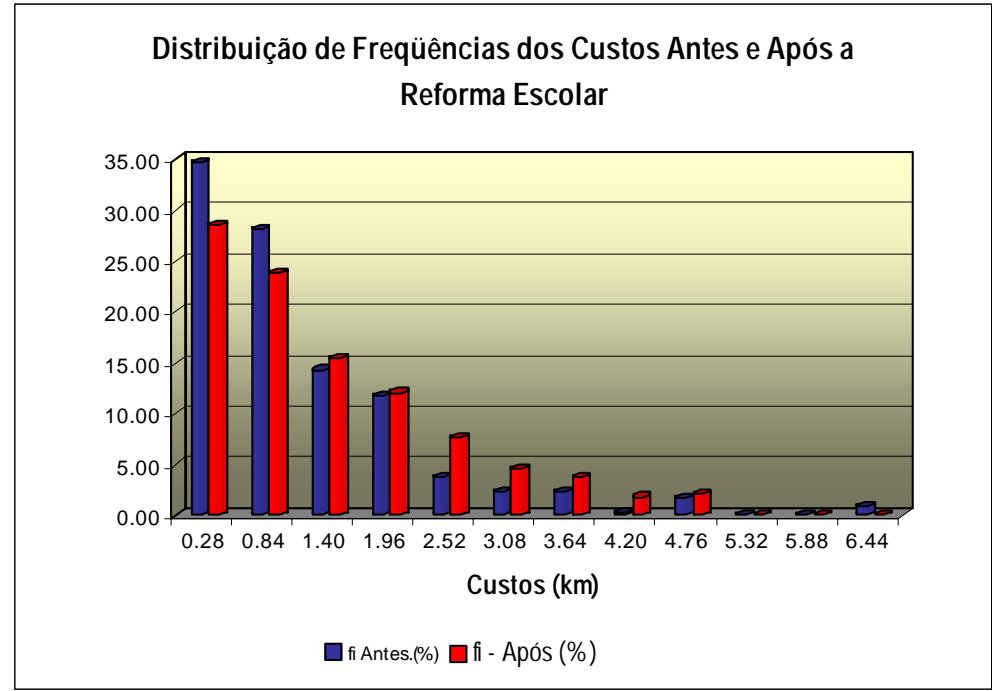

FIGURA 6.1 - Comparação dos Custos de Deslocamento Antes e Após a Reforma Escolar

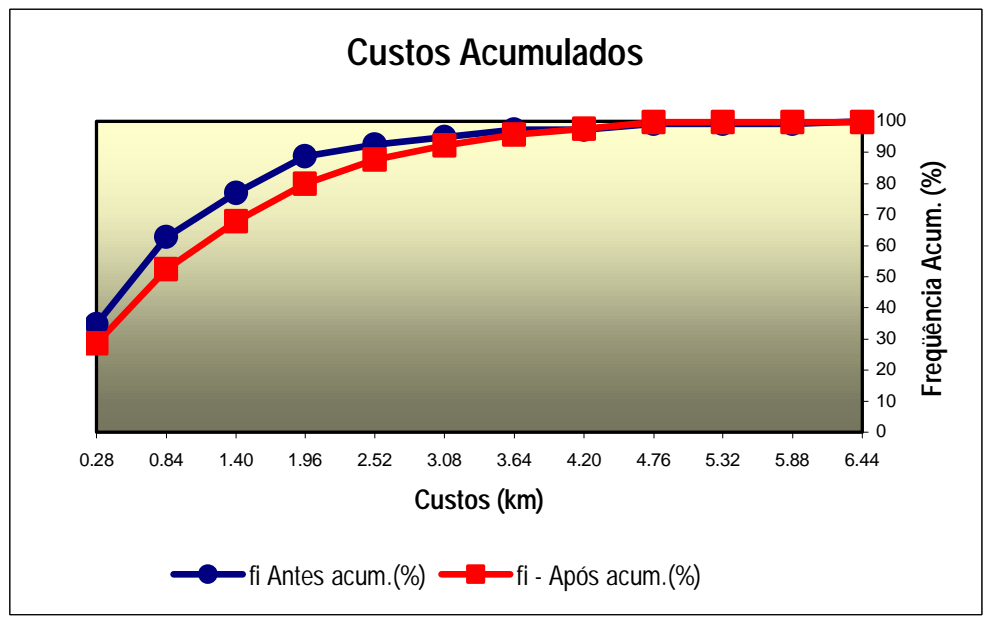

FIGURA 6.2 - Comparação dos Custos Acumulados de Deslocamento Antes e Após a Reforma Escolar 


\subsection{Resultados das Rotina de Agrupamento e Particionamento}

As segunda e terceira rotinas - que tratam de agrupar e particionar grupos com características semelhantes - apresentaram resultados interessantes. Para que se chegasse à escolha dos pontos iniciais (sementes), trabalhou-se com os centróides². Como 0 objetivo era verificar a atual abrangência das escolas, agrupou-se os centróides em 18 blocos (lembra-se que o total de escolas na atualidade é de 18), levando-se em consideração a variável analisada. Estes resultados são mostrados na FIGURA 6.3. Para a melhor visualização das sementes, e para que pudessem ser aplicadas na rotina de particionamento, transferiram-se as mesmas para a camada de áreas dos setores censitários do IBGE, como mostrado na FIGURA 6.4.

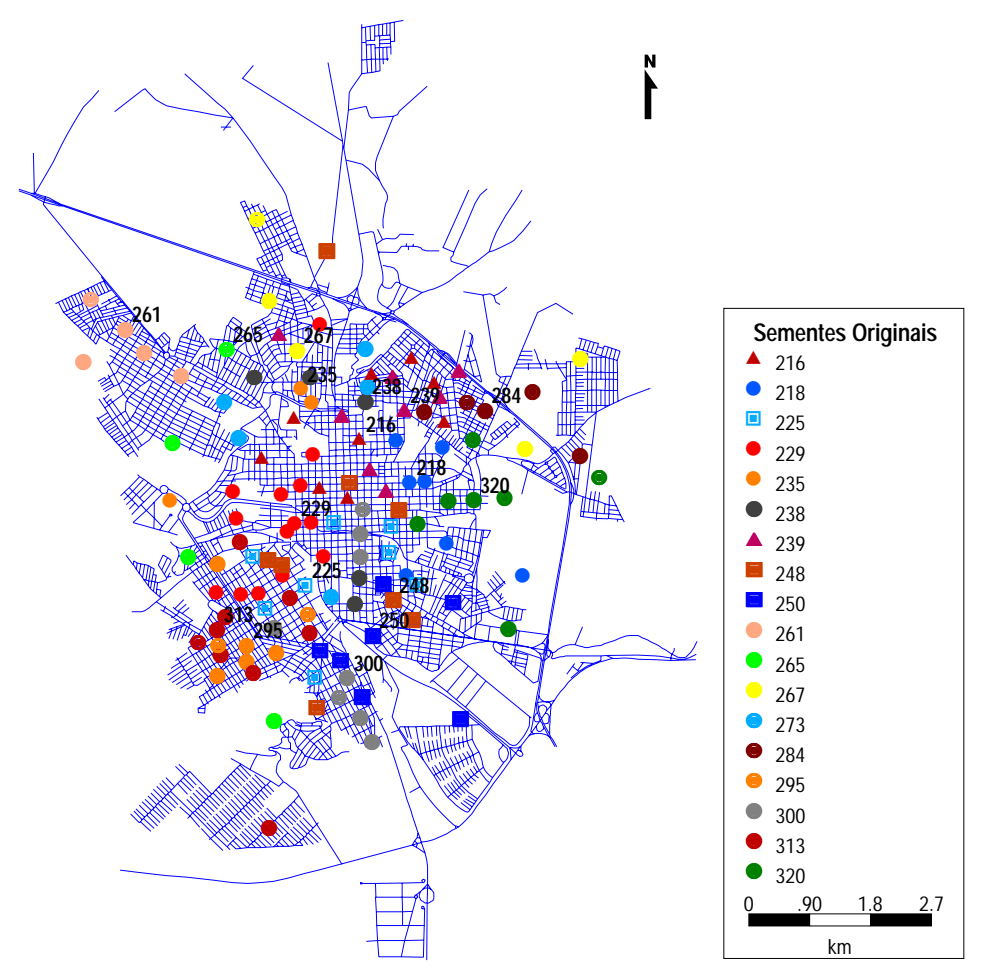

FIGURA 6.3 - Agrupamento dos Centróides Baseado na Variável n० 96 do IBGE (Crianças de 0 a 4 Anos)

2 Também se poderia ter escolhido a camada de áreas do IBGE para gerar essas sementes. 


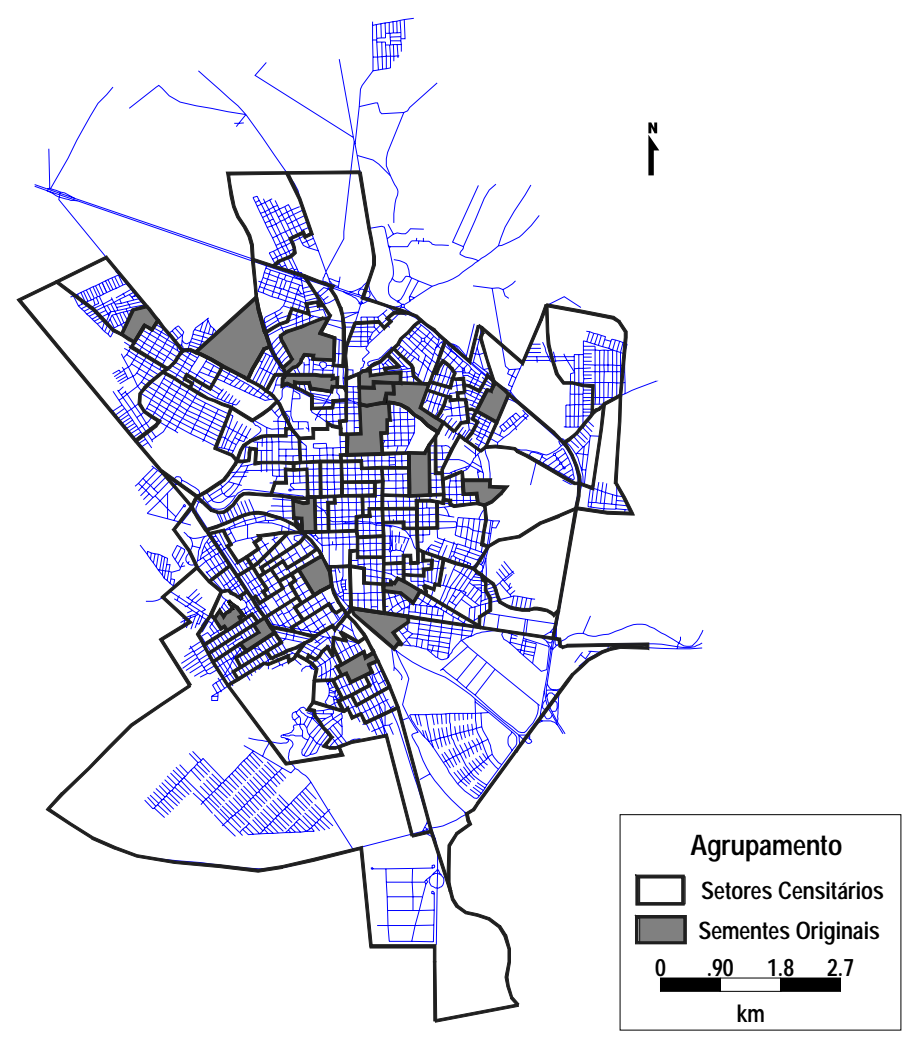

FIGURA 6.4 - Visualização das "Sementes" Geradas pela Rotina de Agrupamento, na Camada de Áreas

Pela FIGURA 6.3, percebe-se que o agrupamento não se deu de forma contígua (a TABELA 4.2 fala da possibilidade de isto acontecer). Além disso, como se observa na FIGURA 6.4, grande parte das sementes estão coladas umas às outras, impossibilitando a aplicação de seus resultados na rotina de particionamento para os setores censitários, de forma direta, já que, para que se tenha a criação de partições menores, as áreas não podem estar tão próximas 3 . O que se atribui à criação destas sementes de maneira tão próxima é 0 fato de estas rotinas levarem em consideração características de compacidade entre as zonas, pois criam grupos os mais compactos possíveis, agrupando características da

\footnotetext{
${ }^{3}$ Chegou-se a esta conclusão após algumas tentativas, onde aparecia uma mensagem na tela, que fazia esta observação.
} 
população analisada, tomando-se por base a distância entre os pontos (centróides). Isso também é observado nas entradas solicitadas pela rotina, que, além do número de partições, pede também a capacidade de cada agrupamento, onde, nesta aplicação, partiu-se de um valor inicial próximo à capacidade média das escolas. Foi-se aumentando este valor de capacidade até 720 , pois para valores menores que este, a rotina não gerava os agrupamentos ${ }^{4}$.

Para que se pudesse aplicar a rotina de particionamento, compararam-se as sementes da rotina anterior com o mapa temático da variável 96 (FIGURA 5.5). Assim, os pontos iniciais (áreas dos setores censitários) passaram a ser aqueles que continham o maior número de crianças de 0 a 4 anos quando as sementes geradas pela rotina de agrupamento se mostravam inadequadas para o software por estarem muito próximas. A FIGURA 6.5 mostra as sementes adotadas para a rotina de particionamento e a FIGURA 6.6 apresenta 0 particionamento feito, usando-se estas sementes como pontos iniciais para estas divisões, 0 qual será valioso para aplicação da última rotina.

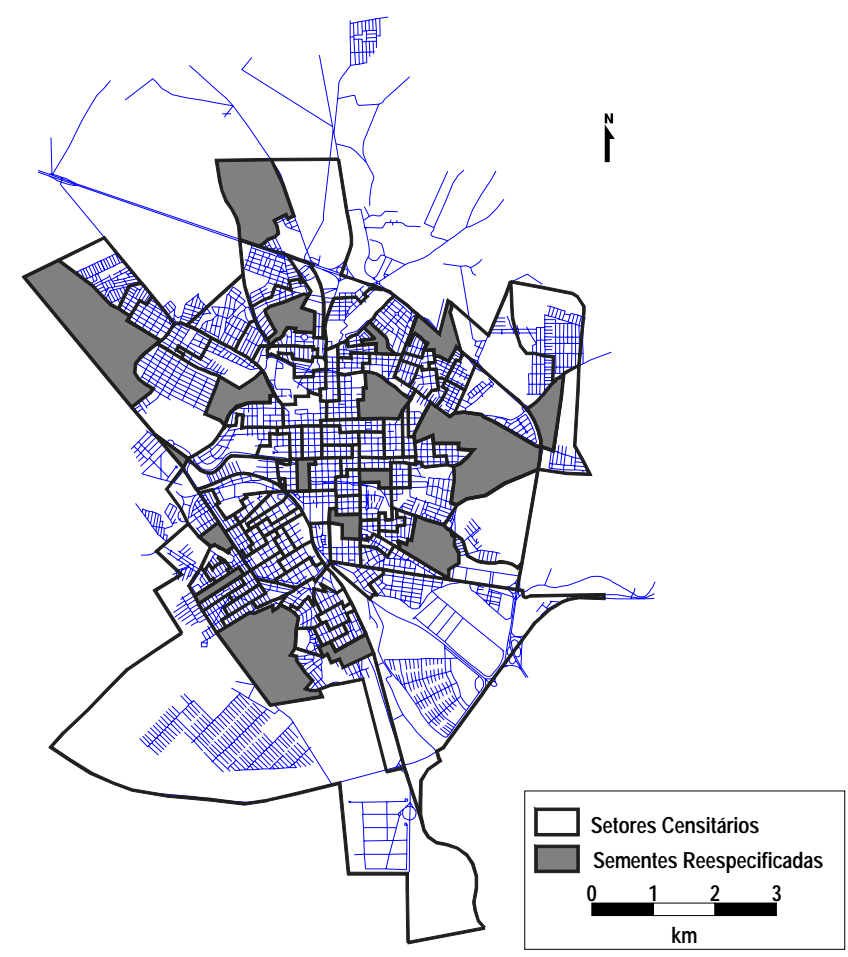

FIGURA 6.5 - Pontos Iniciais Adotados no Particionamento

${ }^{4}$ A média das capacidades da atual situação é de 652 alunos. 


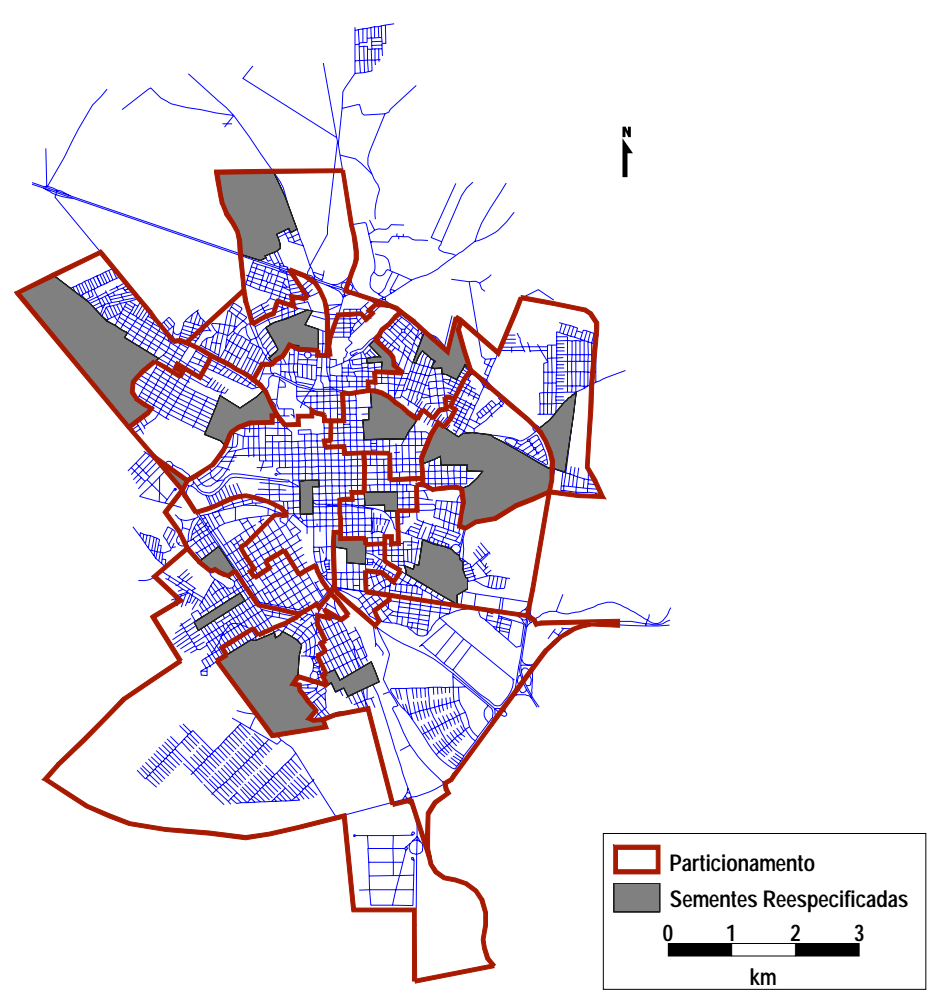

FIGURA 6.6 - Distritamento dos Setores Censitários em 18 Zonas

\subsection{Resultados da Rotina de Localização de Instalações}

Com a aplicação desta última rotina, também pôde-se calcular os custos envolvidos com a realocação dos alunos na reorganização escolar. Esta rotina permitiu ainda a simulação de vários cenários distintos. No primeiro deles, admitiu-se que todas as instalações eram existentes e que nenhuma seria criada, tornando possível os cálculos dos custos de deslocamentos das situações acima mencionadas. Assim, obtiveram-se os valores de 0,67km e 0,91km como custos de deslocamento antes e após a reforma, respectivamente. Aqui, notase um aumento de, aproximadamente, $35 \%$ nas médias de percurso com as mudanças causadas por esta reforma.

Para que se possam tecer alguns comentários sobre o fechamento de duas escolas, utilizou-se novamente a FIGURA 5.5 como primeira medida comparativa. O segundo elemento de comparação foi obtido com o emprego direto da última rotina, por intermédio das 
simulações descritas a seguir. Para que melhor se entendam essas análises, é dada a FIGURA 6.7, que nada mais é que a repetição ampliada da FIGURA 5.2, contendo identificadores para as instalações e mostrando as instalações que foram fechadas com a reorganização.

Fazendo-se uso da última rotina para analisar o fechamento da escola 11, tomaramse as escolas 10 e 11 como candidatas ao cargo de "nova instalação" e as demais como instalações existentes. Fazendo-se 0 uso direto desta rotina, a instalação escolhida, por apresentar menores custos médios de deslocamento para a demanda, foi realmente a escola 10 (FIGURA 6.8). Outra comparação semelhante foi aplicada às escolas 8 e 9. Procedendose do mesmo modo, chegou-se à conclusão de que a melhor instalação seria a candidata número 8 (FIGURA 6.9).

Aplicou-se a última rotina em várias análises. Desta vez, para verificar se houve incoerência na escolha de escolas na reforma escolar. Para isto, analisaram-se duas instalações com características semelhantes de demanda em suas proximidades (observadas a partir do mapa temático da FIGURA 5.5). As escolas escolhidas foram as de número $26 \mathrm{e}$ 28. Com o emprego desta rotina, pôde-se fazer a escolha entre estas duas escolas, colocando-as como candidatas do sistema. Como resposta, obteve-se a escola de número 26. Esta instalação também foi escolhida para continuar atendendo à demanda no caso real, verificando-se, aqui, coerência na escolha.

Segundo informações da Delegacia de Ensino e pela FIGURA 5.5, o aumento de capacidade da escola 1 pareceu correto, já que existe alta demanda nas proximidades. Mesmo assim, é possível que ainda existam crianças próximas a esta escola que não estejam sendo ali atendidas. Neste caso, se a escola número 2 fosse, então, a reorganizada, talvez surtisse melhores resultados que a anterior, pois a quantidade de demanda próxima a esta é maior. Outra vez, para se verificar a hipótese em questão, utilizou-se da última rotina. Procedendo-se da mesma forma, obteve-se a escola de número 2. 


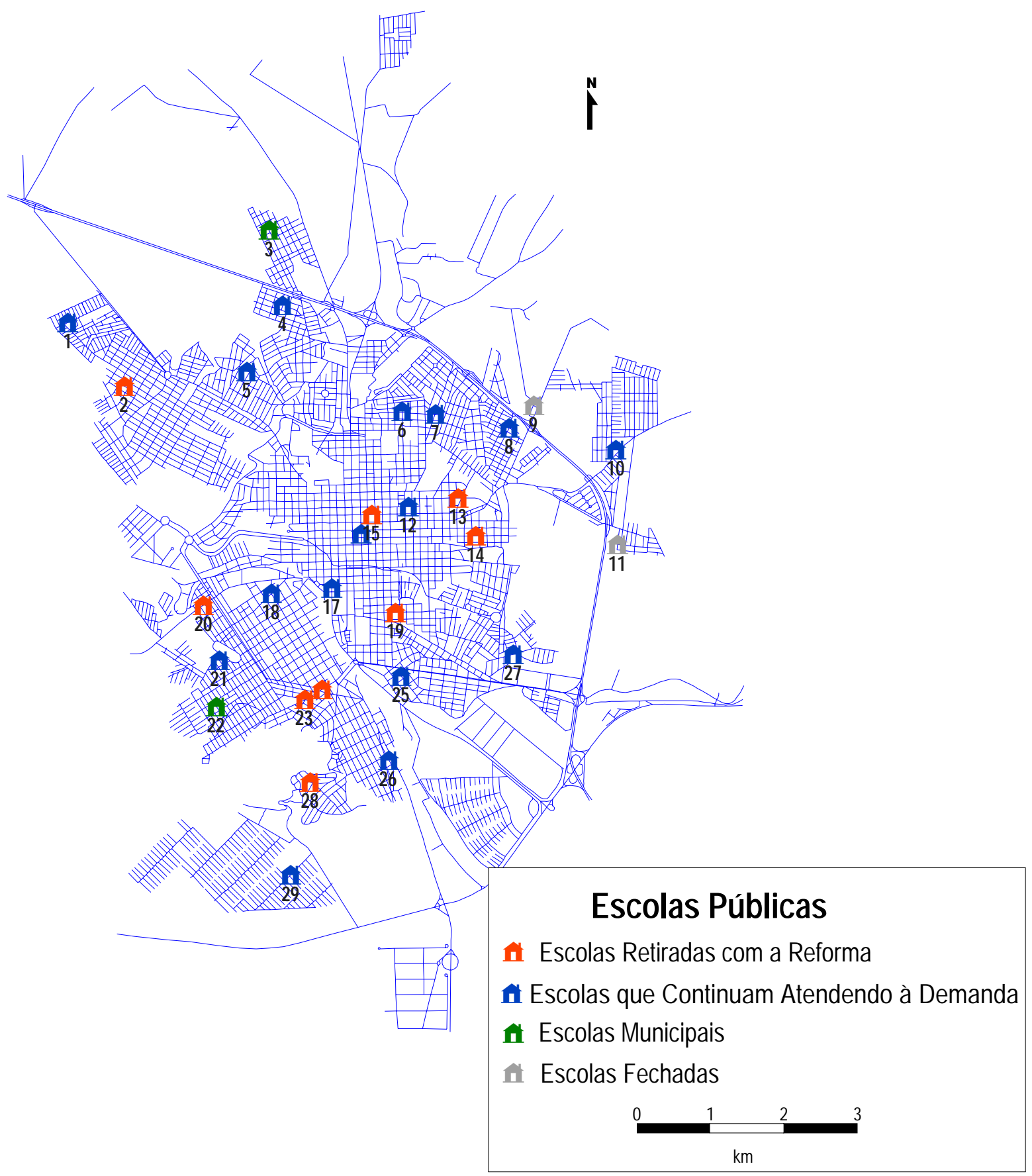

FIGURA 6.7 - Identificação das Escolas Antes e Após a Reorganização Escolar 


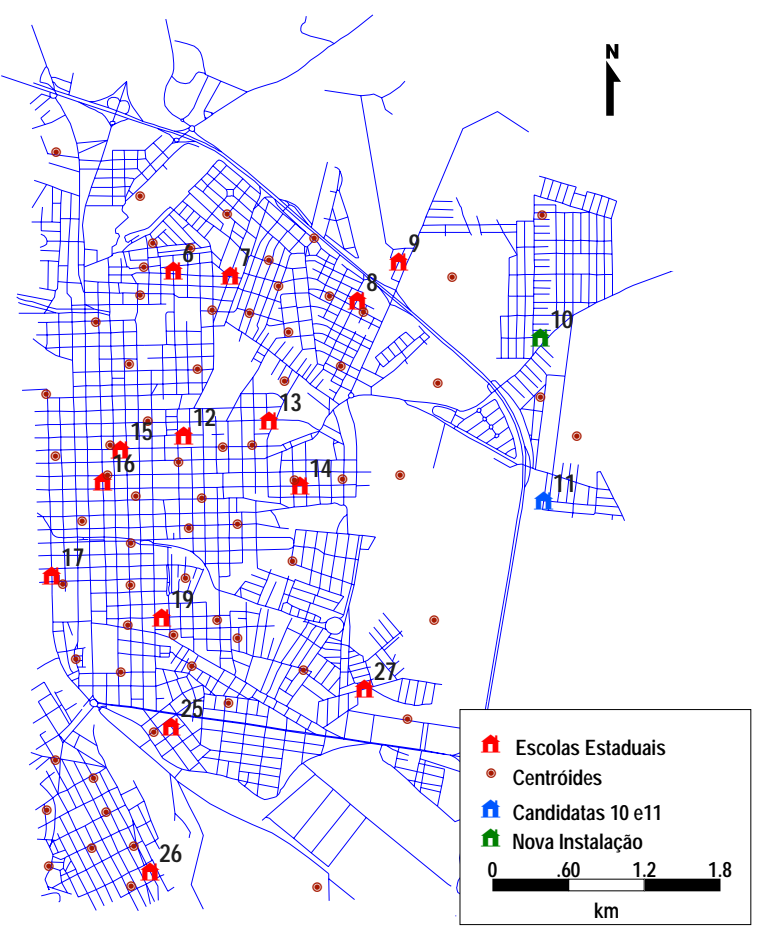

FIGURA 6.8 - Escolha de Melhor Alternativa de Localização. Escolas Candidatas: 10 e 11.

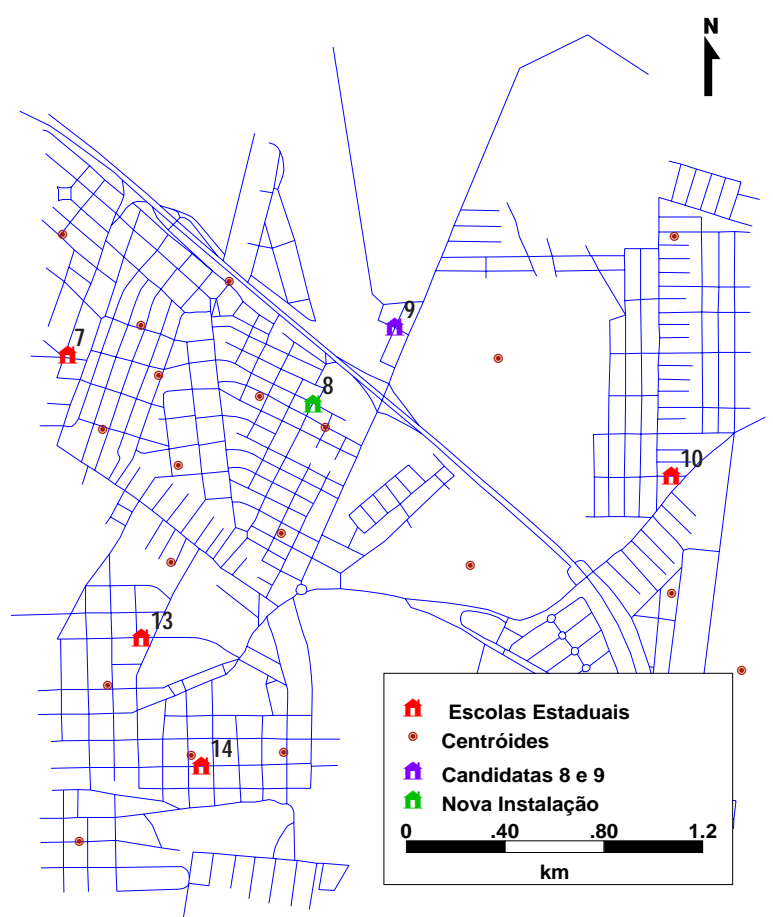

FIGURA 6.9 - Escolha de Melhor Alternativa de Localização. Escolas Candidatas: 8 e 9. 
Vale salientar que a escolha das escolas que concorreram ao cargo de nova instalação (no exemplo citado anteriormente) se baseou no critério adotado pela própria reforma: a demanda deveria se dirigir para a escola mais próxima da que deixara de the atender.

Aplicando-se ainda a última rotina, criou-se um cenário hipotético, representado pelas FIGURAS 6.10 e 6.11, que contém cinco localizações de "escolas candidatas". A escolha dessas localizações tomou por base a distribuição da população analisada (FIGURA 5.5), escolhendo-se locais onde existisse maior número de crianças não atendidas por escolas (a rotina de particionamento serviu de base). Buscava-se respostas para as seguintes questões:

1. Dentre o conjunto, quais as duas melhores localizações para servir à demanda, de maneira a diminuir o custo médio de deslocamento?

2. Quais as duas melhores localizações para diminuir o máximo custo observado?

Em ambos os casos, obtiveram-se as escolas 19 e 23 como resposta, apresentando um custo médio de $0,78 \mathrm{~km}$. Repetiu-se o processo, querendo-se saber qual única e melhor candidata, dentre as cinco, que atendesse aos ítens acima. Neste caso, obteve-se a escola 23 como solução, a qual apresentou custo médio de $0,83 \mathrm{~km}$ para os sistema.

Para finalizar as simulações, avaliou-se o impacto da construção dessas cinco novas instalações na média de deslocamento dos estudantes (dada pela análise de sensibilidade, apresentada na TABELA 6.1 e no gráfico da FIGURA 6.12). Através desta análise, é possível planejar a construção destas instalações de acordo com a média de percurso desejada para o sistema. 


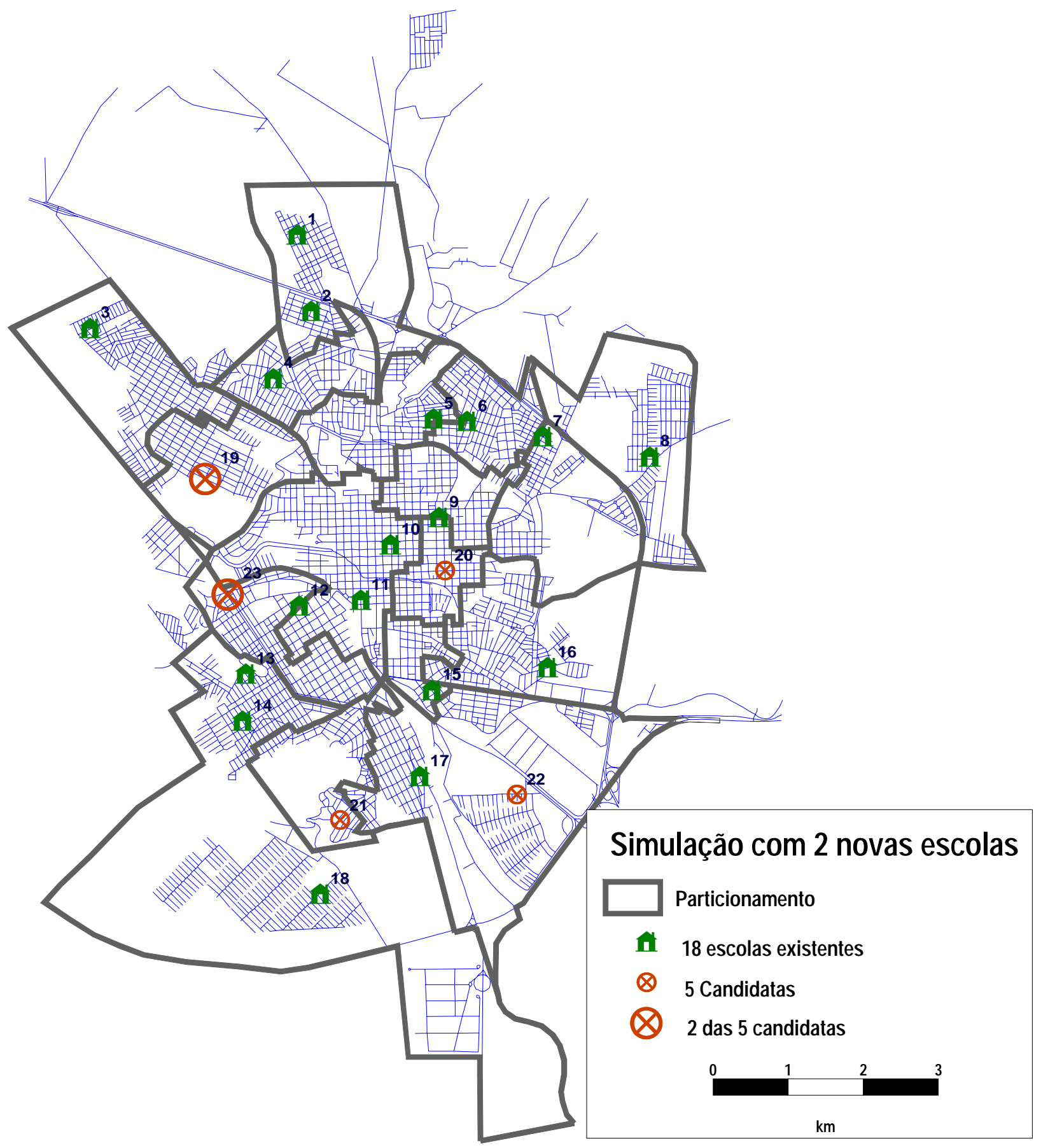

FIGURA 6.10 - Cenário Hipotético - Escolha de duas Melhores Instalações dentre Cinco Candidatas 


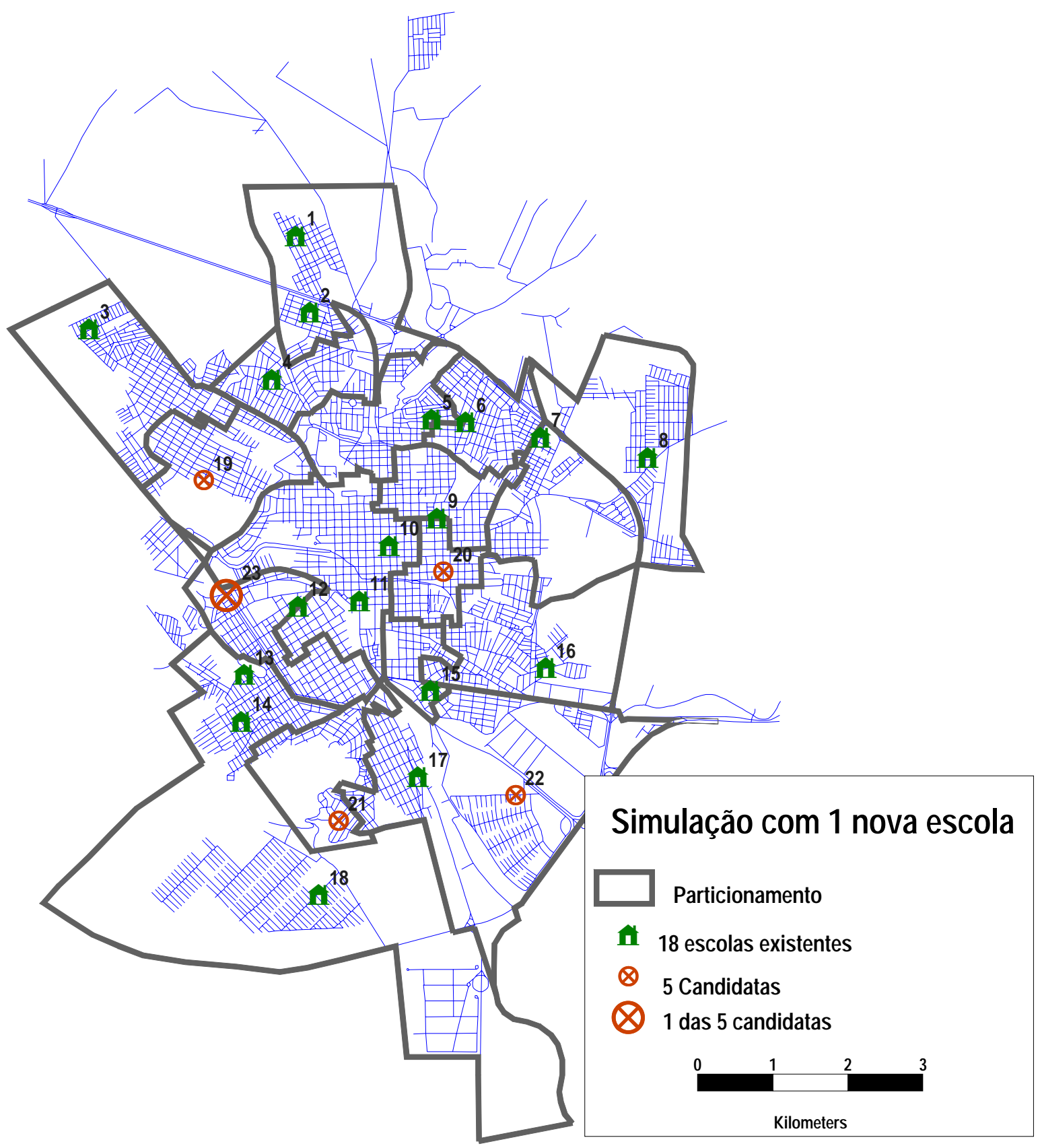

FIGURA 6.11 - Cenário Hipotético - Escolha da Melhor Instalação dentre Cinco Candidatas 
TABELA 6.1 - Análise de Sensibilidade dos Deslocamentos na Construção das Novas Instalações (Cenário Hipotético)

\begin{tabular}{c|c}
\hline \hline No de Instalações Adicionais Escolhidas $^{\text {Percurso Médio (km) }}$ \\
\hline \hline 0 & 0,91 \\
\hline $1^{\star}$ & 0,83 \\
\hline $2^{\star \star}$ & 0,78 \\
\hline $3^{\star \star \star}$ & 0,76 \\
\hline $4^{\star \star \star *}$ & 0,73 \\
\hline 5 & 0,71 \\
\hline \hline
\end{tabular}

${ }^{*}$ ) Apenas a escola 23 foi escolhida.

$\left.{ }^{* *}\right)$ Apenas as escolas 19 e 23 foram escolhidas.

(***) As escolas 19, 22 e 23 foram escolhidas.

$\left.{ }^{(\star \star \star *}\right)$ Apenas a escola de número 20 foi excluída.

\subsection{Análise dos Resultados}

Analisando-se o emprego da primeira rotina, apesar de a mesma supor 0 sistema como ideal (distribuição das crianças de modo a se ter o menor custo para este), essa consideração foi admitida para ambas as situações, de modo que seu resultado mostrou a variação também nesta mesma "base" (sistema ideal antes e após a reforma). Isso faz com que se permita admitir a variação percentual como válida, mesmo não se tendo situações ótimas de distribuição.

Como se previu no início do capítulo, com a aplicação da primeira rotina, pelo fato de se pôr a capacidade das escolas como fator limitante na distribuição dos alunos, o percurso médio tenderia a aumentar. Isso pôde ser comprovado com a aplicação da última rotina, pois a mesma não leva em consideração a capacidade das instalações, considerando, apenas, a variável que se está analisando, distribuindo-a pelas instalações existentes de forma a ofertar o melhor nível de serviço, ou seja, diminuindo os custos de deslocamento entre os pontos de origem e destino. 
Percebeu-se que o emprego da rotina de agrupamento não foi satisfatório para os dados aqui analisados, pois se pretendia aplicá-los diretamente na criação dos distritamentos. Atribui-se essa não-aplicabilidade ao fato de as zonas possuírem características muito diferentes, o que não é citado no manual do software 5 . Teve-se que optar pela análise do mapa temático da variável do IBGE como alternativa de escolha para indicar os pontos iniciais (sementes).

Com a rotina de distritamentos (FIGURA 6.6), vê-se 0 atendimento que hoje é dado à classe de crianças analisada. Analisando-se as FIGURAS 6.6 e 6.7, percebe-se que determinadas zonas possuem mais de uma escola, em detrimento de outras, não atendidas por estas.

Ainda segundo o mapa temático da FIGURA 5.5 e, pela demanda escolar observada, é muito provável ter sido prudente o fechamento da escola número 11, pois apesar de existir uma demanda relativamente alta na região, a escola número 10 foi capaz de absorver a demanda deixada por esta. A mesma observação é feita para a escola 9, também fechada. Observou-se, segundo os dados fornecidos, o aumento de mesma grandeza na capacidade da escola 8, comprovando o recebimento da demanda por esta. Os motivos que as levaram a fechar são, todavia, desconhecidos. Sabe-se, no entanto, que vinham atendendo a baixas demandas.

Pela TABELA 6.1, na análise de sensibilidade da situação hipotética criada, percebese que, em alguns casos (de 2 escolas adicionais para 3, por exemplo), a construção de mais uma instalação não implica em uma redução significativa dos custos de deslocamentos. Assim, ao se fazer esse tipo de análise, deve-se proceder à escolha do "número ótimo de instalações", de modo a satisfazer aos custos de deslocamentos pré-definidos, bem como 0 de se evitar gastos com a construção de instalações desnecessárias - do ponto de vista dos benefícios significativos de redução de deslocamentos. Neste caso, o aumento na capacidade de alguma outra instalação (já existente no sistema) pode se apresentar como melhor solução alternativa.

${ }^{5}$ O manual apenas cita a possibilidade da criação de grupos não contíguos, não explicitando que, para este caso, não se deva usar os resultados desta rotina na outra, de distritamento. 
Enfatiza-se, aqui, o desconhecimento de quaisquer outros fatores, que não os de capacidade e localização das escolas, no emprego de dados agregados nesta avaliação. Uma maneira de comprovar a validação desta pesquisa seria a aplicação do mesmo método para demandas de diferentes níveis de escolaridade. Como exemplo disto, reportando-se ao caso da escola número 2 (FIGURA 6.7), admitindo-se este estudo como aplicável, a melhor solução talvez fosse o aumento de sua capacidade ou a construção de uma nova escola para atender a outro tipo de demanda, se fosse o caso. Como se observou, a escola que passou a atender à demanda em estudo foi a escola 1, cuja localização apresenta menores índices de demanda que a de número 2. Também é válido relembrar os procedimentos adotados pela reorganização, apresentados no terceiro capítulo (um deles diz respeito à infra-estrutura da escola como parâmetro de distribuição dos níveis de demanda). 


\section{CAPÍTULO 7}

\section{CONCLUSÕES E RECOMENDAÇÕES}

Pode-se afirmar que este trabalho atingiu os objetivos propostos, uma vez que foi possível se fazer as análises comparativas dos deslocamentos da demanda estudada com a reforma escolar, e de avaliar novos possíveis arranjos alternativos de localização destas escolas, de forma a melhor atender às crianças que se utilizam deste serviço.

O emprego das ferramentas apresentadas neste trabalho pode ser muito útil como suporte a decisões no planejamento de distribuição espacial das escolas, não se limitando apenas a estas, já que se poderia aplicar o mesmo método, por exemplo, na distribuição de postos de saúde, de agências de correios, ou quaisquer outros serviços que atendessem a outros tipos de demanda. De maneira geral, é um ferramental valioso no planejamento urbano.

Este estudo aplicou o uso de dados agregados para que se pudesse proceder a análises. Caso se tivessem as reais origens de toda a demanda, o uso de dados agregados não se faria mais necessário. Como conseqüência, ter-se-ia apenas a corroboração ou a refutação do método apresentado neste trabalho, bem como de seus resultados.

Em todo caso, uma contribuição do trabalho, que não deixa transparecer dúvidas, foi o fato de se ter observado o aumento superior a $20 \%$ nos percursos de caminhada das crianças após a reorganização escolar. Pode-se afirmar que esta reforma escolar foi positiva do ponto de vista econômico, já que conseguiu diminuir gastos com a repetência anual (embora não sejam, neste trabalho, questionados os métodos educativos aplicados), todavia, apresentou seu lado negativo sob a forma de aumento médio considerável nos 
deslocamentos para este mesmo fim. Esse aumento, no entanto, poderia ter sido minimizado se ferramentas, como as que aqui foram apresentadas (um software específico de SIG para transportes), fossem utilizadas no planejamento da reorganização. Isso ficou claro ao se utilizar a quarta rotina do software, na qual não se impõe limite de capacidade para as escolas. Nesse caso, obtêm-se valores médios de deslocamentos bastante inferiores aos valores observados inicialmente. Poderia ter-se alterações das capacidades das escolas de forma compatível à demanda atendida, bem como uma distribuição otimizadora dessas instalações, também compatível com a demanda a ser servida, de modo a apresentar melhores custos de deslocamentos. Ressalta-se, no entanto, que a média dos percursos analisados está dentro de valores aceitáveis, tanto aqui, como em outros países.

Uma aplicação prática, que poderia ser feita com a localização exata dos alunos, é a de se ter, dentro de uma mesma região, possíveis localizações de escolas. A escolha definitiva da nova escola tomaria a origem dos alunos como referencial. A localização que apresentasse, por exemplo, o menor custo médio seria a vencedora. Outro exemplo de aplicação (observado neste trabalho com dados agregados) foi o emprego deste método na escolha da escola de número 2 no lugar da, reorganizada, número 1. Se recursos, como os que aqui foram apresentados, tivessem sido adotados na reforma escolar, é muito provável que gastos de deslocamentos fossem minimizados. Se adotados, todavia, outras considerações deveriam ser aliadas às apresentadas anteriormente, dentre elas a própria capacidade das instalações e uma possível flexibilidade desta capacidade, para que melhor se distribuíssem estas instalações na área urbana. Informações de percursos máximos desejáveis também seriam parâmetros avaliados nesse planejamento.

Para estudos posteriores, sugere-se a repetição dos procedimentos apresentados no método desenvolvido, desta vez, com dados desagregados ? caso haja a cessão destes por parte das instituições responsáveis. Também como sugestão, deixa-se a correção das distâncias que não se encontram em trechos planos. Os aclives e declives não proporcionam o mesmo nível de esforço para um mesmo percurso (isso é particularmente importante para cidades de terrenos muito acidentados, como é o caso de São Carlos). Para isso, pode-se criar um fator de correção para estes trechos dentro dos próprios SIGs. Isto tornará a comparação de percursos mais realista. 
Lamenta-se a inexistência de uma política de cooperação entre algumas instituições públicas, as quais detêm informações reais das demandas que servem. Devido a isto, a aquisição de dados se torna morosa e, neste caso, sem o retorno esperado. Seria interessante que os representantes destes órgãos tivessem a percepção da troca de informações como ponto de partida para novos estudos e, a partir destes, a determinação de novas tecnologias e métodos a serem aplicados, na prática, buscando melhor servir à comunidade, diminuindo, desta forma, gastos, muitas vezes, desnecessários. Louve-se, aqui, a atitude de funcionários de órgãos públicos, na cidade de São Carlos, que se mostraram sempre dispostos a colaborar com a pesquisa, na esperança de melhorar o sistema. 0 fato de não se ter obtido as informações desejadas não invalida o trabalho aqui desenvolvido, porém não o deixa ser preciso em seus resultados. 


\section{REFERÊNCIAS BIBLIOGRÁFICAS}

ALMEIDA, L. M. W.; GONÇALVES, M. B. (1996). Um Estudo Sobre Modelos de Localização e Alocação e Critérios de Eqüidade para os Serviços Públicos. Anais do $X$ Congresso de Pesquisa e Ensino em Transportes, ANPET, Brasília-DF, vol. 1, p. 189-197.

ALMEIDA, M. F. B; SANCHES, S. P. (1997). Roteirização de Veículos para o Transporte de Alunos da Zona Rural com Auxílio de um SIG. Dissertações em Andamento do XI Congresso de Pesquisa e Ensino em Transportes-ANPET, Rio de Janeiro-RJ, p. 45-48.

AMORIM, A.; SILVA, R S. (1994). Cadastro Multifinalitário Urbano Georeferenciado como Instrumento para a Administração Pública em Municípios de Médio Porte. Anais do 10 Congresso Brasileiro de Cadastro Técnico Multifinalitário, Florianópolis-SC, p. 100-105.

APEOESP (1989). Associação dos Professores do Ensino Oficial do Estado de São Paulo. Revista de Educação, no 4, p. 31-33.

APEOESP (1996). Sindicato dos Professores do Ensino Oficial do Estado de São Paulo. Jornal no 221.

AZANHA, J. M. P. (1992). Políticas e Planos de Educação no Brasil: Alguns Pontos para Reflexão. Fundação Carlos Chagas. Cadernos de Pesquisa, no 85, Editora Cortez, São Paulo, 1993, p. 70-78.

BASTOS, M. M. de M. (1995). Parte I: Industrialização Brasileira: Ascensão e Crise de um Modelo. Transportes I? Síntese do Curso em Engenharia Civil, Universidade Federal do Ceará, Fortaleza-CE, p. 3-19.

BRAVO F., F.; CERDA T, J. (1995). Tecnologia SIG Aplicada a Sistemas de Transportes. Actas VII Congreso Chileno de Ingenieria de Transporte, Santiago, Chile.

BUZAY, G. D.; DURÁN, D. (1997). Enseñar e Investigar con Sistemas de linformación Geográfica. $1^{\text {a }}$ ed. Buenos Aires, Argentina. Toquel.

CALIPER (1996). TransCAD - Transportation GIS Software. Routing and Logistics with TransCAD. Caliper Corporation, Version 3.0 for use with Microsoft Windows. 
CÂMARA, G. (1994). Anatomia de um SIG. Revista. Revista Fator GIS, Sagres Editora, $\mathrm{n}^{0}$ 04, p. 11-15.

CÂMARA, G. et al. (1997). Anatomia de Sistemas de Informação Geográfica. Instituto de Computação, IMECC-UNICAMP, Campinas-SP.

CENTRO DO PROFESSORADO PAULISTA (1992). Apostila de Conhecimentos Gerais de Educação, São Paulo, vol. 1, p. 16-25.

CONSTITUÇÃO FEDERAL (1988). Constituição da República Federativa do Brasil, Trabalhista,1988. Art. 30.

COVAS, M. (1996). Governo do Estado de São Paulo. Revista Você Sabia?, Secretaria de Governo e Gestão Estratégica, Imprensa Oficial do Estado, sem no.

DIÁRIO OFICIAL DO ESTADO de 5/12/95, Seção I, p. 5.

DICIONÁRIO AURÉLIO (1993). 3a Edição Revista e Ampliada, 7a impressão, Editora Nova Fronteira, Rio de Janeiro.

DIMENSTEIN (1995). Jornal Folha de São Paulo, 03/12/95.

ESTATUTO DA CRIANÇA E DO ADOLESCENTE (1993). Ministério da Saúde/Ministério da Criança - Governo do Brasil, Artigos 3e 53, p. 13.

FERRARI, R. (1997). Viagem ao SIG, Sagres Editora, Curitiba-PR.

FONSECA, F.T.; ZUPPO, C. A. (1996). School Pre-registration and Student Allocation. Anais da $32^{\text {nd }}$ Annual Conference of the Urban and Regional Information Systems Association, Milwaukee, Estados Unidos.

GEIPOT (1995). Empresa Brasileira de Planejamento de Transportes. Avaliação Preliminar do Transporte Rural - Destaque para o Segmento Escolar, Ministério dos Transportes, Brasília-DF.

HERNÁNDEZ, A. G. (1990). El Cadastro: Elaboracion y Uso. Ciudad y Territorio, vol. 84, p. 71-91.

HSIAO, S.; STERLING, J. (1992). Use of Geographic Information System for Transportation Data Analysis. Microcomputers in Transportation, American Society of Civil Engineers, Nova lorque, p. 94-102.

HUXHOLD, W. E. (1991). An Introduction to Urban Geographic Information Systems, Oxford University Press, Inglaterra. 
KAGAN, H. et al. (1992). Uso de Sistemas de Informações Geográficas no Planejamento de Transportes. Anais do VI Congresso de Pesquisa e Ensino em Transportes-ANPET, Rio de Janeiro-RJ, vol. II, p. 894-909.

LANGFORD, H.; LEWIS, S. (1995). A Comparison of the GIS-T Market in Europe and the UK. The 23rd European Transport Forum, Inglaterra, p. 73-84.

LEONARDI, G. (1981). A Unifying Framework for Public Facility Location Problems ? Part 1: A Critical Overview and Some Unsolved Problems. Environment and Planning A, Holanda, vol. 13, pp. 1001-1024.

LUCKESI, C. C. (1992). Planejamento e Avaliação na Escola: Articulação e Necessária Determinação Ideológica. Revista Idéias, np 15, Secretaria de Estado da Educação, Governo do Estado de São Paulo, p. 115-125.

MALLIO, A. B. (1992). Ensino: As Abordagens do Processo. Formação Geral, Governo de São Paulo, CDU:37.13(81), p. 50-56.

MALLIO, A. B. e PALMA FILHO, J. C. (1992). Estado, Educação e Desenvolvimento Econômico. Formação Geral, Governo de São Paulo, CDU:37.13(81), p. 10-12.

MELLO, G. N. de (1985). Educação e Transição Democrática. Coleção Polêmicas do Nosso Tempo. Cortez/Autores Associados, São Paulo, p. 13-43.

NEUBAUER DA SILVA, R; MELLO, G. N. (1991). A Qualidade do Sistema de Ensino e a Autonomia da Escola. Estudos Avançados, no 5, USP.

NOVAES, A. G.; ROSSETO, C. F. (1993). Localização de Depósitos numa Rede Logística com Auxílio de GIS. Anais do 7 Congresso de Pesquisa e Ensino em Transportes, ANPET, São Paulo-SP, vol. 2, p. 605-616.

OPPONG, J. R.; HODGSON, M. J. (1994). Spatial Accessibility to Health Care Facilities. Suhun District, Ghana. Professional Geographer, Cambridge, p. 199-209.

PAIVA, H. (1993). Citação feita pela Revista Nova Escola, no 64, p. 10.

PALMA FILHO, J. C. (1992). Educação, Ideologia e Contra-Ideologia. Formação Geral, Governo de São Paulo, CDU:37.13(81), p. 18-23.

PAREDES, E. A. (1994). Sistema de Informação Geográfica (SIG) - Princípios e Aplicações (Geoprocessamento), Editora Érica, São Paulo-SP. 
PEREÑA, J. G. (1990). El Catastro y los Sistemas de Informacion Territorial de Ambito Local. Ciudad y Territorio, vol. 84, p. 93-99.

PIMENTEL, F. L. et al. (1994). Uma Visão Sobre SIG. Anais do VIII Congresso de Pesquisa e Ensino em Transportes-ANPET, Recife-PE, vol. 2, p. 517-528.

POPPOVIC, A. M. (1983). Enfrentando o Fracasso Escolar, in Democratização e Ensino de Primeiro Grau. Revista ANDE (Associação Nacional de Educação), Editora Cortez, São Paulo, p. 6-10.

RESENDE, E. (1993). Citação feita pela Revista Nova Escola, no 64, p. 10.

RODRIGUES, M. (1993). Geoprocessamento: Um Retrato Atual. Revista Fator GIS, Sagres Editora, $n^{0}$ 02, p. 20-23.

RODRIGUES, N. (1992). Modernidade e Educação: Tópicos para Discussão. Revista Idéias, no 15, Secretaria de Estado da Educação, Governo do Estado de São Paulo, p. 97-114.

ROMÃO, J. E. (1994). A Revolução Silenciosa. Nova Escola, no 73, p. 10-19.

ROSSETO, C. F.; CUNHA, C. B. (1994). A Aplicação do Geoprocessamento na Roteirização de Veículos. Anais do GIS Brasil 94 - Curitiba-PR, pp. 35-44.

SECRETARIA DE ESTADO DA EDUCAÇÃO DE SÃO PAULO (1995). Jornal Escola Agora Aprendendo Sempre, Ano I, $\mathrm{n}^{0} 2$.

SECRETARIA DE ESTADO DA EDUCAÇÃO DE SÃO PAULO (1996a). Jornal Escola Agora Aprendendo Sempre, Ano II, nº4.

SECRETARIA DE ESTADO DA EDUCAÇÃO DE SÃO PAULO (1996b). Jornal Escola Agora Aprendendo Sempre, Ano II, n6.

SECRETARIA DE ESTADO DA EDUCAÇÃO DE SÃO PAULO (1996c). Jornal Escola Agora Aprendendo Sempre, Ano II, n³.

SECRETARIA DE ESTADO DA EDUCAÇÃO DE SÃO PAULO (1997). Jornal Escola Agora Aprendendo Sempre, Ano II, nº11.

SECRETARIA DE GOVERNO E GESTÃO ESTRATÉGICA (1996). Governo do Estado de São Paulo, Revista Você Sabia?, Secretaria de Governo e Gestão Estratégica, Imprensa Oficial do Estado, s/ no.

SILVA, A. N. R; MELO, J. J. de O.; BRONDINO, N. C. M. (1997). Uma Introdução ao Planejamento de Transportes com Sistemas de Informação Geográfica, Publicado pela EESC-USP, São Carlos-SP. 
SILVA, A. N. R. ; WAERDEN, P. (1997). First Steps with a Geographic Information System for Transportation, São Francisco, Ribeirão Preto.

SILVA, A. N. R.; LOTTI, C. P.; MARGARIDO, S. A; PAMPOLHA, V. M. P. (1996). Quem não tem Tiger... Revista Fator GIS, Curitiba-PR, 4 (14): 18-19.

SINDICATO DE ESPECIALISTAS DE EDUCAÇÃO DO MAGISTÉRIO OFICIAL DO ESTADO DE SÃO PAULO (1996a). Jornal O DIRETOR UDEMO, no 4.

SINDICATO DE ESPECIALISTAS DE EDUCAÇÃO DO MAGISTÉRIO OFICIAL DO ESTADO DE SÃO PAULO (1996b). Jornal O DIRETOR UDEMO, São Paulo, boletim especial de nov/96.

SOUZA E SILVA, M. A. S. (1992). A Revolução Silenciosa. Nova Escola, n 73, p. 10-19.

STEVENSON, W. J. (1981). Estatística Aplicada à Administração, Câmara Brasileira do Livro, São Paulo.

TEIXEIRA, A L. A.; MORETTI, E.; CHRISTOFOLETTI, A. (1992). Introdução aos Sistemas de Informação Geográfica. Edição do Autor, Rio Claro-SP.

THORNTHWAITE, S. e PETTITT, T. (1995). The Use of GIS in Planning Home to School Transport Provision. The 23rd European Transport Forum, Inglaterra, pp. 37-44.

THORNTHWAITE, S. (1994). School Transport - The Comprehensive Guide, TAS Publication, Inglaterra.

V. MALLIO, L. A. (1992). Magistério de 10 Grau: da Competência Técnica ao Compromisso Político. Formação Geral, Governo de São Paulo, CDU:37.13(81), p. 13-23.

V. MALLIO, L. A. e PALMA FILHO, J. C. (1992?). Educação e Desenvolvimento Social no Brasil, in Formação Geral, Governo de São Paulo, CDU:37.13(81), p. 5-9.

VALDEPEÑA, J. R. (1994). SIG na América Latina. Revista Fator GIS, Sagres Editora, nº 05, p. 8-9.

VASCONCELLOS, E. A. (1997). O Resgate de um Tema Perdido. Revista dos Transportes Públicos, ANTP (Associação Nacional de Transportes Públicos), $2^{0}$ Trim. 97, p. 31-48.

VEJA (1997). Editora Abril, Edição 1502, no 26, 02/06/1997, p.96-97. 
VIVIANI, E., SÓRIA, M. H. A.; SILVA, A. N. R. (1994). Gerenciamento de Vias NãoPavimentadas e a Utilização de Sistema de Informação Geográfica (SIG). Anais do $1^{0}$ Congresso Brasileiro de Cadastro Técnico Multifinalitário, Florianópolis-SC, p. 118-126.

WARDE, M. J. (1992). Considerações Sobre a Autonomia da Escola. Fundação para 0 Desenvolvimento da Educação, Série Idéias, no 15, p. 83-96. 